Çukurova Üniversitesi Eğitim Fakültesi Dergisi

Vol:47 No:1 Sayfa:60-108

www.cufej.com

\title{
Quantitative Reasoning: Reflections on Solving Real-World Problems
}

\section{Dilek TANIŞLI ${ }^{\mathrm{a}^{*}}$, Mehmet DUR $^{\mathrm{b}}$}

${ }^{a}$ Anadolu Üniversitesi, Eğitim Fakültesi, Eskişehir/Türkiye

${ }^{b}$ Milli Eğitim Bakanlığı, Eskişehir/Türkiye

\section{Article Info}

DOI: $10.14812 /$ cuefd.398406

Article history:

Received 25.02.2018

Revised 20.03.2018

Accepted 22.03.2018

Keywords:

Clinical interview,

Mathematics ecucation,

Quantitative reasoning,

Secondary school,

Problem solving.

\begin{abstract}
The purpose of this research is to determine the role of quantitative reasoning in the problem-solving process of the two students who go in sixth grade of secondary school. In this research, in which the qualitative research method is adopted, there were five weeks of instruction carried out with students who go in sixth grade of secondary school in order to determine how the development of quantitative reasoning led to a change in problem-solving ability. Clinical interviews were conducted with students selected as the focus at the beginning and end of the process. Data from this study were also collected from the data of two students who were interviewed clinically. In the analysis of the data, the thematic analysis method was used. As a result of the research, it was observed at the interviews that the quantitative reasoning skills of the two students, who had low quantitative reasoning ability at the preliminary talks, changed at the end of the teaching process. It has been determined that this change is reflected in the problem solving process of the students and that they are also successful in the problems with medium and high difficulty level according to the pre-teaching. In this process, it has been observed that students can solve problems more than one way, choose appropriate strategies for their problem situations and also increase the use of visual representation which has an effective place to do quantitative reasoning.
\end{abstract}

\section{Nicel Muhakeme: Gerçek Yaşam Problemlerinin Çözüm Sürecinden Yansımalar}

Makale Bilgisi

DOI: $10.14812 /$ cuefd.398406

Makale Geçmişi:

Geliş 25.02.2018

Düzeltme 20.03.2018

Kabul 22.03.2018

Anahtar Kelimeler: Klinik görüşme,

Matematik eğitimi,

Nicel muhakeme,

Ortaokul öğrencileri,

Problem çözme.

\section{Öz}

$\mathrm{Bu}$ araştırmanın amacı, ortaokul altıncı sınıfa devam eden iki öğrencinin nicel muhakeme gelişimlerinin problem çözme sürecindeki rolünü belirlemektir. Nitel araştırma yönteminin benimsendiği bu araştırmada nicel muhakeme gelişiminin problem çözme becerisinde nasıl bir değişime yol açtığını belirleyebilmek için altıncı sınıfa devam eden öğrenciler ile beş hafta süren bir öğretim gerçekleştirilmiştir. Bu sürecin başında ve sonunda odak olarak seçilen öğrenciler ile de klinik görüşmeler yapılmıştır. Bu araştırmanın verileri de klinik görüşme yapılan iki öğrencinin verilerinden toplanmıştır. Araştırmada verilerin analizinde tematik analiz yöntemi kullanılmıştır. Araştırma sonucunda ön görüşmelerde düşük nicel muhakeme becerisine sahip olan iki öğrencinin öğretim süreci sonunda yapılan görüşmelerde nicel muhakeme becerilerinin gözle görülür şekilde değiştiği gözlenmiştir. Bu değişimin öğrencilerin problem çözme süreçlerine yansıdığı ve öğretim öncesine göre güçlük düzeyi orta ve yüksek olan problemlerde de başarılı oldukları, problem durumlarına uygun stratejileri seçebildikleri gözlenmiş, ayrıca nicel muhakeme yapabilmede etkin

*Author: dtanisli@anadolu.edu.tr

*This study was derived from the master's thesis written by Mehmet Dur under the supervision of Assoc. Prof. Dilek Tanışlı. 


\section{Introduction}

A mathematical problem can generally be solved arithmetically or algebraically, depending on the age and grade levels. An arithmetic solution includes showing the numbers that are present in the problem, understanding the relations between these numbers, applying the correct arithmetic operation between the appropriate pairs of numbers depending on these relations, understanding the purpose of the operation, and associating it with other operations (Blanton, 2008; NCTM, 2000). An algebraic solution involves writing an equation containing the unknown and solving this equation (Van Ameron, 2002). On the other hand, a mathematical problem can also be solved by focusing on the relations between quantities and quantities, and this approach is called quantitative reasoning (Smith \& Thompson, 2007).

Quantitative reasoning is an analysis of the situation with a structure that contains quantities, relations between quantities, and new quantities composed of these relations (Thompson, 1988). The most characteristic feature of quantitative reasoning is that numbers and numerical relations or variables are secondary in terms of importance. When analyzing the problem situations, first, nonnumerical inferences are made on quantities, and then how these quantities are related to the problem state is revealed. Thereafter, numbers and the relations between numbers, and the appropriate numerical operations for calculating the value of the quantity are taken into consideration (Thompson, 1993; Thompson, 2011). Analyzing quantitative information in this way helps students to decide which methods and strategies will be used to find the solution of the problem (Dwyer, Gallagher, Levin, \& Morley, 2003). In this context, it can be said that quantitative reasoning is a theory that sheds light on problem solving and makes sense of the solution process.

\section{Problem Solving and Quantitative Reasoning}

Problem solving is one of the most basic skills aimed to be developed from the pre-school period (CCSM, 2010; NCTM, 2000). Problem solving is a way of thinking and a process at the same time. There are various models in the literature that explain the steps of this process. The models of Polya (1945), Schoenfeld (1985), Verschaffel, De Corte, Lasure, Vaerenbergh, Bogaerts, and Ratinckx (1999) are some of these models. The model of Polya (1945), adopted within the scope of this study, consists of four stages; understanding the problem, preparing the plan for the solution, applying the plan and evaluating the solution. Various strategies, which are also called the paths of problem solution, such as systematic list-making, estimation and control, pattern searching, figure-diagram drawing, and drawing a table are also used in this process (Van de Walle, Karp \& Bay-Williams,2016). Quantitative reasoning is an approach that affects all stages of the problem-solving process and makes the process meaningful. One of the concepts that take an important place in the development of quantitative reasoning is problems based on real-world experiences. Smith and Thompson (2007) point out that the concept of "problem" should be reconsidered at the level of primary and secondary school mathematics for the development of quantitative reasoning skills of students. According to them, the concept of the problem consists of real-world situations in which students make reasoning about and conceptualize the relations between quantities.

If the focus is on the development of quantitative reasoning skills in solving real-world problems, then routine operations such as a numerical solution or variable assignment and equation solving cannot be applied. While the focus in an arithmetic solution is on numbers and the relations between numbers and the focus is on transforming relations into symbols in an algebraic solution, quantitative solution focuses on expressing quantitative relations and working with quantitative relations (Smith \& Thompson, 2007). The basic approach here is that it is important for a quantitative reasoner to understand the problem situation and to focus on relations between the quantities in the problem situation by determining the quantities in this context. Therefore, the concept of quantity is the concept that comes to the forefront in quantitative reasoning. According to Thompson (1988), quantity is the 
Tanışlı \& Dur - Çukurova Üniversitesi Eğitim Fakültesi Dergisi, 47(1), 2018, 60-108

representation or visualization of the measurable feature of an object in one's mind. In other words, quantity is a concept that is created in one's mind by considering the quality of that object so that one can understand the measurability feature of an object. Nevertheless, there is no need to measure quantities or to know the numerical values of their measurement results in order to be able to think about quantities.

One of the important concepts to be considered in the process of understanding the problem is quantitative operations. Quantitative operations are mental operations that ensure the formation of a new quantity from two existing quantities in one's mind. The new quantity found as a result of the quantitative operation also shows the relation between two quantities that are present in mind (Thompson, 1993; Smith \& Thompson, 2007). Quantitative operations are not the same as arithmetic operations but are related when the value of the quantity is known. In other words, arithmetic operations represent the value of a quantity (Smith \& Thompson, 2007). In the process of planning for the solution of the problem and implementing the solution, it is necessary to find the solution by interpreting the strategies chosen and the quantitative information, and to evaluate the result obtained with the problem situation in the ongoing process.

Studies on problem solving show that students from all grade levels have difficulties in various situations such as understanding the problem (Herscovics \& Kieran, 1980; Kamal \& Ramzi, 2000; Stacey \& MacGregor 1999), turning the verbal problem into the mathematical language (Lochhead, 1988), interpreting the problem (French, 2002), and using the appropriate strategy (Verschaffel, De Corte \& Lasure, 1999). Students may have difficulty in the problem-solving process when they solely focus on algebraic operations by assigning symbols to numerical values, arithmetic operations or unknown and cannot go beyond the operational dimension (Mayer, Lewis, \& Hegarthy, 1992; Smith \& Thompson, 2007; Thompson, 1993). Tambychik and Meerah (2010) stated that the reason for students to face difficulties in the problem-solving process is the lack of mathematical skills such as the concept of number, arithmetic skills, conceptual and operational knowledge skills, language skills, visual and spatial skills because students are obliged to apply and integrate many mathematical concepts and skills throughout the problem-solving process. Thompson (1988) also stated that the difficulties experienced in the problem-solving process may result from the failure to introduce the quantitative reasoning skill that considers the more basic, concrete relationship between quantities as of the early ages and is regarded as more informal than arithmetic or algebraic methods. According to Thompson, the acquisition of quantitative reasoning contributes both to the understanding of numerical expressions and operations in arithmetic, understanding of symbolic expressions and operations in algebra, and to the development of problem-solving skills. In this context, the studies he conducted supported the fact that the development of problem-solving skills can be ensured by the development of the quantitative reasoning skill (Smith \& Thompson, 2007).

The results of some studies show that the cognitive difficulties that students experience in complex problem-solving processes can be reduced, and the understanding and internalization of concepts can be ensured with the development of the quantitative reasoning skill (Ellis, 2007; Moore, 2010; Smith \& Thompson, 2007; Thompson, 1988; Thompson, 1993) because problem solving based on quantitative reasoning leads students to conceptual learning by moving them away from stereotyped solutions that are based on multi-dimensional inferences and learning by heart. For example, in a study conducted by Ellis (2007) who supported this idea, the quantitative reasoning skills of two groups of secondary school students, determined as the experimental and control groups, were investigated in the context of generalization. As a result of the study, it was determined that students in the group taught based on the relationship between quantities and quantities could meaningfully generalize the desired relationships in real life problems. In a study conducted by Moore and Carlson (2012) on university students, it was observed that students with advanced quantitative reasoning skills in solving real-world problems can solve problems more meaningfully. Similarly, another study conducted by Moore, Carlson and Oehrtman (2009) on university students has shown that quantitative reasoning is effective in problem solving. In the study conducted by Kabael and Akın (2016) and investigating the strategies and quantitative reasoning skills used by seventh-grade students when solving algebraic verbal problems, it 
Tanışlı \& Dur - Çukurova Üniversitesi Eğitim Fakültesi Dergisi, 47(1), 2018, 60-108

is emphasized that quantitative reasoning skills play an important role in the effective use of both arithmetic and algebraic strategies in the problem-solving process.

Curricula rich in quantitative reasoning at all levels from primary school are very important in the multidimensional development of problem-solving and quantitative reasoning skills. For example, when the mathematics curricula of countries such as China and Singapore are examined, it draws attention that the programs support quantitative reasoning and students of these countries have developed problem-solving skills (Cai, Ng \& Moyer, 2011). The mathematics curricula in Turkey do not directly emphasize quantitative reasoning, and it is emphasised that students are expected to express their thoughts and reasoning easily, and see the deficiencies or gaps in the mathematical reasoning of other people only in the problem-solving process (MNE, 2017). In Turkey, in many studies conducted on problem solving at all grade levels, it is expressed that students generally experience difficulties in the problem-solving process (e.g., Bayazıt, 2013; Çelik \& Güler, 2015; Şener \& Bulut, 2015). There are also various studies investigating the factors affecting the problem-solving process (e.g., Türnüklü \& Yeşildere, 2005). However, when these studies were examined, it was found out that the role of quantitative reasoning in the process of problem solving was not investigated, and only one study that investigates the quantitative reasoning skills of seventh-grade students in the process of solving verbal algebraic problems was encountered (Kabael \& Akın, 2016). Nevertheless, as Thompson (1988) argues, quantitative reasoning, which has concrete, intuitive and unique models, can be used as an alternative approach inproblem solving teaching. Based on these ideas, the quantitative reasoning skill levels of students in Turkey and what kind of a change can occur in the problem-solving skills of students in case training is provided on the development of this skill necessitated this study. The general aim of the study is to determine the role of the quantitative reasoning development of two students studying in the sixth grade of secondary school in the ability to solve real-world problems. The answers to the following two questions were sought in line with this aim.

1. How do two students studying in the sixth grade of secondary school solve and interpret real-world problems?

2. How do two students studying in the sixth grade of secondary school solve and interpret real-world problems after the training?

The study is limited to the clinical interviews before and after the training. It is believed that the study is important in that it reveals how the skills of the students of determining quantities, determining the relations between quantities, and interpreting and making inferences from the quantitative information were at the beginning and at the end in the problem-solving process. Furthermore, the study is important in that the problems used in the study and the ways which the students follow in the problem-solving process set an example to teachers, pre-service teachers, and mathematics educators.

\section{Method}

\section{Research Design}

The teaching experiment design was adopted in this study (Cobb \& Steffe, 1983). The reason for choosing this design is that researchers can see how students' problem-solving skills have changed with the development of quantitative reasoning before and after the training (Steffe, 1991). In this context, one of the researchers was present in the environment as a teacher, and he conducted research while the teaching activities were maintained at school or in the classroom environment.

Teaching was performed on sixth-grade students for five weeks and in 10 course hours. In this process, training was provided on problem-solving (Van De Walle et al., 2016), and the four-stage problem-solvingmodel of Polya (1945) was used in this framework. In the teaching process, activities including real-world problems that require quantitative reasoning with different contents and levels (from simple to complex) similar to those used in the studies of Smith and Thompson (2007) were created. In this process, the researcher first had the participants solve the problems with individual or small group studies, and then asked questions such as "What does your finding mean?", "What are you 
trying to find?" by creating environments that would enable them to share their solutions and thoughts. Moreover, he tended to listen to his students well. It is important for students to use visual representations while explaining quantities in the problem-solving process in terms of reasoning in the classroom interaction. At this point, the researcher asked the students to express the definitions they wanted to explain by using representations such as diagrams, figures, tables (Smith \& Thompson, 2007). Besides, he encouraged his students to use different strategies in the problem-solving process.

\section{Participants}

The participants of the study are two focus students selected among students attending the sixth grade at a secondary school located in the centre of a province in Turkey. In the selection of students, criteria sampling among purposeful sampling methods was used (Yıldırım \& Şimşek, 2013) and students' mathematical achievement levels were taken as a criterion. In this context, a male student with a high level of achievement and a female student with a middle level of achievement were selected on the basis of volunteerism within the scope of the study, considering the mathematics lesson grade scores, the results from the test examinations made at school, and the teacher's opinion. Students with the low achievement level were not preferred as participants in this study, since gaining quantitative reasoning skills actually takes a long time and requires a certain level of readiness in participants.

\section{Data Collection}

The main data of the study were collected by the clinical interview technique applied before and after teaching (Clement, 2000, p. 547). In addition to this, student worksheets, student diaries, the researcher's diary were also used as support data. real-world problems were created in quantitative difference, complex additive situations, combination of differences and quantitative ratio, which can reveal the quantitative reasoning skills of the students for pre- and post-clinical interview questions. In this process, the problems in the studies of Smith and Thompson (2007) were used. In problem situations containing a quantitative difference, the result of comparing two quantities in an additive manner is present, while in problem situations containing a quantitative ratio, a new quantity is obtained as a result of the multiplicative comparison of two quantities. Problem situations involving complex additive situations involve one or more quantitative differences whereas problem situations involving relational complex situations involve at least six quantities and three quantitative operations (Smith \& Thompson, 2007).

The clinical interview questions prepared were then presented to two expert mathematics educators. Then, in order to test the comprehensibility of the questions and develop the questions at the end, a pilot study was carried out on a voluntary student with a medium level of achievement attending the sixth grade, and necessary corrections were made on the questions. The clinical interviews were conducted by a researcher and the interview with a student was completed in four days, in a way that it did not exceed an average of 30-40 minutes per day.

\section{Data Analysis}

The thematic analysis method was used in the analysis of the research data. In the thematic analysis, the existing themes used in various models can be utilized as well as themes and patterns can be found for the data (Liamputtong, 2009). In this study, the codes and themes were associated with the problem-solving stages and quantitative reasoning indicators, and the process presented in Figure 1 was created. 
Tanışı \& Dur - Çukurova Üniversitesi Eğitim Fakültesi Dergisi, 47(1), 2018, 60-108

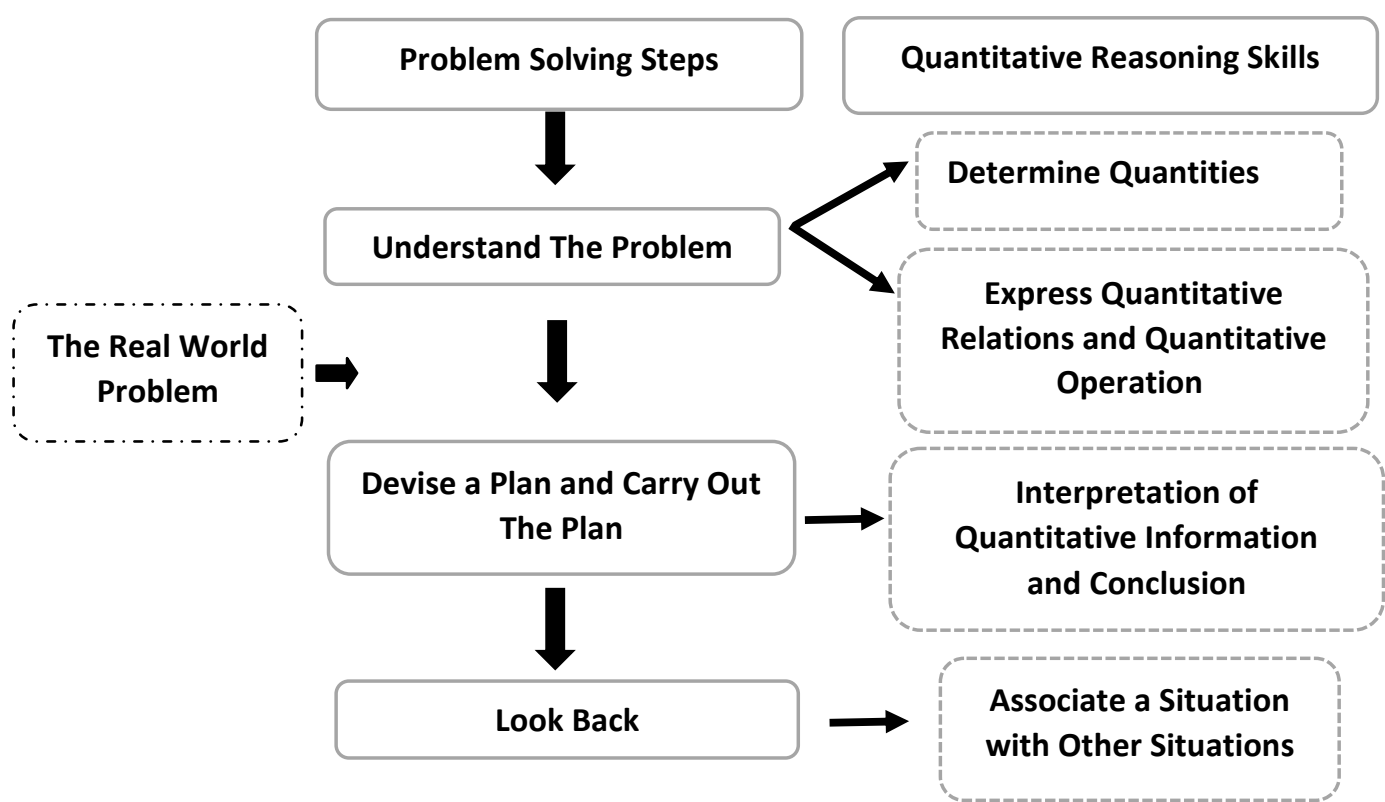

Figure 1. Relationship between problem solving process and quantitative reasoning skills

The analysis process was performed in two steps. First, the data from the interviews, worksheets, and the students' and researcher's diaries were itemized. Then, the data were read repeatedly, and it was attempted to understand the thoughts expressed by the participants. In the second step, coding was started. In the coding process, each type of problem was evaluated separately, and the solution processes of the students were examined. If the student could express the problem "in his/her own words" and "if he/she could identify what was given and requested in the problem", these expressions were addressed as codes and collected under the sub-theme of "understanding the problem". Then, the "strategies" used by the student made up the other code, and this code was defined with the sub-theme of "devise a plan and carry out the plan". Finally, if the student "could control and interpret the result of the solution" this was addressed under the sub-theme of "look back". All sub-themes defined were expressed with the theme of "problem-solving process". On the other hand, in the stage of understanding the problem, if the student could "determine quantities", "express quantitative relations and quantitative operations" and express these relations with "visual representation" in a problem situation, and if the student "could interpret and make an inference from the quantitative information" in the stage of planning for the solution and applying the solution, and "associate a situation in the problem with a situation in another problem" in the stage of assessment, all these expressions were addressed as codes and defined under the theme of "quantitative reasoning skills".

The coding and theming process was carried out independently by the researcher and expert in mathematics education, the reliability was calculated, and $80 \%$ reliability was ensured (Miles \& Huberman, 1994, p. 64). Codes and themes were presented in figures in the findings, and the students were represented using the initials of their nicknames (Atakan and Emel), and their achievement levels were represented by using the indices " $\mathrm{H}$ " for high and " $\mathrm{M}$ " for medium. Furthermore, the numerical value of 1 was used for simple, 2 for medium, and 3 for high, respectively, in order to represent the level of complexity of the problems, from simple to complex. 


\section{Results}

The Problem-Solving Processes and Quantitative Reasoning Skills of Two Students in Solving Quantitative Difference, Complex Additive Situations, Combination of Differences and Quantitative Ratio Problems Before Training

The solution performance, solution steps and quantitative reasoning skills of the students in the process of solving real-world problems presented in Figure 2 containing a quantitative difference are presented in Figure 3.

\section{The real-world problem containing a quantitative difference}

The information on the goals scored by Eskişehir, Trabzonspor and Galatasaray football teams against one another in the matches is as follows:

1) Eskişehirspor scored 5 goals against Galatasaray, and 4 goals against Trabzonspor; Galatasaray scored 2 goals against Eskişehirspor, and 3 goals against Trabzonspor; and Trabzonspor scored 1 goal against Eskişehirspor, and 6 goals against Galatasaray. According to the information given, compare Trabzonspor's average goal status at the beginning and average goal status at the end.

2) Eskişehirspor scores 4 goals against Galatasaray, and 7 goals against Trabzonspor; Galatasaray scores 1 goal against Eskişehirspor, and 2 goals against Trabzonspor; and Trabzonspor scores 3 goals against Eskişehirspor and it has 5 more average goals at the end of the matches when compared to the beginning. Accordingly, find how many goals does Trabzonspor score against Galatasaray.

3) Eskişehirspor scored --- goals against Galatasaray; --- goals againstTrabzonspor, Galatasaray scored --- goals againstEskişehirspor; --- goals against Trabzonspor, and Trabzonspor scored -- goals against Eskişehirspor; --- goals against Galatasaray. Arrange the gaps in such a way that by the end of the matches, Trabzonspor's average goals will be 2 less than its average goals at the beginning.

\section{Figure 2. The real-world problem containing a quantitative difference}

As can be seen from Figure 3, when the students' solution performances were examined, it was observed that only the simple complicated level problem could be solved by Atakan. When starting to solve the real-world problems containing a quantitative difference, Atakan and Emel expressed the problems with their own words and determined what was given and requested. In this process, both students noticed the quantities as "scored goals" and "goals conceded" in the problem. However, both fell short in explaining the quantitative relations of "the additive difference between conceded and scored goals" or "how goals averages change", which was reflected in their problem solutions. For example, Emel used the strategy of listing (listing the possibilities of a situation) in the solution of the three problems in the stages of planning and implementation of the plan but failed to solve the problems. Since Emel could not discover the quantitative relation, in other words, she could not understand the quantitative difference completely, she performed meaningless arithmetic operations between the number of scored and conceded goals as can be observed below. 
Tanışı \& Dur - Çukurova Üniversitesi Eğitim Fakültesi Dergisi, 47(1), 2018, 60-108

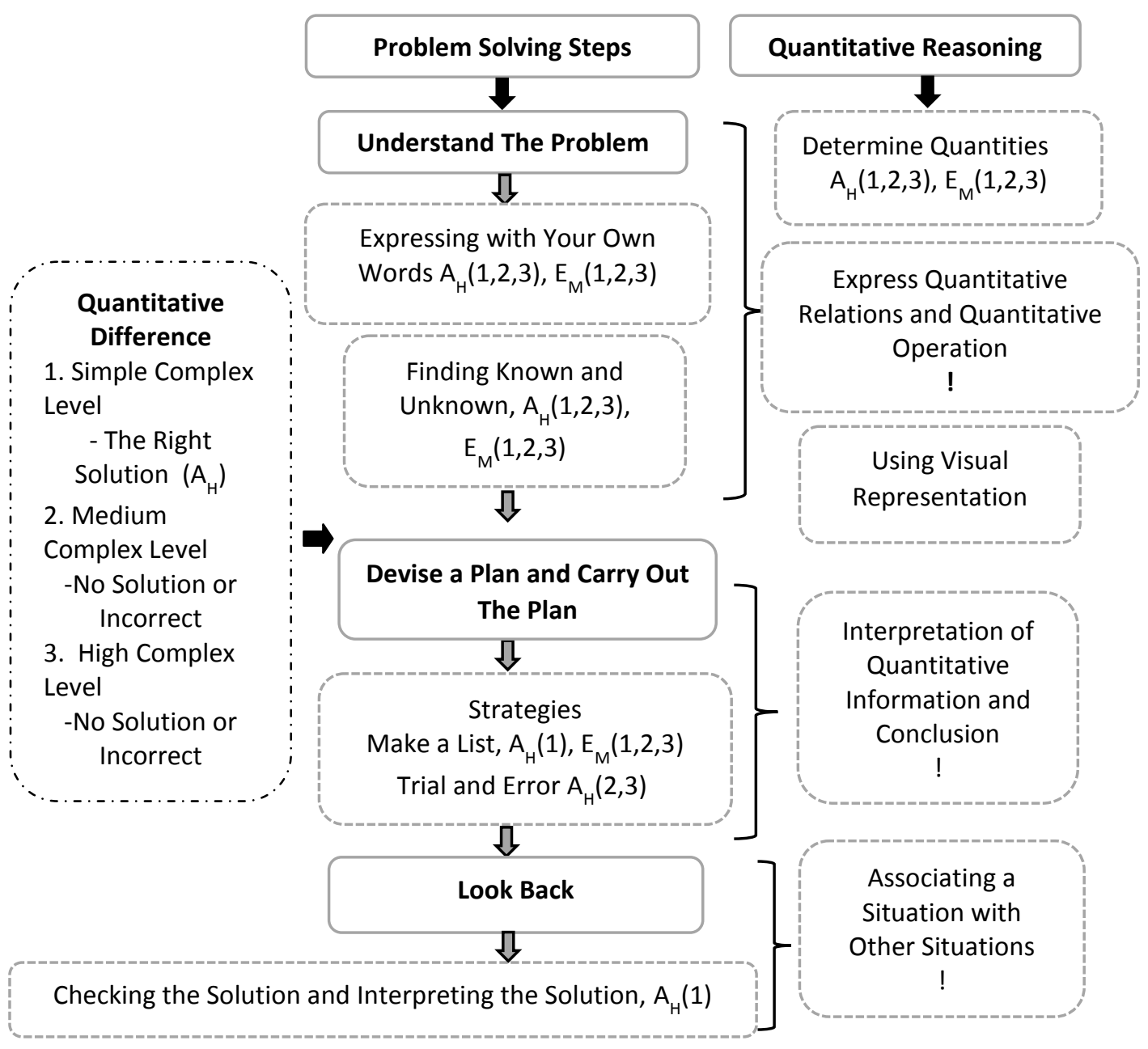

Figure 3. The problem-solving processes and quantitative reasoning skills of the students in the process of solving the problems containing a quantitative difference

At the same time, Atakan used the strategy of listing in the solution of the simple complex level problem in the stage of planning and implementation of the plan; he directly focused on the numbers and found the correct result with the arithmetic operation of "he conceded 4 goals, conceded 3 goals and scored 7 goals $4+3=7-7=0$ ". In the assessment stage, he interpreted the solution by checking its accuracy. Nevertheless, although Atakan succeeded in the first problem and he could interpret the quantities in the problem, he had difficulty in finding the "additive difference between the goals conceded and scored by Trabzonspor", in other words, discovering the quantitative relation, and interpreting the state of "an average of 5 more goals when compared to the first situation" in the second problem, which is related to the first question, since he failed to make quantitative reasoning. He experienced a similar difficulty in the third problem, and he could not explain the state that the "goal average is 2 less when compared to the first situation," and he used the trial and error strategy (making random meaningless arithmetic operations) to solve these problems.

The solution performances, solution steps and quantitative reasoning skills of the students in the process of solving the problems containing complex additive situations given in Figure 4 are presented in Figure 5. 
There are two classes at a university ( $\mathrm{S} I$ and $\mathrm{S} 2$ ) and (Mı and $\mathrm{M} 2)$.

1) The sum of the numbers of students of $M_{1}$ and $M_{2}$ is 82 . The number of the students of $S_{1}$ is 8 more than the student number of $M 2$, and the number of the students of $S 2$ is 3 less than the student number of $M_{1}$. As $M_{2}$ has a total of 36 students, what is the total number of the students of $S_{1}$ and $S 2$ ?

2) The total number of the students of $M_{1}$ and $M_{2}$ is 82 , and the total number of the students of $\mathrm{SI}$ and $\mathrm{S} 2$ is 87 . The number of the students of $\mathrm{S} I$ is 8 more than the number of the students of $M_{2}$, and the number of the students of S2 is 3 less than the number of the students of $M_{1} . M_{1}$ has a total of ... students. Which number or numbers can be written to the gaps in order to fulfil the situations given in the problem?

3) The total number of the students of $M_{1}$ and $M_{2}$ is 82 , and the total number of the students of $S_{1}$ and $S 2$ is 84 . The number of the students of $S_{1}$ is 8 more than the student number ofM2, the number of the students of S2 is 3 less than the number of the students ofMı. There is a total number of --- students in Mı. Which number or numbers can be written to the gaps in order to fulfil the situations given in the problem?

Figure 4. The real-world problem containing a complex additive situation

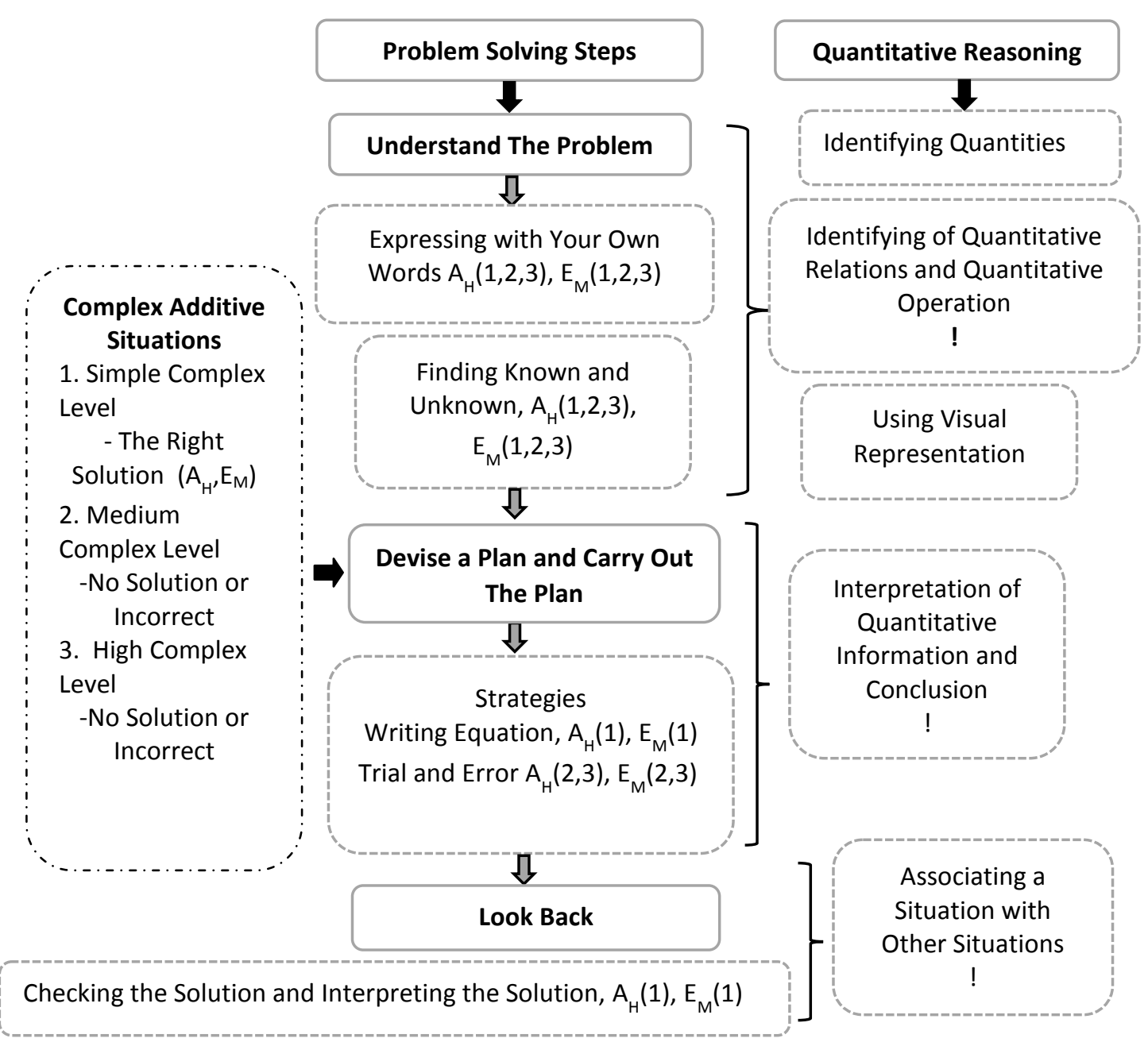

Figure 5. Solution processes and quantitative reasoning skills of the students in the process of solving a problem containing complex additive situations 
Tanışlı \& Dur - Çukurova Üniversitesi Eğitim Fakültesi Dergisi, 47(1), 2018, 60-108

As can be seen from Figure 5, Atakan and Emel were only able to solve the problem given at the simple complex level and failed to solve the problems at the medium and high level of complexity. While beginning to solve the problems, Atakan and Emel expressed the problems with their own words, and they could determine what was given and required. Nevertheless, in this process, both students directly focused on numbers and the unknown without focusing on the quantities in all three problems, and they used the equation writing strategy (writing a mathematical equation in which the unknown is represented with a letter) in the first problem, and the trial-error strategy in the solution of the other two problems, in the stage of planning for the solution and implementing the plan, and they performed the solutions in an algebraic way. In the assessment stage, they checked the accuracy of the result. In the case of two other problem situations with the increasing level of difficulty that require quantitative reasoning, the students used the trial and error strategy and could not achieve the correct answer since they failed to interpret the quantities as the "total number of students in classes" and "the difference between the total numbers" or "the difference between the two grades in two different departments", in other words, the relations between quantities.

The solution performances, solution steps and quantitative reasoning skills of the students in the process of solving the problems containing the combination of the differences given in Figure 6 are presented in Figure 7.

\section{The real-world problem containing the combination of the differences}

Ahmet and Batuhan make a bet on which one will have more nets than his sister. It is observed that Ahmet wins the bet with 12 nets after the exam. Fill in the gaps with the suitable numbers that will fulfil the problem situation in this exam.

1. Ahmet:92 nets, his sister Emine:76 nets; Batuhan: 98 nets: his sister Şule: --- nets

2. Ahmet:92 nets, his sister Emine:76 nets; Batuhan: --- nets; his sister Şule: --- nets

3. Ahmet: --- nets, his sister Emine: --- nets; Batuhan: --- nets; his sister Şule: --- nets

Figure 6. The real-world problem containing the combination of the differences

As can be seen from Figure 7, Emel could solve only the problem given at the simple complex level. When starting to solve the problems, both students expressed the problem in their own words, but Atakan could not determine what was given and what was requested, so he could not understand the problem. In problem situations, the students are first expected to become aware of seven quantities (i.e. the scores of Ahmet, his sister Emine, Batuhan, his sister Şule, and the difference between the other quantities obtained from the two quantities and the difference between the scores of Ahmet and Emine, and the difference between the scores of Batuhan and Şule, and finally, Ahmet's claim, which is the new quantity that arises as the difference of the difference). In this process, it is important that students first compare the two differences in the context of quantitative reasoning, in other words, compare the "mathematics score between the siblings" and the "score between the two friends" and discover the quantitative relationship of "the difference of the differences". Emel failed in the problems apart from the first problem, while Atakan failed in the solution of all the problems since he could not realize this situation.

In the planning and implementation stage, Emel used the strategy of reasoning in all three problems (obtaining $q$ based on the $p$ state that is correct) but achieved the correct result only in the first problem. She primarily focused on numbers and operations in the problem, and she found the solution as "Ahmet has 92 nets and Emine has 76 nets. 92 minus 76 is 16... If the net difference between Batuhan and Şule is 4, Ahmet wins with 12 nets" by making arithmetic reasoning. In the assessment stage, she checked the accuracy of the result. Emel is actually aware of the quantities in this problem. Nevertheless, she had difficulty in other problems with an increasing level of difficulty since she did not fully conceptualize the quantitative difference and the different relations of the difference. Since Atakan could not discover the quantities and the relation between these quantities, he used the strategy of trial and error in all problem situations and could not reach the solution. For example, in the first problem, 
he performed meaningless arithmetic operations such as "If Emine scored 76 and she surpassed Şule with 12 nets, 76-12=64 and Şule scores 64".

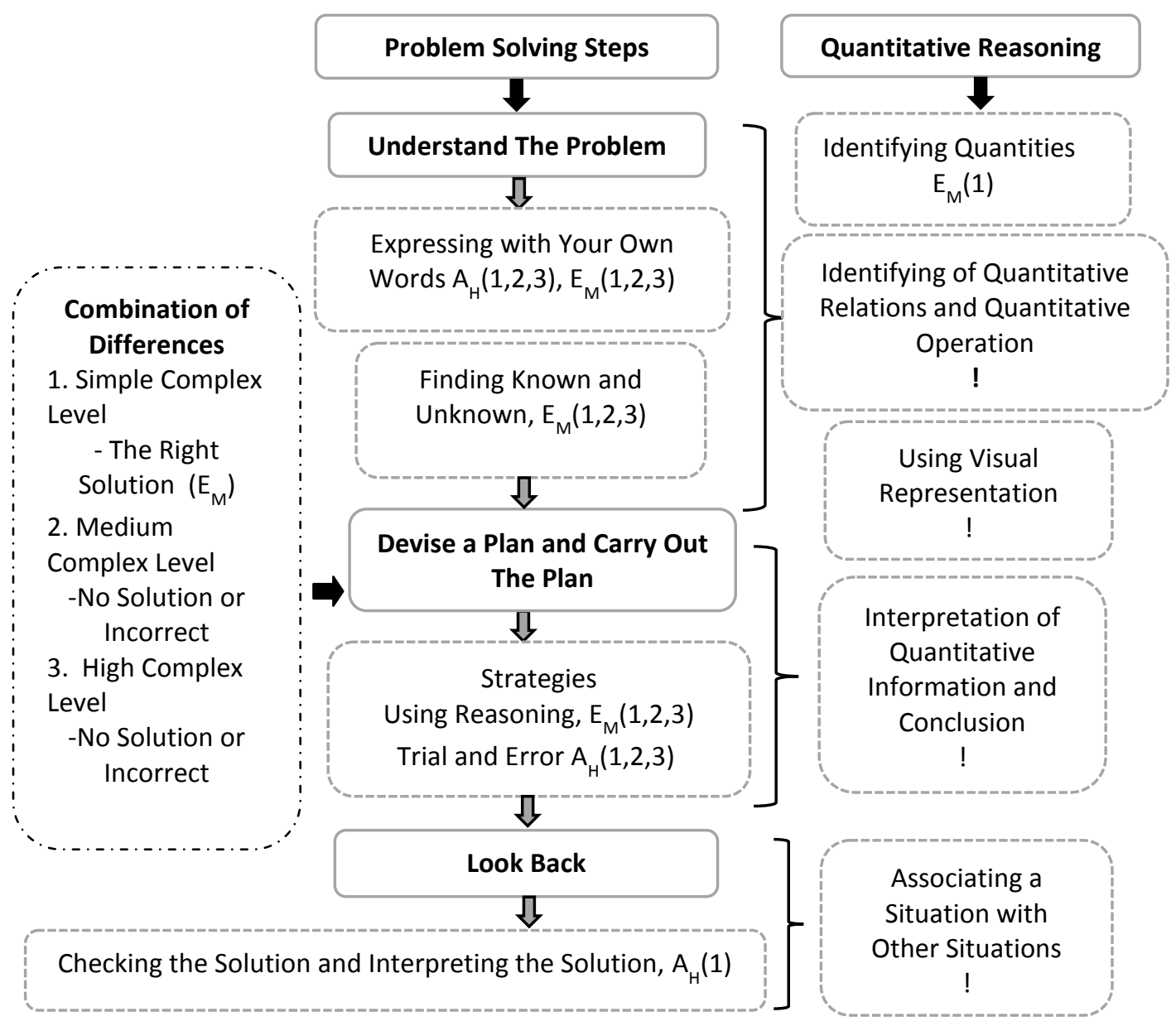

Figure 7. Solution processes and quantitative reasoning skills of the students in the process of solving a problem containing the combination of the differences

The solution performances, solution steps and quantitative reasoning skills of the students in the process of solving the problems containing a quantitative ratio in Figure 8 are presented in Figure 9.

\section{The real-world problem containing a quantitative ratio}

1) Ayhan will be 45 years old at a later time in the future. Then, Ayhan will be 3 times older than the age of his daughter Feyza. As Feyza is 11 years old now, how old is Ayhan?

2) Tap A fills a pool in 60 minutes, while tap $B$ fills another pool with the same capacity (volume) in 80 minutes. How many minutes later will the amount of water in both pools be the same, as tap B is opened 15 minutes before tap A?

Figure 8. The real-worldproblem containing a quantitative ratio 


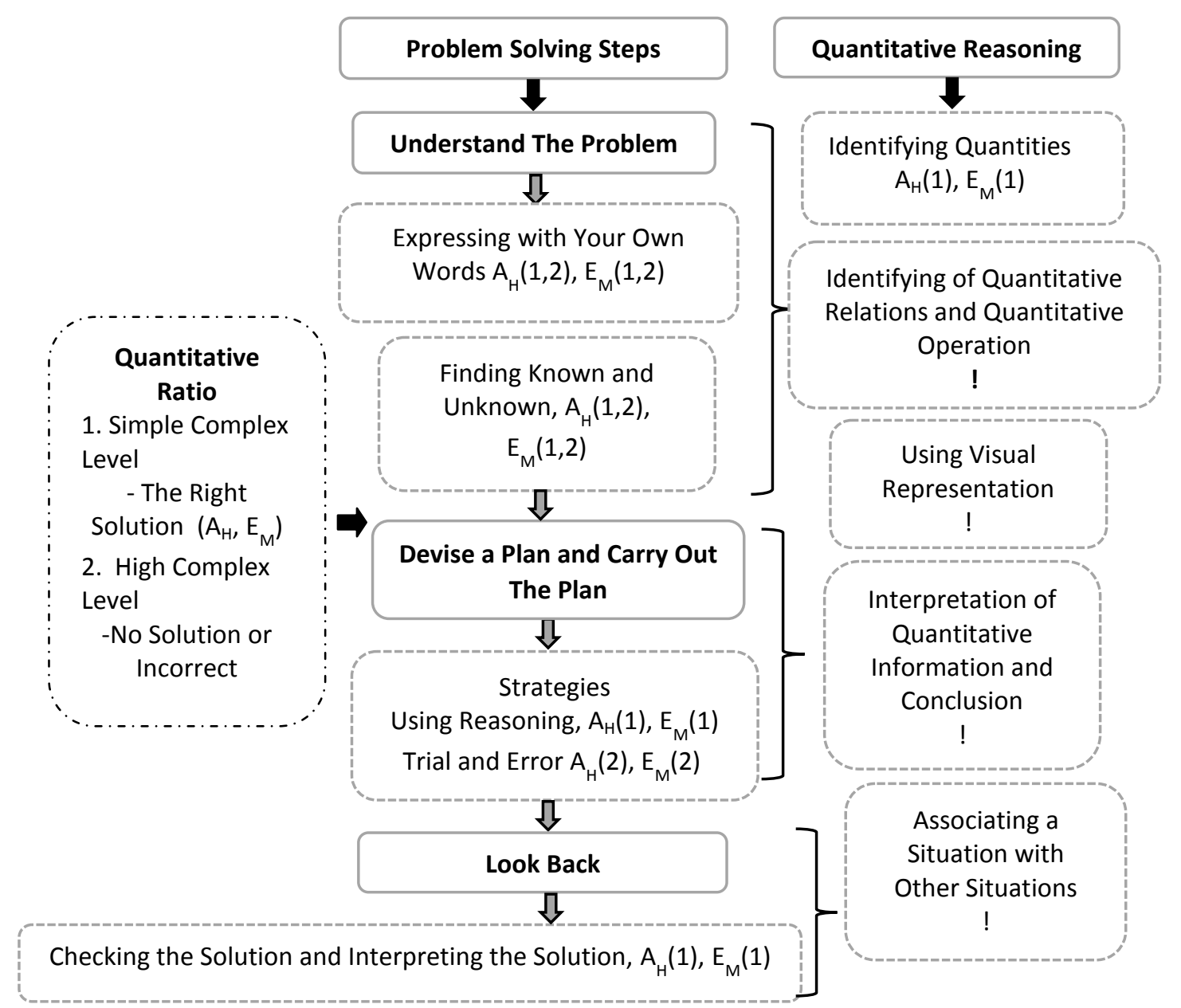

Figure 9.Students' solution processes and quantitative reasoning skills in the process of solving a problem containing a quantitative ratio

As can be seen from Figure 9, both students could only solve the problem at the simple complex level and failed to solve the problem at the highly complex level. When starting the problem at the simple complex level, Atakan and Emel expressed the problem with their own words and determined what was given and requested. The students became aware of four quantities (the father's and daughter's current ages, the father's and daughter's future ages) in this problem situation. Nevertheless, both students directly focused on numbers and started to solve the problem without fully expressing the temporal relationship, quantitative difference, and quantitative ratio relations. In this context, Atakan and Emel used the strategy of reasoning in the planning and implementation stage and in this process, they performed arithmetic operations in three steps. In the solution, they first determined the future age of the girl, then they found the difference between the present and the future ages, and finally, they subtracted this difference from the father's age. In other words, they reached the correct solution by selecting three numbers $(45,3,11)$ and the correct arithmetic operation (division, subtraction) to be used in the problem. In the final assessment stage, they checked the accuracy of the solution. Emine's solution was presented as an example. Atakan also suggested a second solution for this problem situation with the following reasoning " --- 11 plus what makes it a multiple of 45".

When starting the second problem, both students expressed the problem with their own words and determined what was given and requested. However, the students were unable to perform reasoning 
Tanışlı \& Dur - Çukurova Üniversitesi Eğitim Fakültesi Dergisi, 47(1), 2018, 60-108

upon the quantities in the problem situation (the durations during which taps $A$ and $B$ fill the pool, the times when tap B and A start to fill the pool, and the time when the amount of water in both pools is equal) and quantitative relationships between them (filling ratios and durations of the two taps). In other words, they failed to interpret the information that the difference between the amounts of water in the pool would be closed at a rate that is a difference of filling ratios and durations. Therefore, they used the strategy of trial and error in the planning and implementation stage and performed meaningless arithmetic operations.

For example, Atakan failed to find the answer to the problem because he initially misinterpreted the ratios and durations of the taps to fill the pools.

When all problem situations were taken into consideration, it was observed that students focused more on numbers and numerical relations rather than quantities and the relations between quantities, and they generally used the trial and error strategy in problems in solving of which they generally had difficulty. Furthermore, it was observed that in general, they could solve the problem situations given at the simple complex level, while they had difficulty in solving the problems as the level of complexity increased. When students' diaries were examined, it was observed that the students generally claimed that they had difficulty in solving the problems since they had not encountered such problem situations before.

Problem Solving Processes and Quantitative Reasoning Skills of the Two Students in Solving the Problems of the Quantitative Difference, Complex Additive Situations, the Combination of the Differences and Quantitative Ratio Types after the Training

The solution performances, solution steps and quantitative reasoning skills of the students in the process of solving the problems presented in Figure 10 and containing a quantitative difference are presented in Figure 11.

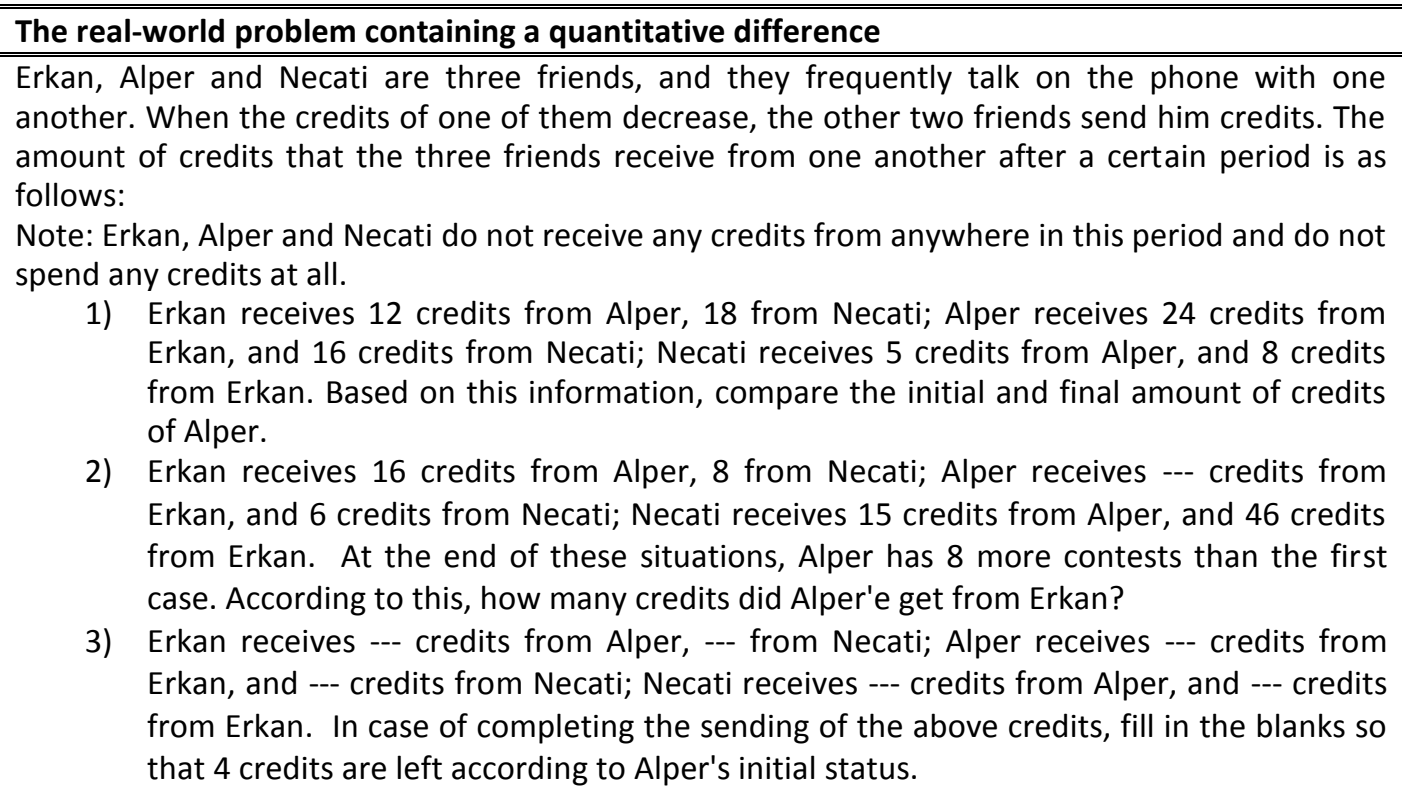

Figure 10. The real-world problem containing a quantitative difference

As seen in Figure 11, Atakan and Emel could solve the three problems while starting to solve the problems containing a quantitative difference. Atakan and Emel expressed the problems with their own words and determined what was given and requested. In this process, they became aware of quantities such as the "credit sent" and "credit received" in the problem, and they represented the values of these quantities with the signs plus for the incoming credits and minus for the credits sent. They also determined the quantitative relationship with regard to "the additive difference between sent and 
received credits" and "how the amount of credit at the beginning and at the end changed." In this stage, Atakan showed the quantitative relations he determined by drawing a diagram.

The conceptualization of quantities and the relationship between quantities was also reflected in the solution processes of both students, and they used the strategies of list making, using the solution of similar problems (solving by associating it with a simpler similar problem), performing reasoning, and estimation and checking (making an estimation in relation to the answer to the problem and examining whether this estimation is the response) in the planning and implementation stage. The list-making strategy was used correctly by Atakan and Emel in three problems, and the correct solution was found by the quantitative method. In the assessment stage, the accuracy of the result was checked and interpreted. Emel's solution is presented as an example below.

Emel found the solution to this problem by interpreting the quantitative information discovered as "First, I found the loss. $16+15=31$ is the loss, and 6 is the profit. $31-6=25$ is the loss. It will first make up for 25 , and then it should be added $25+8=33$ to surpass by 8 ." As can be seen, Emel used the solution of the profit-loss problems in the solution of the problem in a similar way with Atakan. At the same time, Atakan solved the problem as shown in Figure 12, upon the diagram he drew at the beginning of the problem.

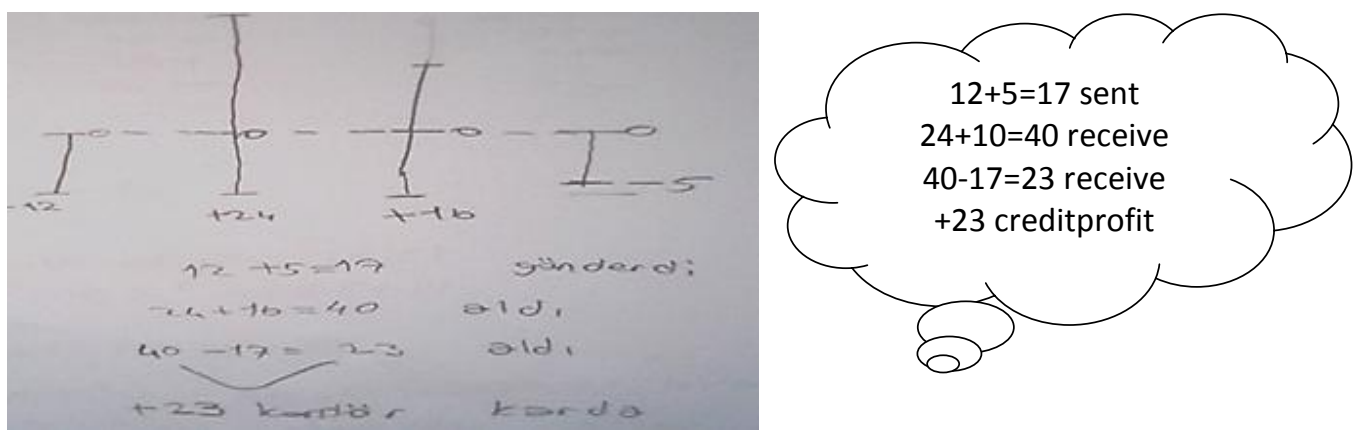

Figure 12. Atakan's solution

Atakan interpreted the quantitative information in the following way: "Necati and Erkan do not have any importance. So, I just drew Alper. In my first solution, I may have not written the other people. The important person is Alper. Only the states that Necati and Erkan sent credit to Alper and received credit from Alper are important. The credits that Necati and Alper sent to and received from one another are not important", and reached a solution accordingly. In the assessment stage, the students reached the result by associating the problem situations respectively with each other since they determined the quantities, quantitative relations, and operations at the beginning of the problem.

As shown in Figure 11, Atakan and Emel used the strategies of reasoning and estimating and checking in the solution of the second and third problems. For example, in the solution of the third problem Atakan made an explanation as follows:

$A_{h}$ : The amount of credits Erkan and Necati sent to each other does not concern us. We can write the numbers we want in the credits they sent to each other. After I write the first 3 states of Alper, I will judge the final state according to the order. I found that it is correct when I crosschecked it.

Res: Then, which numbers can be written in the gaps here?

$A_{h}$ : Many numbers can be written in the gaps. Only if Alper is minus 4 when compared to the initial state. For example; Alper gave 100 and received 96, then he is minus 4; or he gave 2000, and received 1996, and he is minus 4 again.

Res: What kind of a relationship is there between the numbers that can be written in the gaps?

$\mathbf{A}_{\mathrm{h}}$ : Any number, as long as Alper has minus 4 credits. 


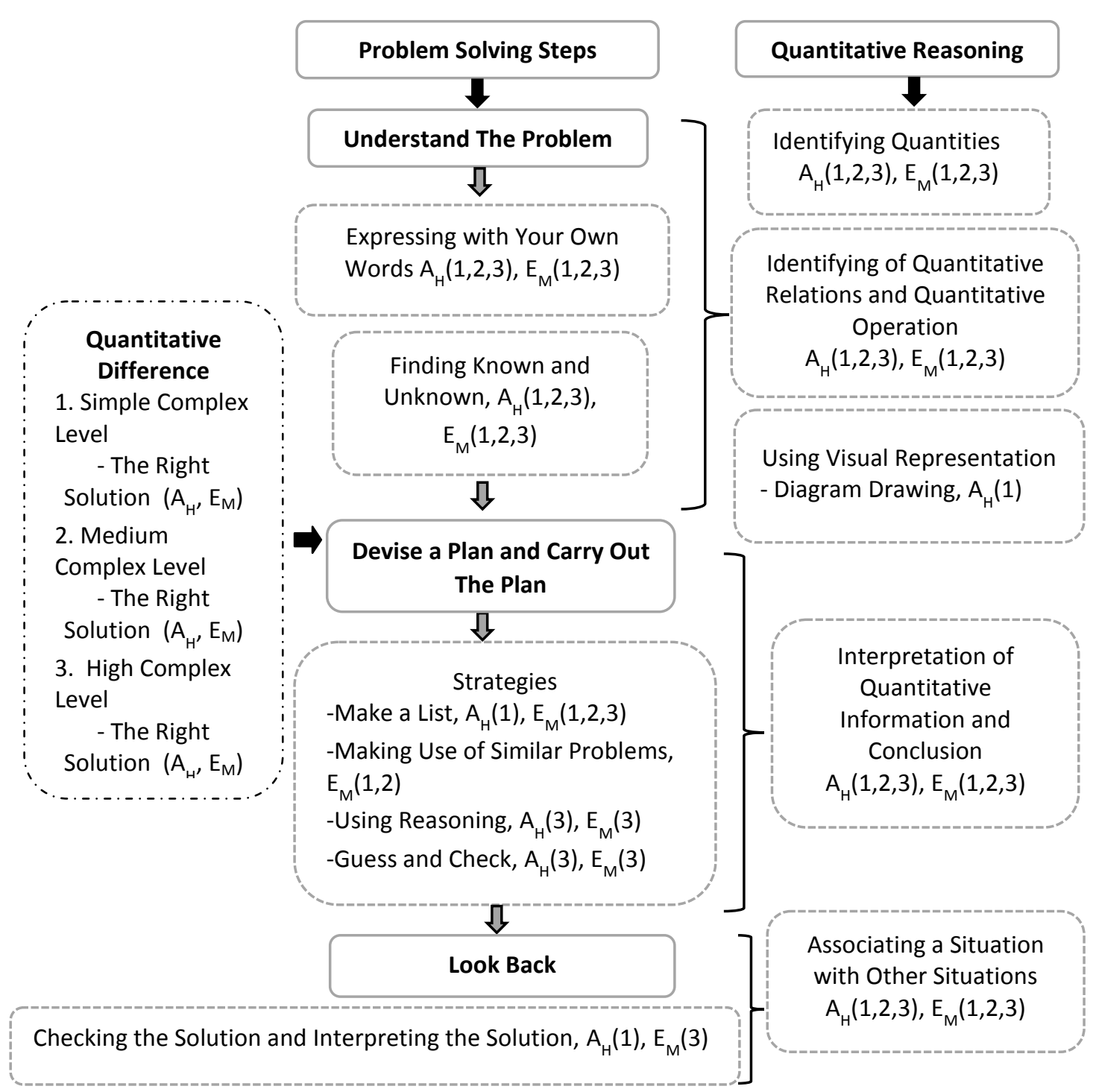

Figure 11. Students' solution processes and quantitative reasoning skills in the process of solving problems containing a quantitative difference

As can be seen from the dialogue, it can be said that the student focused on the state of Alper and explored the quantitative relation through quantitative reasoning (the relation between Alper's first state and the final state) in the problem. At the same time, it seems that the quantitative information he discovered was interpreted by the strategy of estimation and control and that a solution was reached (that any number can be written in the gaps as long as it is minus 4). In the assessment stage, both students tested the accuracy of their results.

The solution performances, solution steps and quantitative reasoning skills of the students in the process of solving the problems that contain a complex additive situation given in Figure 13 are presented in Figure 14. 
The real-world problem containing a complex additive situation

In a knowledge contest between two groups, Emine and Gülşen are in the first group and their opponents Hakan and Ahmet are in the second group. The following information is given on the knowledge contest held over 100 questions.

1) The total number of the questions that were answered correctly by Hakan and Ahmet is 94. The number of the correct answers of Emine is 2 less than that of Ahmet, and the number of the correct answer of Gülsen is 6 more than that of Hakan. As the number of the questions that Ahmet answered correctly is 42, what is the total number of questions that Emine and Gülşen answered correctly? Which group won the contest?

2) The total number of the questions that were answered correctly by Hakan and Ahmet is 94. The total number of the questions that were answered correctly by Emine and Gülşen is 98. The correct answers of Emine is 2 less than that of Ahmet, and the number of the correct answers of Gülsen is 6 more than that of Hakan. The number of correctly answered questions by Gülsen is .... Which number of numbers can be written to the gap in order to fulfil the situations given in the problem?

3) The total number of the questions that were answered correctly by Hakan and Ahmet is 94. The total number of the questions that were answered correctly by Emine and Gülsen is 96. The number of the correct answers of Emine is 2 less than that of Ahmet, and the number of the correct answer of Gülsen is 6 more than that of Hakan. The number of the questions that were answered correctly by Gülsen is ---Which number of numbers can be written in the gap in order to fulfil the situations given in the problem?

Figure 13. The real-world problem containing a complex additive situation

As shown in Figure 14, Atakan and Emel could solve three problems. While starting to solve the problems, Atakan and Emel expressed the problems with their own words and determined what was given and required. In this process, the students are expected to become aware of the quantities as "the total number of correct answers of Ahmet and Hakan, and Emine and Gülşen" and "the difference between the correct answers of Emine and Ahmet, and Gülşen and Hakan". It is also important that they determine the quantitative relation between these quantities, i.e., "the difference between the correct answers of Ahmet and Hakan, and Emine and Gülşen." In this context, Atakan showed this situation in all the questions, while Emel found the solution by using the strategy of writing an equation by primarily focusing on numbers and the unknown, just as in the preliminary clinical interview in the simple complex level problem. Nevertheless, she tended towards quantitative operations in the second and third problems with the increasing level of difficulty.

In the stage of understanding the problem, Atakan showed the quantities and the relations between them by drawing diagrams in all problems, while Emel used diagrams in the second and third problems. In the stage of planning and implementation of the plan, the students used the reasoning and estimation and checking strategies, and Emel also used the strategy of writing an equation in the first problem as mentioned above. 


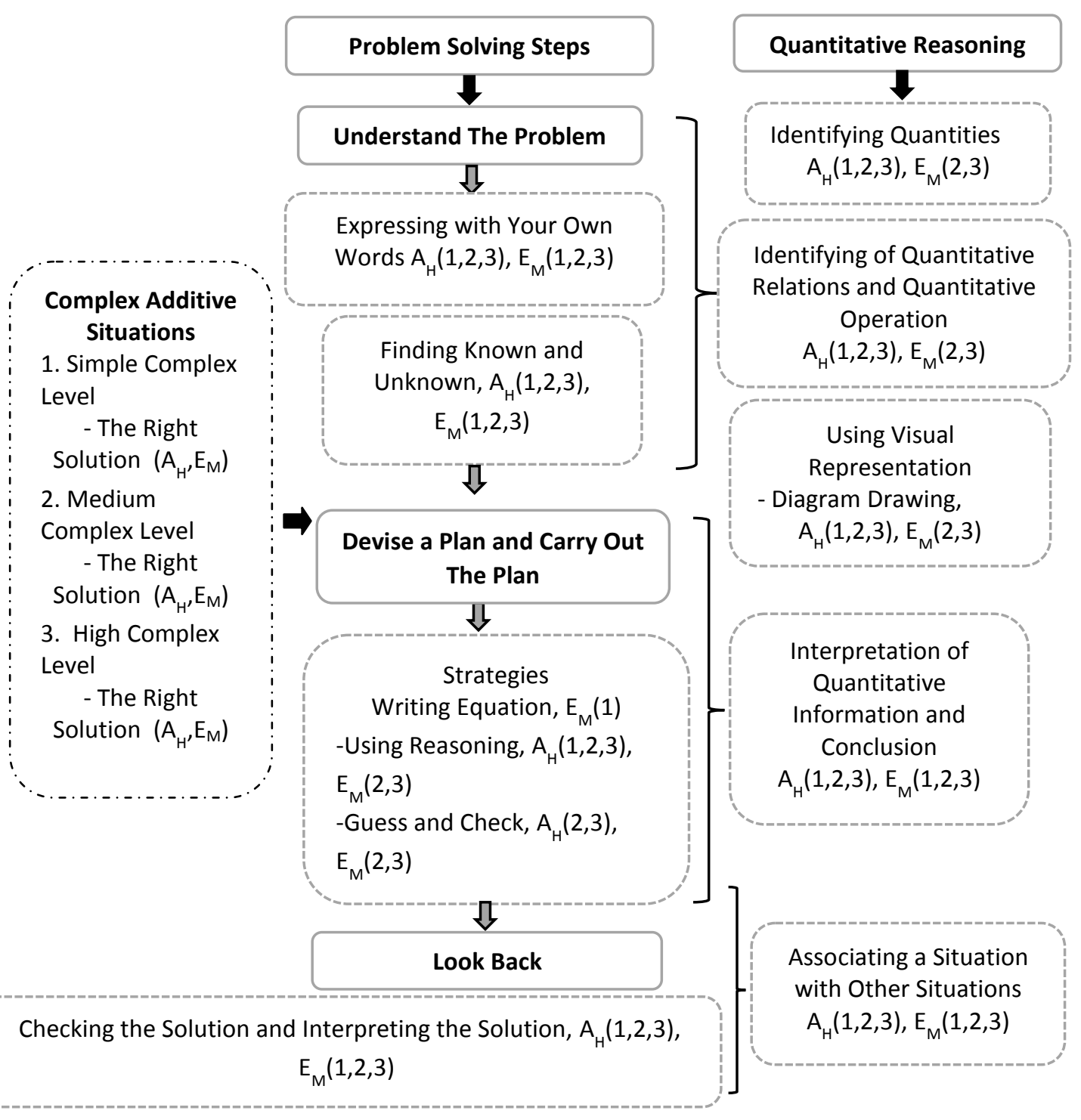

Figure 14. Solution processes and quantitative reasoning skills of the students in the process of solving a problem that contains complex additive situations

The solution and explanations of the second problem upon the diagram drawn by Emel in the stage of understanding the problem are presented in Figure 15.

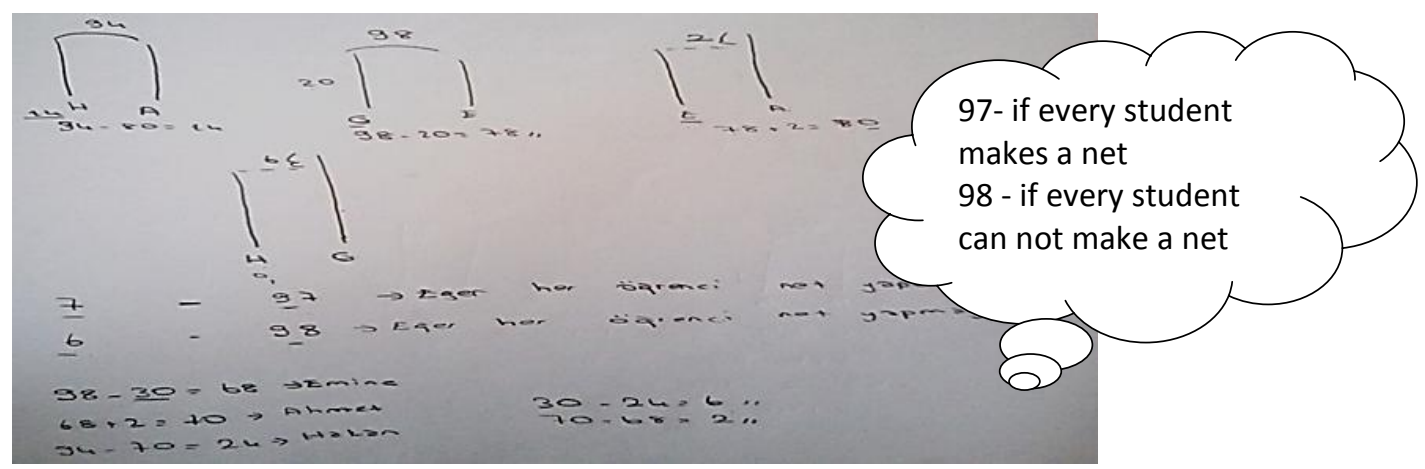

Figure 15. Emel's solution 
Tanışlı \& Dur - Çukurova Üniversitesi Eğitim Fakültesi Dergisi, 47(1), 2018, 60-108

$\mathbf{E}_{\mathrm{M}}$ : If each student is to make at least 1 net, Gülşen will make at least 7, for Hakan to have 1. At the top; it is 97 for Emine to have 1. If there is no such thing as each student should have 1 net, then the number of correct answers of Gülşen should be between 6 and 98 because if Gülşen does not have 6 more than Hakan, then Hakan will be minus. The total number of correct answers of Emine and Gülşen is 98. If Gülşen makes 98, Emine will be at least 0; otherwise, Emine will be minus.

As can be understood from Figure 15 and the dialogue, it is observed that Emel determined the quantities, discovered the quantitative relationship (the additive difference between the total number of correct answers), and she could determine a range with the estimation and control strategy for the number of correct answers that could be given as minimum and maximum in the second problem by interpreting the quantitative information obtained. In the solution of the third problem situation, Atakan made the following explanation upon the diagram he drew,

$A_{H}$ : There is something like this (By pointing to the sticks). Hakan lost 6 , and Ahmet won with +2 here. As the loss of Hakan and Ahmet is 4, between 98 and 94 should be 4 . It does not prove as 96-94=2.

In a similar manner, Atakan also determined the quantities and the relations between the quantities, and as it can also be seen in the explanations, he could interpret that the number of correct answers could not be found based on reasoning by expressing that the difference between the total number of correct answers that gave the quantitative information (between 94 and 96) and the additive difference $(-2+6=4)$ was not equal. On the other hand, the fact that the student made an estimation based on the data and tested his estimation also attracts attention. In the stage of assessment, both students checked the accuracy of the results they found. In this process, they could associate three problem situations that were related to each other and had the increasing level of difficulty with each other.

The solution performances, solution steps and quantitative reasoning skills of the students in the process of solving problems that contain the combination of the differences given in Figure 16 are presented in Figure 17.

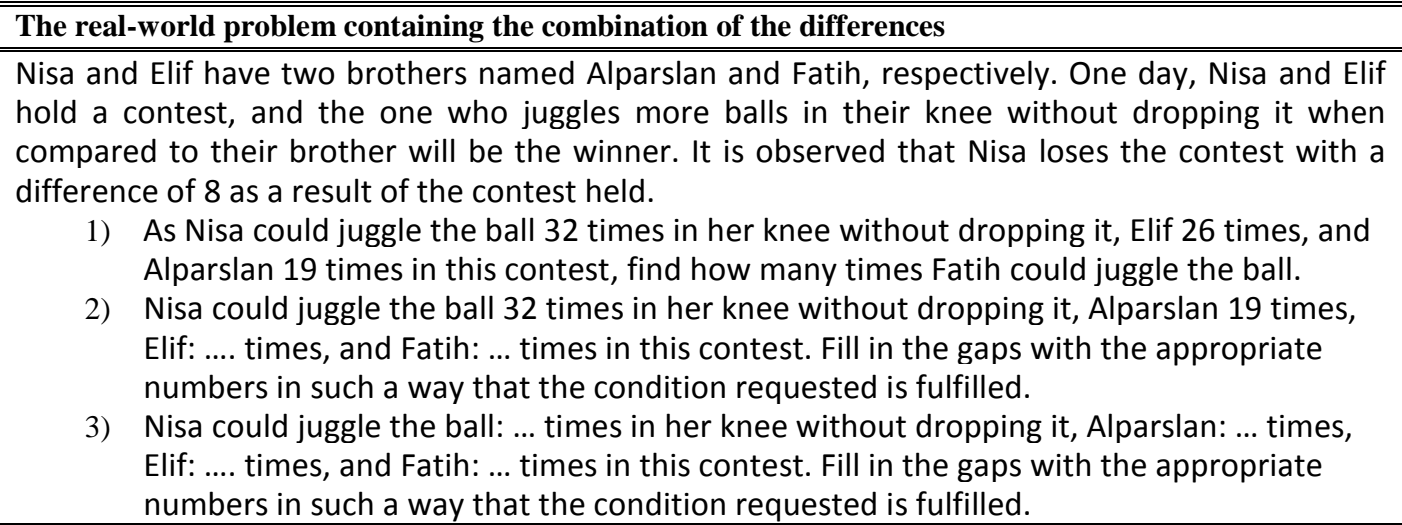

Figure 16. The real-world problem containing the combination of differences

As seen in Figure 17, Atakan and Emel could solve all three problems. While starting to solve the problems, both students expressed the problems with their own words and determined what was given and required. In the problem situations, students are primarily expected to become aware of the seven quantities (i.e. the scores of Nisa and her brother Alparslan, the scores of Elif and her brother Fatih, and the other quantities obtained from the two quantities, the difference between the scores of Nisa and Alparslan, the difference between the scores of Elif and her brother Fatih, and finally the new quantity, Nisa's claim that is the difference of the difference). In this process, it is important that the students first compare two differences in the context of quantitative reasoning, in other words, compare "the juggling score between the siblings" and "the score between the two friends" and discover the quantitative 
Tanışlı \& Dur - Çukurova Üniversitesi Eğitim Fakültesi Dergisi, 47(1), 2018, 60-108

relationship of the "difference of differences". Emel and Atakan realized this situation in all problems and showed the relationships they discovered by drawing a diagram.

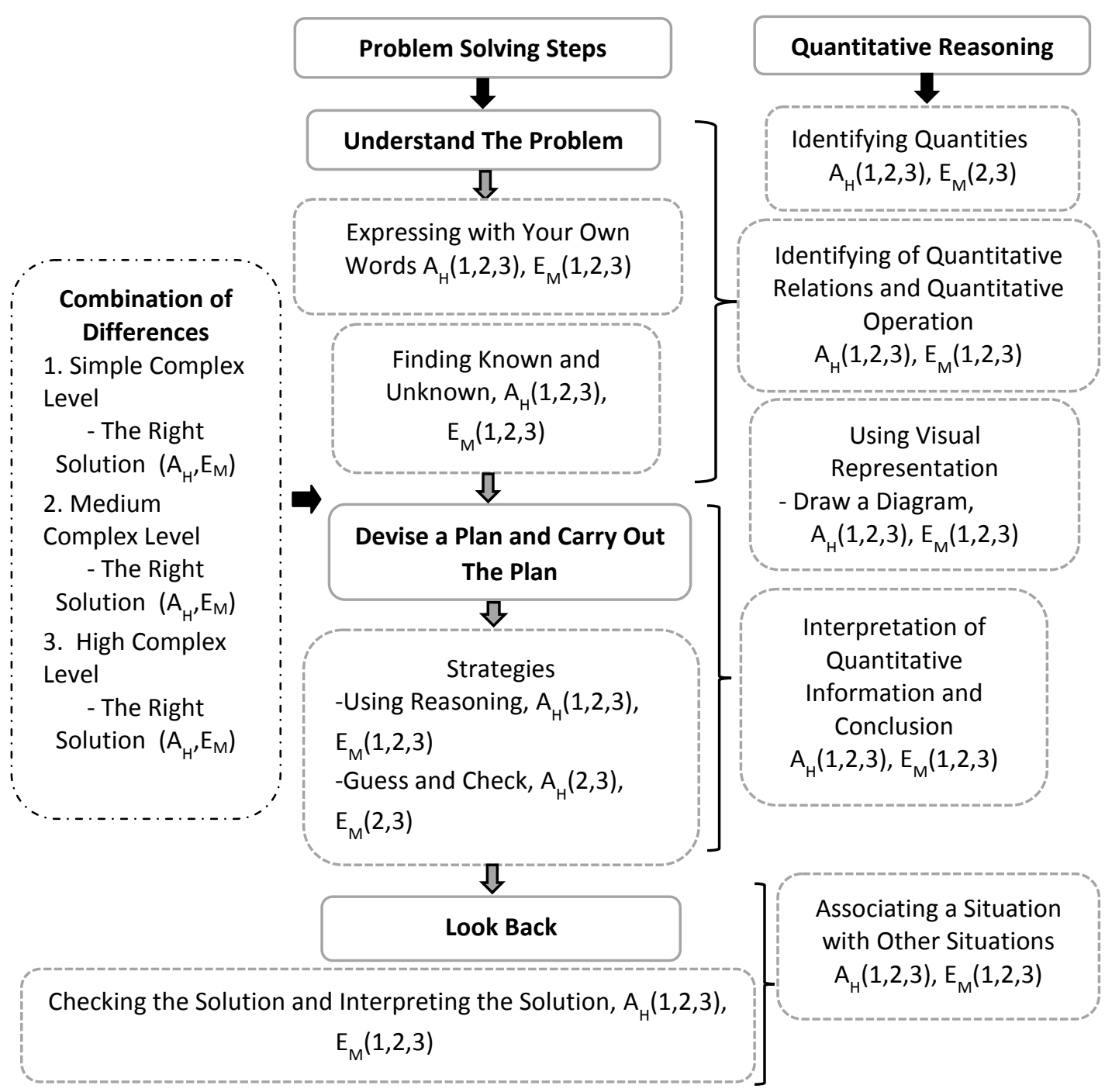

Figure 17. The solution processes and quantitative reasoning skills of the students in the process of solving a problem that contains the combination of the differences

As can be seen in Figure 18, Emel found how many times Fatih juggled the ball with a quantitative operation based on the difference of the differences between the number of ball juggling of the siblings, in other words, the new quantities obtained from two quantities, and their difference.

Atakan solved the same problem upon the diagram he drew by using the reasoning strategy as shown in Figure 19. 
Tanışı \& Dur - Çukurova Üniversitesi Eğitim Fakültesi Dergisi, 47(1), 2018, 60-108

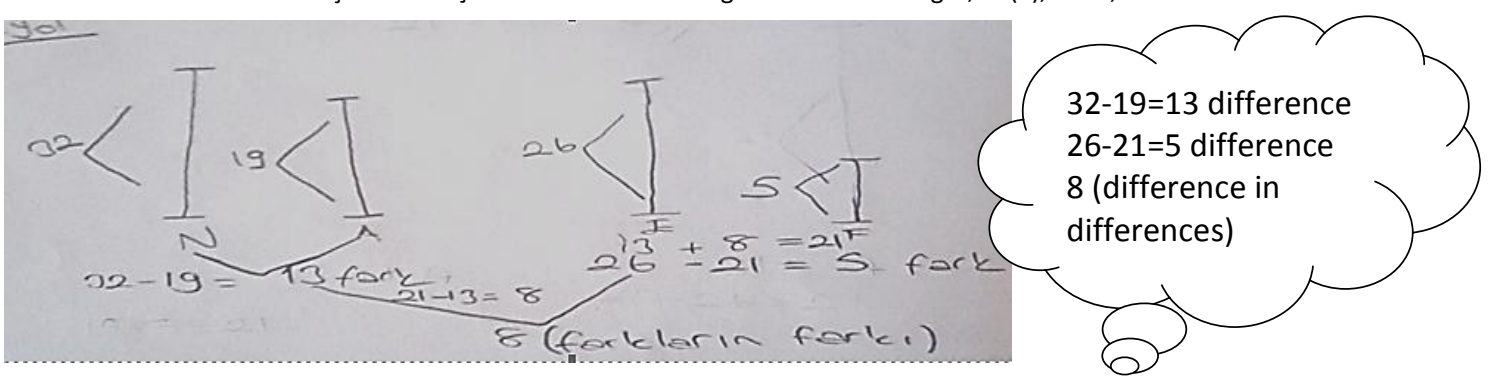

Figure 19. Atakan's solution

Reasoning, estimating and checking strategies were used in the second and third problem situations. For example, Emel explained the solution of the third problem as follows;

$E_{M}$ : I gave 29 to Nisa and 17 to Alparslan. The difference between them is 12 . As Elif won the competition with a difference of 8 points, she should first close the gap of 12 scores, and win with a difference of 8 scores. I gave 34 to Elif, and 14 to Fatih.

Res: Can other numbers be written to the gaps?

$\mathbf{E}_{\mathrm{M}}:$ Yes. This time Nisa has 42.

Res: Could the correct numbers of Elif and Nisa be equal?

$\mathbf{E}_{\mathrm{M}}$ : Yes. Here, it is asked who is the one that outscores his/her sibling most rather than who scores most. In my solution, Alparslan should score more, and Fatih a bit less, so that Elif can win.

Res: Is there any relation between the numbers that can be written to the gaps?

$\mathbf{E}_{\mathbf{M}}$ : All numbers can be written as long as the difference with which Elif outscored her sibling is 8 more than the difference with which Nisa outscored her sibling, and the difference with which Nisa and Alparslan outscored Elif and Fatih is minus 8.

Similarly, in the second problem, a comment such as "any number that fulfils the difference of 21 between Elif and Fatih can be written" was made on the ball juggling numbers of Elif and Fatih by using the difference of the differences between the number of ball juggling of Atakan siblings and considering the constant difference of 12 between the number of ball juggling of the two siblings. In all these processes, both students could conceptualize the quantities and the relationship between the quantities and interpret the quantitative information. In the assessment phase, both students could show the accuracy of the results and associate the three problem situations with each other.

The solution performances, solution steps and quantitative reasoning skills of the students in the process of solving the problems that contain a quantitative ratio given in Figure 20 are presented in Figure 21.

\section{The real-world problem containing a quantitative ratio}

1) There are different amounts of water in water canisters $A$ and Bat the beginning. One tap with the equal water discharge capacity is opened for each of these canisters to fill them fully. The followinginformation is given on the canisters and taps. The amount of water in canister $A$ is 36 liters some time later. In this case, the amount of water in canister $A$ is 4 times the amount of water in canister B. As canister B has 3 liters of water at the moment, how many liters of water are there in canister $A$ ?

2) Veysel can paint a flat in a building in 12 days alone. Hürriyet can paint another flat in this building (with the same shape and dimensions) in 15 days alone. After how many days will the painted parts of the flats be of equal dimensions as Hürriyet starts to paint her flat 2 days before Veysel?

Figure 20. The real-world problem containing a quantitative ratio 
Tanışlı \& Dur - Çukurova Üniversitesi Eğitim Fakültesi Dergisi, 47(1), 2018, 60-108

As can be seen in Figure 21, Atakan and Emel solved both problems successfully. When starting the problems, Atakan and Emel expressed the problem with their own words and determined what was given and required. In the first problem, the students became aware of four quantities (the amount of water present in canisters $A$ and $B$, and the amount of water in canisters $A$ and $B$ some time later). Furthermore, they discovered the multiplicative relation (quantitative ratio) as "the amount of water in canister A will be four times the amount of water in canister B at a later point in the future" and the additive relation (quantitative difference) as "the difference between the amount of water in canister B in the future and in the present time will be equal to the difference between the amount of water in canister $A$ in the future and present time". In this process, Emel showed the quantities and the relationship between the quantities upon the table.

Atakan and Emel used the strategy of reasoning in two problems in the stage of planning and implementation of the plan. For example, Emel explained the solution of the first problem upon the table she drew with the reasoning "Then, as A will be 4 times of $B ; 36: 4=9$ litres is the state of canister B some time later. Then 9 , and now 3 ; so, it is filled with $9-3=6$ litres of water. $36-6=30$ litres canister A."

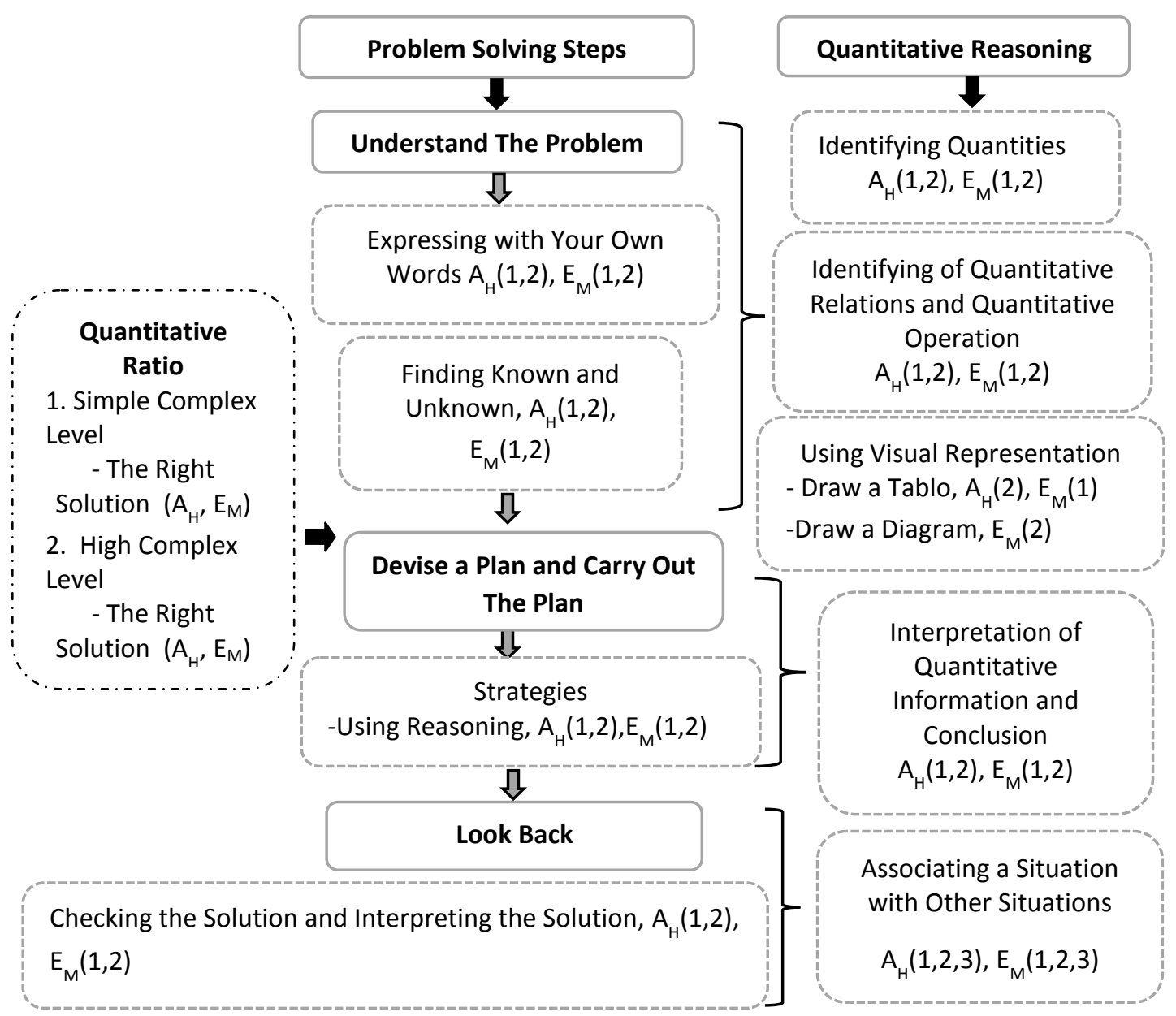

Figure 21. Solution processes and quantitative reasoning skills of the students in the process of solving the problem that contains a quantitative ratio

In the second problem, the students considered "Veysel and Hürriyet's painting speeds" and the fact that "Veysel is faster than Hürriyet" as two quantities, and they compared the painting speeds and discovered the multiplicative relation between the quantities considering the changes in quantities with 
respect to one another. Emel showed this process by drawing a diagram, while Atakan showed it by drawing a table.

In the stage of planning and implementing the plan, both students used the strategy of reasoning. For example, Emel explained the problem upon the diagram she drew with the following reasoning: "Veysel is faster than Hürriyet. The time ratio of Veysel to Hürriyet is $4 / 5$. And the speed ratio will be the exact opposite 5/4. If Hürriyet starts 2 days before at a speed of $4 / 4$, Veysel will make up this difference with a speed of $1 / 4$. As Hürriyet also works while Veysel is working, Veysel seems to be working at a speed of $1 / 4$, as Hürriyet works at a speed of $4 / 4$, and Veysel works at a speed of $5 / 4$, and the difference is $1 / 4 . "$

At the same time, Atakan solved the problem upon the table he drew as shown in Fig. 22, and he explained his solution as follows: "Veysel paints at $1 / 5$ shorter time. The speeds must be the exact opposite of the time. Because Veysel is using the time better. Hürriyet's speed is $4 / 4$, and Veysel's speed is $5 / 4$ as we used the same denominator. There is a difference of $1 / 4$ between them. Hürriyet started 2 days ago at a speed of $4 / 4$. If I assume each $1 / 4$ part as 2 , then the $4 / 4$ part is completed in 8 days."
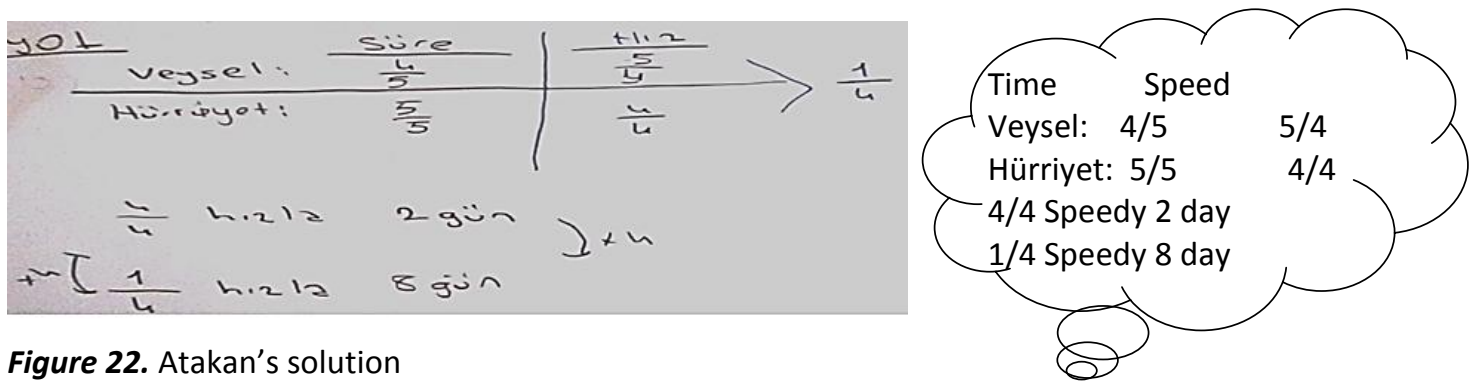

Figure 22. Atakan's solution

In the assessment stage, the two students checked the accuracy of the results and interpreted the solution.

\section{Discussion \& Conclusion}

This research, which was conducted on sixth-grade secondary school students but presents the clinical interviews of two focal students, attempts to determine the role of quantitative reasoning development in the problem-solving skill. As a result of the study, two important situations were revealed. The first one of these is that these skills of students can be developed with training provided on the development of quantitative reasoning pursuant to Thompson (1993)'s claim and as it is observed in certain studies (Smith \& Thompson, 2007; Ellis, 2007; Moore, 2010), while the other one is that problem-solving skills can also be developed together with this development(Moore, Carlson and Oehrtman, 2009; Moore and Carlson, 2012). When the mental activities of the students before and after the training were compared, many proofs were found shoving that this development was ensured. In the study, the real-world problems of four different types and at three levels of complexity of each type were presented to the students. While the simple complex level problems could generally be solved from all problem types before the training, the students had difficulty in solving the problems with the medium and high complexity level. In the problems that were solved, the students did not have any difficulty in solving the problems since the "answer" could generally be found as a result of arithmetic or algebraic calculations. In their solutions, they focused mainly on the numbers to be used in the problem, and they used more limited strategies by choosing the necessary arithmetic operations. Nevertheless, the students had cognitive difficulties when the same problem was transformed into a situation, in which it must be assessed in terms of quantitative relations, in other words, the numbers were pushed to the background, and first, the quantities and the relations between them should be focused on (Thompson, 1993). Since meaningless thinking styles emerge for the students after the meaning and purpose are lost in mathematics (Smith \& Thompson, 2007), the students were not able to cope with this complex situation and mainly used the trial and error strategy and performed meaningless operations from time to time. Sowder (1988) states that students make unfounded, meaningless debates about the selection of numbers and operations in their solutions when they do not pay attention to quantities and relations in problem situations. Therefore, in the study, this situation 
revealed by the students was also an indicator that students failed to make non-numerical inferences in relation to the problems, in other words, they were unaware of quantities and failed to make inferences with regard to quantitative relations (Thompson, 1993). This result is parallel to the findings of certain studies (Kabael \& Akın, 2016). At this point, it can be said that the fact that students more frequently encounter problem situations leading to a uniform outcome may be another reason for their having difficulty in such problems. Indeed, this situation attracts attention from the statements that students wrote in their diaries. For example, Atakan explained that he had difficulty in solving the given problem and that he had never encountered such a problem before as in Figure 25.

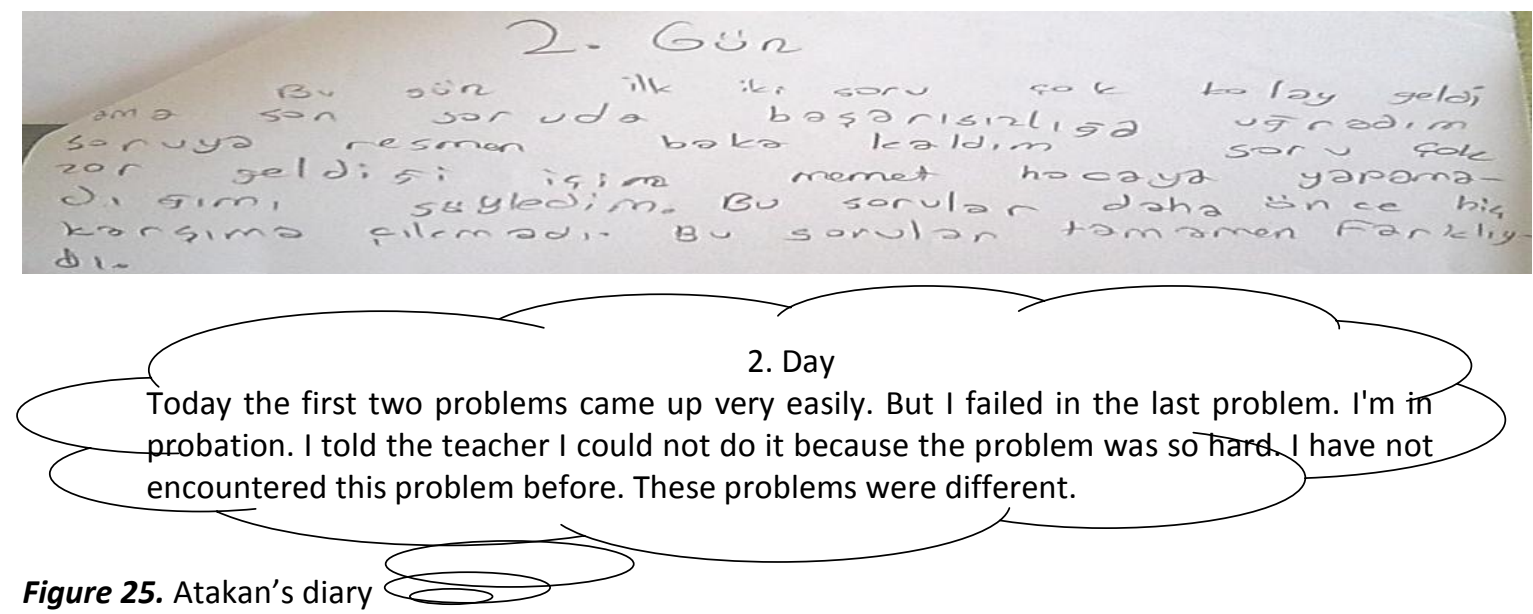

The changes observed in the students following the interviews made at the end of the teaching process gave rise to the idea that the approach of thinking upon quantities and quantitative relationships may be the focus of the problem-solving process because the teaching focused on the development of quantitative reasoning made a great difference in the problem-solving skills of the students. First of all, problems at all levels could be successfully solved using multiple ways and appropriate strategies. The most important development was achieved especially in the use of a visual representation (diagram). As it is also emphasized in many studies (Diezmann, \& English, 2001; Jonassen, 2003; Smith \& Thompson, 2007; Thompson, 2011), visual representations used in the stage of understanding and solving the problem are important tools in showing quantities and quantitative relations. These tools used in the teaching process in the study ensured that the students focused on the quantities between the information given in the problems and interpreted the quantitative relations, and as stated by Koedinger and Nathan (2004), developed different solutions, and its proof was observed in the final interviews. The fact that the students did not use visual representations in problem solutions before the training supports the idea that "all the difficulties in the transition from arithmetic to algebra result from the failure to representatively structure the problems" as it is stated in the studies of Bednarz, Radford, Janvier and Lepage (1992). Similarly, Smith and Thompson (2007) stated that when the verbal expressions used by students to define a problem situation lose their clarity, they are more comfortable with expressing these definitions with diagrams. It can be said that the reason behind the success of the students in problem solving is the development of quantitative reasoning skills, as claimed by Smith and Thompson (2007) because, in this process, the students understood the problems better since they focused on the quantities and the relations between the quantities irrespective of the numerical information in problem situations. They could also distinguish quantitative operations and arithmetic operations. This result also suggests that students who use quantitative reasoning skills effectively can solve problems in a short time by understanding them better and can use algebraic strategies effectively with the help of the quantitative reasoning skill, exhibit more flexible approaches in the problem-solving process and can perform time saving in parallel with the result of the study conducted by Kabael and Akın (2016). 
Tanışlı \& Dur - Çukurova Üniversitesi Eğitim Fakültesi Dergisi, 47(1), 2018, 60-108

The results of the study have shown that complex problem situations addressed when teaching is planned make a difference in the development of quantitative reasoning. It is therefore important to expose students to problem situations that are rich in terms of quantitative relationships that encourage students to think independently of numbers. Considering the importance of the thinking process rather than the result, a classroom environment in which students can express their thoughts freely should be provided, and students should be able to discuss "what is happening here?" In problem solving, it should be ensured that students focus on quantities and define quantities and quantitative relationships in the problem before the keywords (more, times, etc.). In this process, students should be encouraged to use visual representations such as diagrams, tables, figures. This study, which was carried out on the sixthgrade secondary school students, can make important contributions to the field in different terms by being conducted on primary school, high school students, or pre-service teachers with different designs. Furthermore, considering the role of textbooks in the learning and teaching process, research can be conducted on whether textbooks support the quantitative reasoning skill. 


\section{Türkçe Sürümü}

\section{Giriş}

Matematiksel bir problem genel olarak yaş ve sınıf düzeylerine bağlı olarak aritmetiksel ya da cebirsel olarak çözülebilir. Aritmetiksel bir çözümde, problemde var olan sayıları gösterme, bu sayılar arasındaki ilişkileri anlama, bu ilişkilere bağlı olarak uygun sayı çiftleri arasında doğru aritmetiksel işlemi uygulama, yapılan işlemin amacını anlama, diğer işlemlerle ilişkilendirme söz konusudur (Blanton, 2008;NCTM, 2000). Cebirsel bir çözüm ise, bilinmeyen içeren denklemi yazma ve bu denklemi çözmeyi kapsamaktadır (Van Ameron, 2002). Diğer yandan matematiksel bir problem, nicelikler ve nicelikler arasındaki ilişkiler üzerine odaklanarak da çözülebilir ki bu yaklaşım nicel muhakeme olarak adlandırılmaktadır (Smith \& Thompson, 2007).

Nicel muhakeme nicelikleri, nicelikler arası ilişkileri ve bu ilişkilerden oluşan yeni nicelikleri içeren bir yapıdaki durumun analizidir (Thompson, 1988). Nicel muhakemenin en karakteristik özelliği sayıların ve sayısal ilişkilerin ya da değişkenlerin önem bakımından ikinci sırada yer almasıdır. Problem durumları analiz edilirken öncelikle nicelikler üzerine sayısal olmayan çıkarımlar yapılmakta ve bu niceliklerin problem durumu ile nasıl bir ilişkisi olduğu ortaya koyulmaktadır. Daha sonra sayılar ve sayılar arası ilişkiler ve niceliğin değerini hesaplamaya yönelik uygun sayısal işlemler göz önüne alınmaktadır (Thompson, 1993; Thompson, 2011). Nicel bilgilerin bu şekilde analiz edilmesi öğrencilerin problemde sonuca ulaşmak için hangi yöntemlerin ve stratejilerin kullanılacağına karar vermelerine yardımcı olmaktadır (Dwyer, Gallagher, Levin, \& Morley, 2003). Bu bağlamda nicel muhakemenin problem çözmeye ışık tutan ve çözüm sürecini anlamlandıran bir teori olduğu söylenebilir.

\section{Problem Çözme ve Nicel Muhakeme}

Problem çözme okulöncesinden itibaren geliştirilmesi hedeflenen en temel becerilerden biridir (CCSM, 2010; NCTM, 2000). Problem çözme bir düşünme yoludur, aynı zamanda bir süreçtir. Literatürde bu sürecin adımlarını açıklayan çeşitli modeller söz konusudur. Polya'nın (1945), Schoenfeld (1985)'in, Verschaffel, De Corte, Lasure, Vaerenbergh, Bogaerts, ve Ratinckx (1999)'nin modelleri bunlardan bazılarıdır. Bu çalışma kapsamında benimsenen Polya (1945)'nın modeli problemin anlaşılması, çözüm için plan hazırlanması, planın uygulanması ve çözümün değerlendirilmesi şeklinde dört aşamadan oluşmaktadır. Bu süreçte problemin çözüm yolu olarak da ifade edilen sistematik liste yapma, tahmin ve kontrol, örüntü arama, şekil-diyagram çizme, tablo yapma gibi çeşitli stratejiler de kullanılmaktadır (Van de Walle, Karp \& Bay-Williams, 2016). Nicel muhakeme problem çözme sürecinin tüm aşamalarını etkileyen ve süreci anlamlandıran bir yaklaşımdır. Nicel muhakeme gelişiminde önemli yer tutan kavramlardan biri ise gerçek yaşam deneyimlerine dayalı problemlerdir. Smith ve Thompson (2007), öğrencilerin nicel muhakeme becerisinin geliştirilmesi için, ilkokul ve ortaokul matematiği düzeyinde "problem" kavramının yeniden düşünülmesi gerektiğini belirtirler. Onlara göre problem kavramı öğrencilerin nicelikler arası ilişkiler üzerine muhakeme yaptıkları ve kavramsallaştırdıkları gerçek yaşam durumlarıdır.

Gerçek yaşam problemlerinin çözümünde nicel muhakeme becerisinin gelişimine odaklanılıyorsa, öncelikle sayısal çözüm ya da değişken atanması ve denklem çözümü gibi rutin işlemler izlenmez. Aritmetik çözümde odak noktası sayılar ve sayılar arası ilişkiler, cebirsel çözümde ilişkilerin sembole dönüştürülmesi iken nicel çözümde nicel ilişkilerin ifade edilmesi ve nicel ilişkilerle çalışılması üzerinedir (Smith \& Thompson, 2007). Buradaki temel yaklaşım ise nicel muhakeme yapan kişinin problem durumunu anlaması, bu bağlamda nicelikleri belirleyerek problem durumundaki nicelikler arasındaki ilişkilere odaklanması önemlidir. Dolayısıyla nicel muhakemede ön planda olan kavram nicelik kavramıdır. Thompson (1988)'a göre nicelik, nesnenin ölçülebilen özelliğinin zihinde resmedilmesi ya da canlandırımasıdır. Diğer bir değişle, nicelik kişinin bir nesnenin ölçülebilme özelliğini anlayabilecek 
şekilde o nesnenin niteliğini düşünerek zihinde oluşturduğu bir kavramdır. Ancak nicelikler hakkında düşünmek için niceliklerin ölçülmesine ya da onların ölçüm sonuçlarının sayısal değerinin bilinmesine gerek yoktur.

Problemi anlama sürecinde düşünülmesi önemli kavramlardan biri de nicel işlemlerdir. Nicel işlemler zihinde var olan iki nicelikten yeni bir nicelik oluşumunu sağlayan zihinsel işlemlerdir. Ayrıca nicel işlem sonucunda oluşan yeni nicelik de, zihinde var olan iki nicelik arasındaki ilişkiyi göstermektedir (Thompson, 1993; Smith \& Thompson, 2007). Nicel işlemler, aritmetik işlemlerle aynı değildir, ancak niceliğin değeri bilindiğinde ilişkilidir. Yani aritmetik işlemler bir niceliğe değer teşkil etmektedir (Smith \& Thompson, 2007). Problemin çözümü için plan yapma ve çözümü uygulama sürecinde ise seçilen stratejiler ile nicel bilginin yorumlanarak sonuca ulaşması, devam eden süreçte de elde edilen sonucun problem durumu ile değerlendirmesi gereklidir.

Problem çözme üzerine yapılan araştırmalar her sınıf düzeydeki öğrencilerin problemi anlama (Herscovics \& Kieran, 1980; Kamal \& Ramzi, 2000; Stacey \& MacGregor 1999), sözel problemi matematiksel dile dönüştürme (Lochhead, 1988), problemi yorumlama (French, 2002), uygun stratejiyi kullanma (Verschaffel, De Corte \& Lasure, 1999) gibi çeşitli durumlarda güçlükler yaşadıklarını göstermektedir. Öğrenciler verilen bir problemde salt sayısal değerlere, aritmetik işlemlere ya da bilinmeyenlere sembol atayarak sadece cebirsel işlemlere odaklandıkları ve işlemsel boyutun ötesine geçemedikleri zaman problem çözme sürecinde zorlanabilmektedir (Mayer, Lewis, \& Hegarthy, 1992; Smith \& Thompson, 2007; Thompson, 1993). Tambychik ve Meerah (2010) ise öğrencilerin problem çözme sürecinde zorlanmalarının nedenini öğrencilerin sayı olgusu, aritmetik beceriler, kavramsal ve işlemsel bilgi becerileri, dil becerileri, görsel ve uzamsal beceriler gibi matematiksel becerilere sahip olmamalarından kaynaklanabileceğini ifade etmişlerdir. Çünkü öğrenciler problem çözme süreci boyunca pek çok matematiksel kavram ve beceriyi uygulamak ve bütünleştirmekle yükümlüdürler. Thompson (1988)' da problem çözme sürecinde yaşanılan güçlükleri erken yaşlardan itibaren daha temel, somut, nicelikler arasındaki ilişkileri göz önüne alan ve aritmetiksel ya da cebirsel yöntemlerden daha informal olarak görülen nicel muhakeme becerisinin kazandırılamamasından yaşanabileceğini ifade etmiştir. Thompson'a göre nicel muhakeme kazanımı hem aritmetikte sayısal ifadelerin ve işlemlerin, cebirde ise sembolik ifadelerin ve işlemlerin anlamlandırılmasına hem de problem çözme becerisinin gelişimine katkı sağlamaktadır. Bu bağlamda yaptığı çalışmalarla da nicel muhakeme becerisinin gelişimiyle problem çözme becerisinin gelişiminin sağlanabildiğini desteklemiştir (Smith \& Thompson, 2007).

Yapılan bazı çalışma sonuçları da nicel muhakeme becerisinin gelişimiyle öğrencilerin karmaşık problemleri çözüm sürecinde yaşadıkları bilişsel güçlüklerin azalabileceğini, kavramların anlaşılmasının ve içselleştirilmesinin sağlanabileceğini göstermektedir (Ellis, 2007; Moore, 2010; Smith \& Thompson, 2007; Thompson, 1988; Thompson, 1993). Çünkü nicel muhakemeye dayalı problem çözümleri öğrencileri çok yönlü çıkarımlarla ezbere dayanan kalıplaşmış çözüm yollarından uzaklaştırarak kavramsal bir öğrenmeye yol açmaktadır. Örneğin bu düşünceyi destekleyen Ellis (2007) tarafından yapılan araştırmada deney ve kontrol grubu olarak belirlenmiş iki grup ortaokul öğrencilerinin genelleme bağlamında nicel muhakeme becerileri incelenmiştir. Araştırma sonunda nicelikler ve nicelikler arası ilişkiye dayalı öğretim yapılan gruptaki öğrencilerin gerçek yaşam problemlerinde istenen ilişkileri anlamlı bir şekilde genelleyebildikleri belirlenmiştir. Moore ve Carlson (2012) tarafından üniversite öğrencileri üzerinde gerçekleştirilen bir çalışmada ise gerçek yaşam problemlerini çözme sürecinde nicel muhakeme becerisi gelişmiş öğrencilerin problemleri daha anlamlı çözebildikleri görülmüştür. Benzer şekilde Moore, Carlson ve Oehrtman (2009) tarafından üniversite öğrencileri üzerinde gerçekleştirilen bir başka çalışmada ise nicel muhakemenin problem çözmede etkili olduğu sonucuna ulaşılmıştır. Kabael ve Akın (2016) tarafından yapılan ve yedinci sınıf öğrencilerinin cebirsel sözel problemleri çözerken kullandıkları stratejileri ve nicel muhakeme becerilerini araştırdıkları çalışmalarında da problem çözme sürecinde hem aritmetiksel hem de cebirsel stratejilerin etkili kullanılabilmesinde nicel muhakeme becerisinin önemli rol oynadığı vurgusu yapılmıştır.

Illkokuldan itibaren devam eden tüm düzeylerde nicel muhakeme açısından zengin öğretim programları problem çözme ve nicel muhakeme becerilerinin çok yönlü gelişmesinde oldukça önemlidir. 
Tanışlı \& Dur - Çukurova Üniversitesi Eğitim Fakültesi Dergisi, 47(1), 2018, 60-108

Örneğin Çin ve Singapur gibi ülkelerin matematik dersi öğretim programları incelendiğinde programların nicel muhakemeyi desteklediği ve bu ülkelerin öğrencilerinin de problem çözme becerilerinin gelişmiş olduğu dikkati çekmektedir (Cai, Ng \& Moyer, 2011). Türkiye'de ise matematik dersi öğretim programlarında doğrudan nicel muhakemeye vurgu yapılmamakta sadece problem çözme sürecinde öğrencilerin düşünme ve akıl yürütmelerini rahatıkla ifade edebilmelerinin, başkalarının matematiksel akıl yürütmelerindeki eksiklikleri ya da boşlukları görebilmelerinin beklenildiği vurgulanmaktadır (MEB, 2017). Türkiye'de her sınıf düzeyinde problem çözme bağlamında yapılan pek çok çalışmada da öğrencilerin genel olarak problem çözme sürecinde güçlük yaşadığı ifade edilmektedir (örn., Bayazıt, 2013; Çelik \& Güler, 2015; Şener \& Bulut, 2015). Problem çözme sürecine etki eden faktörlerin incelendiği çeşitli çalışmalar da bulunmaktadır (örn., Türnüklü \& Yeşildere, 2005). Ancak bu çalışmalar incelendiğinde problem çözme sürecinde nicel muhakemenin rolünün araştırılmadığına rastlanmış sadece yedinci sınıf öğrencilerin sözel cebirsel problemleri çözme sürecindeki nicel muhakeme becerilerinin araştırıldığı bir çalışmaya ulaşılmışır (Kabael \& Akın, 2016). Oysa ki Thompson (1988)'ın da iddia ettiği gibi, somut, sezgisel ve kendine özgü modelleri olan nicel muhakeme problem çözme öğretiminde alternatif bir yaklaşım olarak kullanılabilmektedir. Bu düşüncelerden hareketle Türkiye'de öğrencilerin nicel muhakeme becerilerinin ne düzeyde olduğu ve bu becerinin gelişimi üzerine öğretim yapıldığı taktirde öğrencilerin problem çözme becerilerinde nasıl bir değişim olabileceği bu çalışmanın yapılmasını gerekli kılmıştır.

Araştırmanın genel amacı, ortaokul altıncı sınıfa devam eden iki öğrencinin nicel muhakeme gelişimlerinin gerçek yaşam problemlerini çözebilme becerilerindeki rolünü belirlemektir. Bu amaç doğrultusunda aşağıdaki iki soruya yanıt aranmıştır.

3. Ortaokul altıncı sınıfa devam eden iki öğrenci gerçek yaşam problemlerini öğretim öncesi nasıl çözmekte ve yorumlamaktadır?

4. Ortaokul altıncı sınıfa devam eden iki öğrenci gerçek yaşam problemlerini öğretim sonrası nasıl çözmekte ve yorumlamaktadır?

Çalışma sadece öğretim öncesi ve sonrası klinik görüşmeler ile sınırlandırılmıştır. Çalışmanın problem çözme sürecinde öğrencilerin nicelikleri belirleyebilme, nicelikler arası ilişkileri keşfedebilme ile nicel bilgiyi yorumlayabilme ve sonuç çıkarabilme becerilerinin başta ve sonda nasıl olduğunu ortaya çıkarma bakımından önemli olduğu düşünülmektedir. Ayrıca çalışmada kullanılan problemlerin ve problem çözme sürecinde öğrencilerin izledikleri çözüm yollarının öğretmenlere, öğretmen adaylarına ve matematik eğitimcilerine örnek teşkil etmesi açısından da çalışma önemlidir.

\section{Yöntem}

\section{Araştırma Modeli}

Bu araştırmada öğretim deneyi modeli benimsenmiştir (Cobb \& Steffe, 1983). Bu modelin seçilme nedeni, öğrencilerin nicel muhakeme gelişimleriyle problem çözme becerilerinin öğretim öncesine ve sonrasına göre nasıl bir değişim gösterdiğini araştırmacıların görebilmesidir (Steffe, 1991). Bu bağlamda araştırmacılardan biri öğretmen olarak ortamda yer almış ve araştırmayı okul ya da sınıf ortamında öğretme faaliyetlerini sürdürdüğü sırada yapmıştır.

Öğretimler beş hafta ve 10 ders saatinde altıncı sınıf öğrencileri üzerinde gerçekleştirilmiştir. Bu süreçte problem çözmeye ilişkin bir öğretim gerçekleştirilmiş (Van De Walle et all, 2016), bu bağlamda Polya (1945)'nın dört aşamalı problem çözme modeli kullanılmıştır. Öğretim sürecinde Smith ve Thompson (2007) çalışmalarında kullandıkları problemlere benzer farklı içerikte ve düzeyde (basitten karmaşığa) nicel muhakeme gerektiren gerçek yaşam problemlerinin yer aldığı etkinlikler oluşturulmuştur. Bu süreçte araştırmacı öncelikle problemleri bireysel ya da küçük grup çalışmaları ile çözdürmüş sonra çözümlerini ve düşüncelerini paylaşmalarını sağlayacak ortamlar oluşturarak, "Bulduğun neyi ifade ediyor?", "Ne bulmaya çalışıyorsun?" gibi sorular yöneltmiştir. Aynı zamanda öğrencilerini iyi bir şekilde dinleme eğilimi sergilemiştir. Sınıf içi etkileşimde öğrencilerin problem çözme sürecinde nicelikleri açıklarken görsel temsil kullanmaları muhakeme açısından önemlidir. Bu noktada 
araştırmacı öğrencilerden açıklamak istedikleri tanımlamaları diyagramlar, şekiller, tablo gibi temsiller kullanarak ifade etmelerini istemiştir (Smith \& Thompson, 2007). Aynı zamanda problem çözme sürecinde öğrencilerini farklı stratejiler kullanma yönünde teşvik etmiştir.

\section{Katılımcılar}

Araştırmanın katılımcıları, Türkiye'de bir il merkezinde yer alan bir ortaokulda altıncı sınıfa devam eden öğrenciler arasından seçilen iki odak öğrencidir. Öğrencilerin seçiminde amaçlı örneklem yöntemlerinden ölçüt örneklem kullanılmış (Yıldırım \& Şimşek, 2013) ve öğrencilerin matematikteki başarı düzeyleri ölçüt olarak ele alınmıştır. Bu bağlamda matematik dersi karne notları, okulda yapılan deneme sınavlarından alınan sonuçlar ve öğretmen görüşü dikkate alınarak, başarı düzeyi yüksek bir erkek öğrenci ile başarı düzeyi orta olan bir kız öğrenci araştırma kapsamında gönüllülük esasına dayalı olarak seçilmiştir. Niceliksel muhakeme yapabilme becerisi kazanmanın aslında uzun bir süre alması ve katılımcılarda belli bir hazırbulunuşluk düzeyi gerektirmesi nedeniyle düşük başarı düzeyine sahip öğrenciler bu çalışmada katılımcılar olarak tercih edilmemiştir.

\section{Verilerin Toplanması}

Araştırmanın temel verileri öğretim öncesi ve sonrası uygulanan klinik görüşme tekniği ile toplanmıştır (Clement, 2000, s.547). Bunun yanı sıra öğrenci çalışma yapraklarından, öğrenci günlüklerinden, araştırmacının günlüğünden destek veri olarak da yararlanılmıştır. Ön ve son klinik görüşme soruları için öğrencilerin nicel muhakeme yapabilme becerilerini ortaya çıkartabilecek nicel fark, karmaşık toplamsal durumlar, farkların kombinasyonu ve nicel oran türünde gerçek yaşam problemleri oluşturulmuştur. Bu süreçte Smith ve Thompson (2007)'nın çalışmalarındaki problemlerden yararlanılmıştır.Nicel fark içeren problem durumlarında iki niceliğin toplamsal olarak karşılaştırılması sonucu, nicel oran içeren problem durumlarında ise iki niceliğin çarpımsal olarak karşılaştırılması sonucu yeni bir niceliğin elde edilmesi söz konusudur. Karmaşık toplamsal durum içeren problem durumları bir ya da daha fazla nicel fark içerirken, ilişkisel karmaşık durum içeren problem durumlarında ise en az altı nicelik ve üç nicel işlem söz konusudur (Smith \& Thompson, 2007).

Hazırlanan klinik görüşme soruları uzman iki matematik eğitimcisinin görüşüne sunulmuştur. Daha sonra sorularının anlaşılırlığını test etmek ve sonda soruları da geliştirebilmek amacıyla altıncı sınıfa devam eden orta başarı düzeyine sahip gönüllü bir öğrenci üzerinde pilot çalışması gerçekleştirilmiştir ve sorular üzerinde gerekli düzeltmeler yapılmıştır. Klinik görüşmeler ise, bir araştırmacı tarafından yürütülmüş ve bir öğrenci ile görüşme, günde ortalama 30-40 dakikayı geçmeyecek şekilde dört günde tamamlanmıştır.

\section{Verilerin Analizi}

Araştırmada verilerin analizinde tematik analiz yöntemi kullanılmıştır. Tematik analizde temalar ve örüntüler veri içinde çıkarılabileceği gibi çeşitli modellerde kullanılan mevcut temalardan da yararlanılabilir (Liamputtong, 2009). Bu araştırmada da kodlar ve temalar problem çözme aşamalarıyla ve nicel muhakeme göstergeleriyle ilişkilendirilmiş ve Şekil 1'de sunulan süreç oluşturulmuştur. 


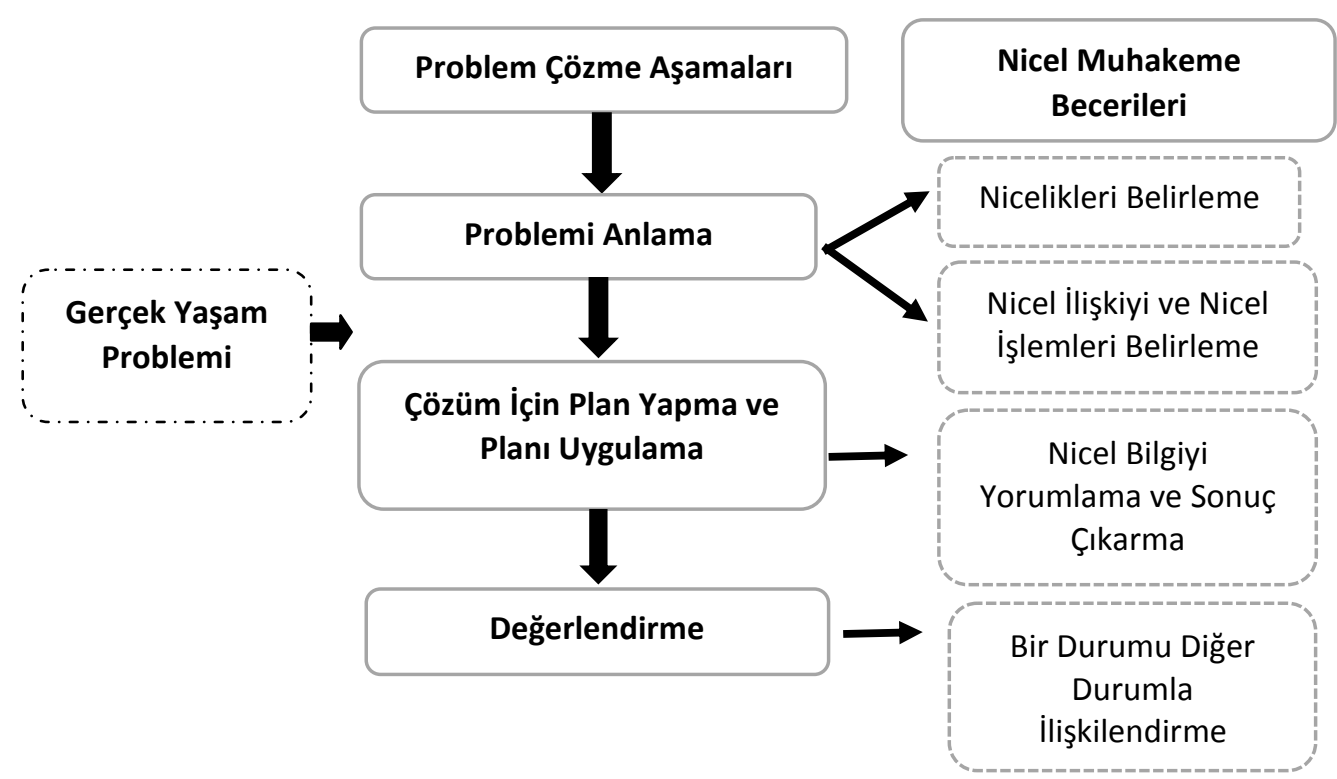

Şekil 1.Problem çözme süreci ile nicel muhakeme becerileri ilişkisi

Analiz süreci iki adımda gerçekleştirilmiştir. Öncelikle görüşmelerden, çalışma yapraklarından, öğrenci ve araştırmacı günlüklerinden elde edilen verilerin dökümleri yapılmıştır. Daha sonra veriler tekrar tekrar okunarak katılımcılar tarafından ifade edilen düşünceler anlamlandııılmaya çalışılmıştır. ikinci adımda ise kodlamaya geçilmiştir. Kodlama sürecinde her problem türü ayrı ayrı değerlendirilmiş ve öğrencilerin çözüm süreçleri incelenmiştir. Eğer öğrenci problemi "kendi cümleleriyle ifade edebiliyorsa" ve "problemde verilen ve istenilenleri tespit edebiliyorsa" bu ifadeler kod olarak ele alınmış ve "problemi anlama" alt teması altında toplanmışıı. Daha sonra öğrencinin kullandığı "stratejiler" diğer kodu oluşturmuş ve bu kodda "çözüm için plan yapma ve çözümü uygulama" alt teması ile tanımlanmıştır. Son olarak öğrenci "çözüm sonucunu kontrol edip yorumlayabiliyorlarsa" bu da "değerlendirme" alt teması altında ele alınmıştır. Tanımlanan tüm alt temalar ise "problem çözme süreci" teması ile ifade edilmiştir. Diğer yandan problemi anlama aşamasında, eğer öğrenci problem durumunda "nicelikleri belirleyebiliyorsa", "nicel ilişkileri ve nicel işlemleri ifade edebiliyorsa" ve bu ilişkileri "görsel temsil" ile ifade edebiliyorsa, çözüm için plan yapma ve çözümü uygulama aşamasında "nicel bilgileri yorumlayıp sonuç çıkarabiliyorsa" ve değerlendirme aşamasında ise "problemdeki bir durumu başka bir problemdeki durumla ilişkilendiriyorsa" tüm bu ifadeler kod olarak ele alınmış ve "nicel muhakeme becerileri" teması ile tanımlanmıştır.

Kodlama ve temalaştırma süreci araştırmacı ve matematik eğitiminde uzman biri tarafından birbirinden bağımsız olarak yürütülmüş ve güvenirlilik hesaplaması yapılarak \%80 güvenirlik sağlanmıştır (Miles \& Huberman, 1994, s. 64). Kodlar ve temalar bulgularda şekillerle sunulmuş, öğrenciler ise takma isimlerinin (Atakan ve Emel) baş harfleri ile başarı düzeyleri de yüksek için " $Y$ " ve orta için " $O$ " indisleri kullanılarak temsil edilmiştir. Ayrıca şekillerde basitten karmaşığa problemlerin güçlük derecelerini temsilen sırasıyla basit için 1, orta için 2 ve yüksek için 3 rakamları kullanılmışır.

\section{Bulgular}

Öğretim Öncesi íki Öğrencinin Nicel Fark, Karmaşık Toplamsal Durumlar, Farkların Kombinasyonu ve Nicel Oran Türündeki Problemleri Çözme Süreçleri ve Nicel Muhakeme Becerileri

Nicel fark içeren Şekil 2'de sunulan gerçek yaşam problemlerini çözme sürecinde öğrencilerin çözüm performansları, çözüm aşamaları ve nicel muhakeme becerileri Şekil 3'te verilmiştir. 


\section{Nicel fark içeren gerçek yaşam problemi}

Eskişehirspor, Trabzonspor ve Galatasaray futbol takımlarının yaptıkları maçlarda birbirlerine attıkları gollere ilişkin şu bilgiler verilmektedir.

1) Eskişehirspor 5 gol Galatasaray'a; 4 gol Trabzonspor'a; Galatasaray 2 gol Eskişehirspor'a; 3 gol Trabzonspor'a; Trabzonspor ise 1 gol Eskişehirspor'a; 6 gol Galatasaray'a atmıştır. Verilen bilgilere göre Trabzonspor un başlangıçtaki gol averaj durumuyla son durumdaki gol averaj durumunu kıyaslayınız.

2) Eskişehirspor 4 gol Galatasaray'a, 7 gol Trabzonspor'a; Galatasaray 1 gol Eskişehirspor'a, 2 gol Trabzonspor'a; Trabzonspor ise Eskişehirspor'a 3 gol atıyor ve maçların sonunda ilk durumuna göre 5 fazla gol averajına sahip oluyor. Buna göre Trabzonspor'un Galatasaray'a kaç gol attığını bulunuz.

3) Eskişehirspor --- gol Galatasaray'a; --- gol Trabzonspor'a, Galatasaray --- gol Eskişehirspor'a; -- gol Trabzonspor'a, Trabzonspor ise --- gol Eskişehirspor'a; --- gol Galatasaray'a atmıştır. Maçların sonunda Trabzonspor'un gol averajının ilk durumdaki gol averajına göre 2 eksik olacak şekilde boşlukları düzenleyiniz.

Şekil 2. Nicel fark içeren gerçek yaşam problemi

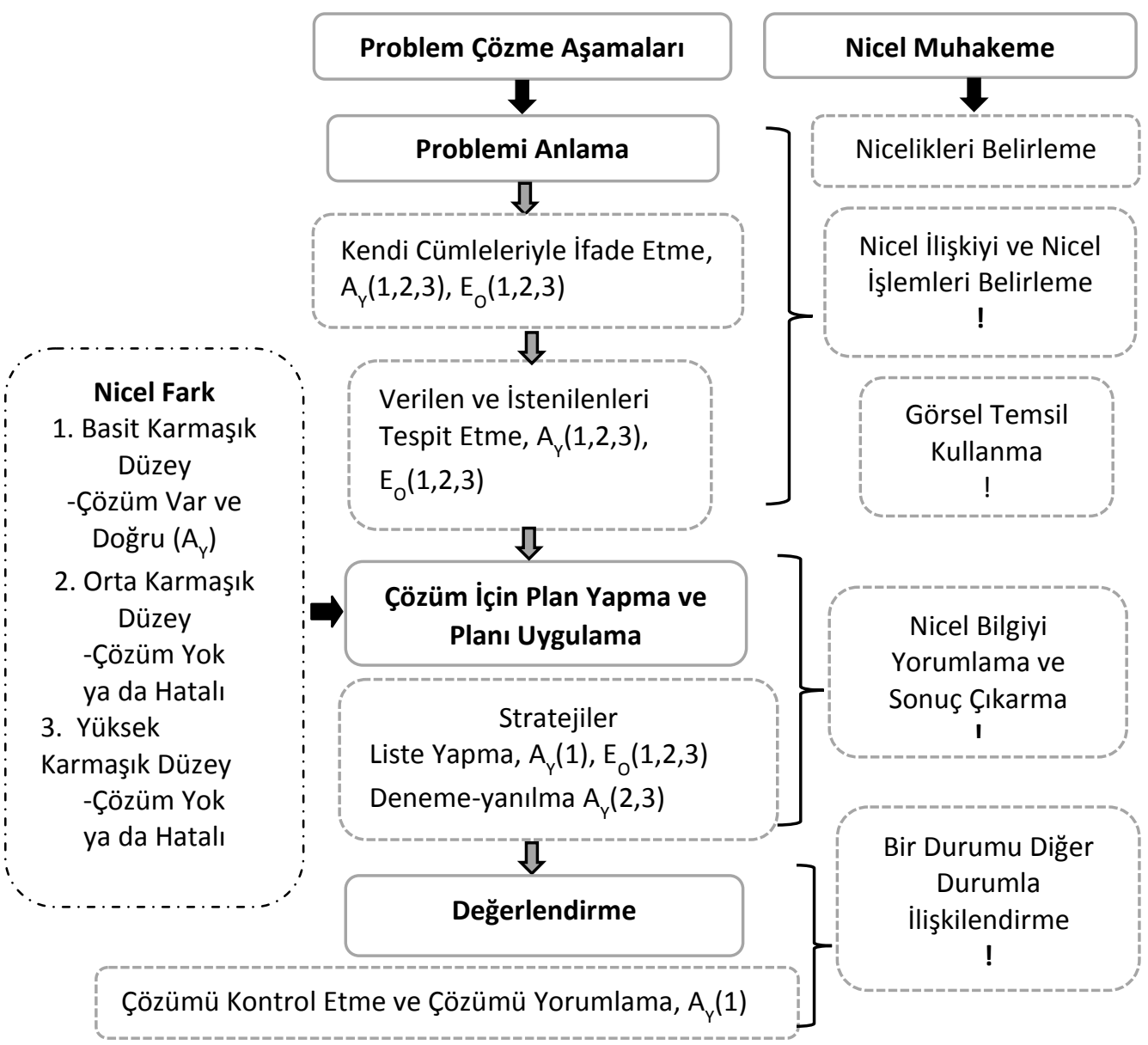

Şekil 3. Nicel fark içeren problemleri çözme sürecinde öğrencilerin çözüm süreçleri ve nicel muhakeme becerileri

Şekil 3'te görüldüğü gibi, öğrencilerin çözüm performanslarına bakıldığında sadece basit karmaşık düzeyde verilen problem Atakan tarafından çözülebilmiştir. Nicel fark içeren gerçek yaşam 
problemlerinin çözümüne başlarken öncelikle Atakan ve Emel problemleri kendi cümleleriyle ifade ederek, verilen ve istenilenleri belirlemişlerdir. Bu süreçte iki öğrencide problemde "atılan gol" ve "yenilen gol" olarak nicelikleri fark etmiştir. Ancak "yenilen ve atılan goller arasındaki toplamsal farkı" ya da "gol averajlarının nasıl değiştiği" ile ilgili nicel ilişkileri açıklamada ikisi de yetersiz kalmış, bu durum onların problem çözümlerine yansımıştır. Örneğin Emel plan yapma ve planı uygulama aşamasında üç problemin çözümünde liste yapma stratejisini (bir duruma ait olasılıkların listelenmesi) kullanmış ancak problemleri çözmede başarılı olamamıştır. Emel nicel ilişkiyi keşfedemediği için diğer bir değişle nicel farkı tam olarak anlamlandıramadığı için aşağıda görüldüğü gibi, atılan ve yenilen gol sayıları arasında anlamsız aritmetiksel işlemler gerçekleştirmiştir. Atakan ise, plan yapma ve planı uygulama aşamasında basit karmaşık düzeydeki problemin çözümünde liste yapma stratejisini kullanmış, direk sayılara odaklanarak "4 gol yedi, 3 gol yedi, 7 gol attı. 4+3=7-7=0" aritmetik işlemiyle doğru sonuca ulaşmıştır. Değerlendirme aşamasında ise çözümün doğruluğunu kontrol ederek, çözümü yorumlamıştır. Ancak Atakan birinci problemde başarılı olsa da ve problemde nicelikleri belirleyebilse de nicel muhakeme yapamadığından birinciyle ilişkili olan ikinci problemde "Trabzonspor'un yediği ve attığı goller arasındaki toplamsal farkı" bulmada yani nicel ilişkiyi keşfetmede ve "ilk duruma göre 5 fazla gol averajı" durumunu yorumlamada zorlanmıştır. Benzer zorluğu üçüncü problemde de yaşamış, "gol averajının ilk duruma göre 2 eksik olma durumunu" açıklayamamış ve bu problemlerin çözümünde deneme yanılma stratejisini (rastgele anlamsız aritmetik işlemler yapma) kullanmıştır.

Şekil 4'te verilen karmaşık toplamsal durum içeren problemleri çözme sürecinde öğrencilerin çözüm performansları, çözüm aşamaları ve nicel muhakeme becerileri Şekil 5'te verilmiştir.

\section{Karmaşık toplamsal durum içeren gerçek yaşam problemi}

Bir üniversitede $\left(S_{1}\right.$ ve $\left.S_{2}\right)$ ve $\left(M_{1}\right.$ ve $\left.M_{2}\right)$ iki sınıf bulunmaktadır.

1) $M_{1}$ ve $M_{2}$ sınıflarının öğrenci sayıları toplamı 82 'dir. $S_{1}$ 'in öğrenci sayısı $M_{2}$ sınıfının öğrenci sayısından 8 fazla, $S_{2}$ sınıfının öğrenci sayısı ise $M_{1}$ sınıfının öğrenci sayısından 3 eksiktir. $M_{2}$ sınıfında toplam 36 öğrenci bulunduğuna göre, $S_{1}$ ve $S_{2}$ sınıflarının öğrenci sayıları toplamı kaçtır?

2) $M_{1}$ ve $M_{2}$ sınıflarının öğrenci sayıları toplamı $82, S_{1}$ ve $S_{2}$ sınıflarının öğrenci sayıları toplamı $87^{\prime}$ dir. $S_{1}$ sınıfının öğrenci sayısı $M_{2}$ sınıfının öğrenci sayısından 8 fazla, $S_{2}$ sınıfının öğrenci sayısı ise $M_{1}$ sınıfının öğrenci sayısından 3 eksiktir. $M_{1}$ sınıfında toplam ---öğrenci bulunmaktadır. Problemde verilen durumların sağlanabilmesi için boşluğa hangi sayı ya da sayılar gelebilir?

3) $M_{1}$ ve $M_{2}$ sınıflarının öğrenci sayıları toplamı $82, S_{1}$ ve $S_{2}$ sınıflarının öğrenci sayıları toplamı 84 tür. $S_{1}$ sınıfının öğrenci sayısı $M_{2}$ sınıfının öğrenci sayısından 8 fazla, $S_{2}$ sınıfının öğrenci sayısı ise $M_{1}$ sınıfının öğrenci sayısından 3 eksiktir. $M_{1}$ sınıfında toplam --- öğrenci bulunmaktadır. Problemde verilen durumların sağlanabilmesi için boşluğa hangi sayı ya da sayılar gelebilir?

Şekil 4. Karmaşık toplamsal durum içeren gerçek yaşam problemi 
Tanışlı \& Dur - Çukurova Üniversitesi Eğitim Fakültesi Dergisi, 47(1), 2018, 60-108

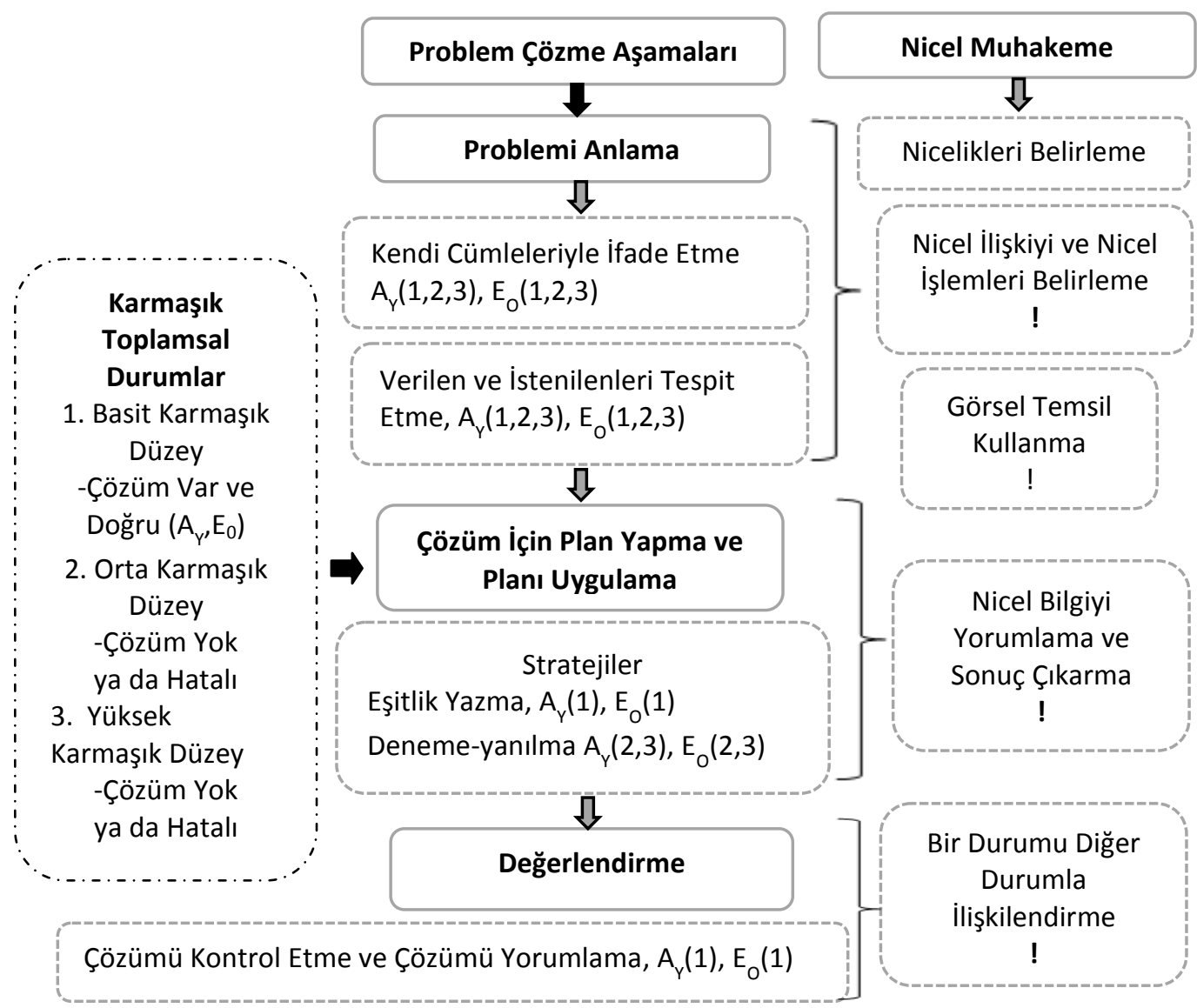

Şekil 5. Karmaşık toplamsal durumlar içeren problemi çözme sürecinde öğrencilerin çözüm süreçleri ve nicel muhakeme becerileri

Şekil 5' te görüldüğü gibi Atakan ve Emel sadece basit karmaşık düzeyde verilen problemi çözülebilmiş, orta ve yüksek karmaşık düzeydeki problemlerin çözümünde başarılı olamamışlardır. Problemlerin çözümüne başlarken Atakan ve Emel problemleri kendi cümleleriyle ifade etmiş, verilenleri ve istenenleri belirleyebilmişlerdir. Ancak bu süreçte iki öğrencide üç problemde niceliklere odaklanmadan doğrudan sayılara ve bilinmeyenlere odaklanarak çözüm için plan yapma ve planı uygulama aşamasında, birinci problemde eşitlik yazma (bilinmeyenin harf ile temsil edildiği matematiksel bir eşitlik yazma), diğer iki problemin çözümünde ise deneme yanılma stratejisini kullanmışlar, çözümlerini de cebirsel olarak gerçekleştirmişlerdir. Değerlendirme aşamasında ise sonucun doğruluğunu kontrol etmişlerdir. Güçlük derecesi artan ve nicel muhakeme gerektiren diğer iki problem durumunda ise öğrenciler "sınıflardaki toplam öğrenci sayıları" olarak nicelikleri ve "toplam sayılar arasındaki farkı" ya da "iki farklı bölümdeki iki sınıf arasındaki farkı" diğer bir değişle nicelikler arası ilişkileri yorumlayamadıkları için deneme yanılma stratejisi kullanılmış, doğru yanıta ulaşılamamışlardır.

Şekil 6'da verilen farkların kombinasyonunu içeren problemleri çözme sürecinde öğrencilerin çözüm performansları, çözüm aşamaları ve nicel muhakeme becerileri Şekil 7'de verilmiştir. 


\section{Farkların kombinasyonunu içeren gerçek yaşam problemi}

Ahmet ile Batuhan yapılacak matematik sınavında hangisinin kendi kız kardeşinden diğerine göre daha fazla net yapacağı konusunda iddiaya giriyorlar. Sınav yapıldıktan sonra Ahmet'in 12 netle iddiayı kazandığı görülüyor. Bu sınavda problem durumu gerçekleşecek şekilde boşlukları uygun sayılarla doldurunuz.

1) Ahmet:92 net, kardeşi Emine:76 net; Batuhan: 98 net; kardeşi Şule: ... net

2) Ahmet:92 net, kardeşi Emine:76 net; Batuhan: ... net; kardeşi Şule: ... net

3) Ahmet: ... net, kardeşi Emine: ... net; Batuhan: ... net; kardeşi Şule: ... net

Şekil 6. Farkların kombinasyonunu içeren gerçek yaşam problemi

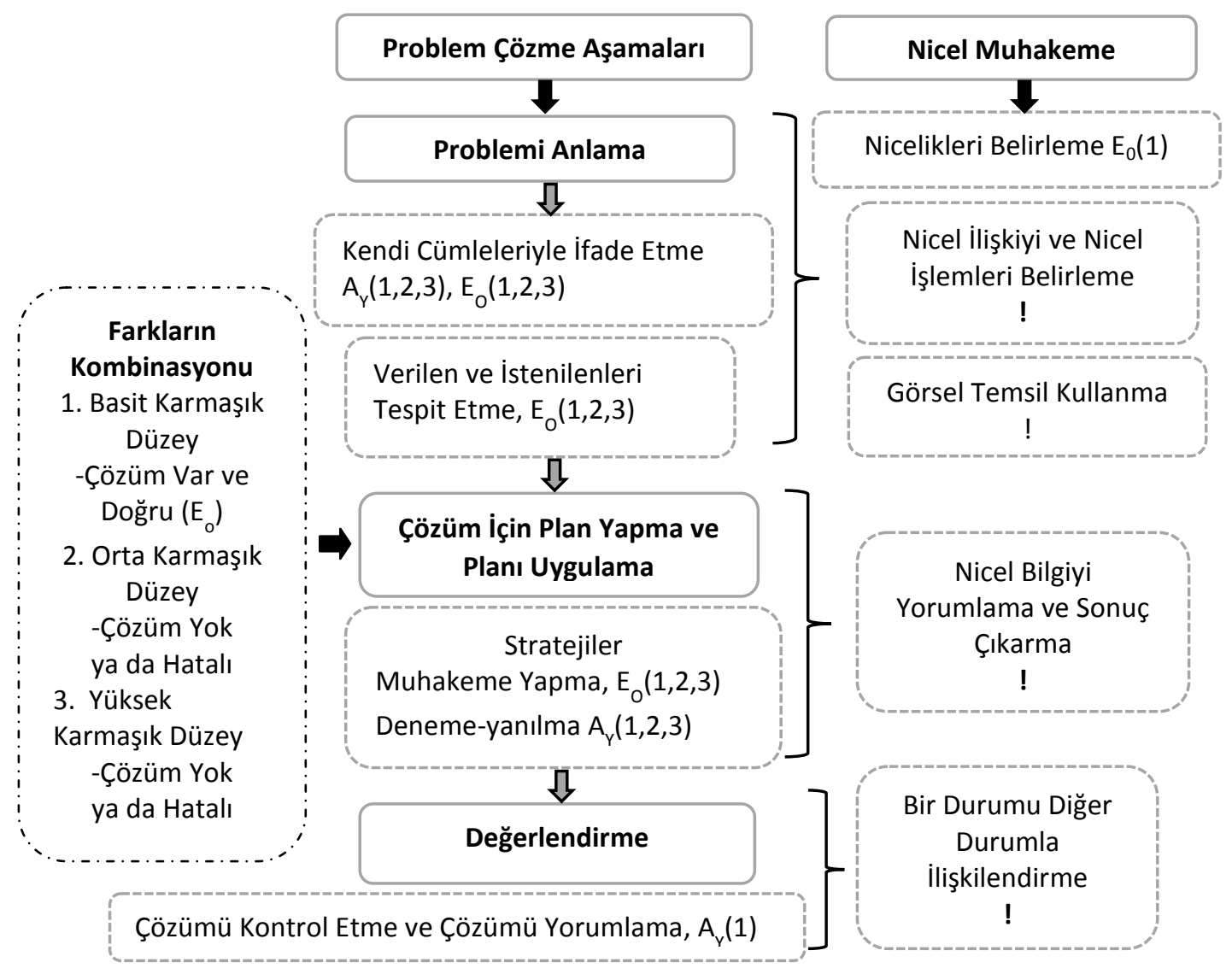

Şekil 7. Farkların kombinasyonunu içeren problemi çözme sürecinde öğrencilerin çözüm süreçleri ve nicel muhakeme becerileri

Şekil 7’ de görüldüğü gibi sadece basit karmaşık düzeyde verilen problemi Emel çözülebilmiştir. Problemlere başlarken iki öğrenci de problemi kendi cümleleriyle ifade etmiş, ancak Atakan verilenleri ve istenenleri belirleyememiş dolayısıyla problemi anlayamamıştır. Problem durumlarında öğrencilerin öncelikle yedi niceliğin (yani Ahmet'in, kardeşi Emine'nin, Batuhan'ın, kardeşi Şule'nin skorları, sonra iki nicelikten elde edilen diğer nicelikler Ahmet ve Emine'nin skorları arasındaki fark, Batuhan ve Şule'nin skorları arasındaki fark, son olarak da farkın farkı olarak oluşan yeni nicelik Ahmet'in iddiası) farkında olmaları beklenmektedir. Bu süreçte öğrencilerin nicel muhakeme bağlamında öncelikle iki farkın karşılaştırılmasını yani "kardeşler arası matematik skoru" ile "iki arkadaş arasında ortaya konulan skorun" karşılaştırılmasını ve "farkların farkı" nicel ilişkisini keşfetmeleri önemlidir. Emel birinci problem dışındaki problemlerde, Atakan ise tüm problemlerde bu durumu fark edemediği için çözümlerinde başarılı olamamışlardır. 
Tanışlı \& Dur - Çukurova Üniversitesi Eğitim Fakültesi Dergisi, 47(1), 2018, 60-108

Plan yapma ve uygulama aşamasında Emel üç problemde muhakeme yapma stratejisini (doğru olan $p$ durumundan yola çıkarak q nun elde edilmesi) kullanmış ancak sadece birinci problemde doğru sonuca ulaşmıştır. Problemde öncelikle sayılara ve işlemlere odaklanmış ve aritmetiksel bir muhakeme yaparak çözümünü "Ahmet 92 net yapmış, Emine 76 net. 92 den 76 çıkarsa 16 bulunur --- Batuhan ile Şule arasındaki net farkı 4 olursa Ahmet 12 netle kazanır" şeklinde açıklamıştır. Değerlendirme aşamasında ise sonucun doğruluğunu kontrol etmiştir. Emel aslında bu problemde niceliklerin farkındadır. Ancak nicel fark ve farkın farkı ilişkilerini tam olarak kavramsallaştırmadığı için güçlük derecesi artan diğer problemlerde zorlanmıştır. Atakan ise nicelikleri ve bu nicelikler arasındaki ilişkiyi keşfedemediğinden tüm problem durumlarında deneme yanılma stratejisini kullanmış ve çözüme ulaşamamıştır. Örneğin birinci problemde "Emine 76 yaptıysa 12 netle Şule'yi geçtiği için 76-12=64 ve Şule 64 net yapar" şeklinde anlamsız aritmetik işlemler gerçekleştirmiştir.

Şekil 8'de verilen nicel oran içeren problemlerini çözme sürecinde öğrencilerin çözüm performansları, çözüm aşamaları ve nicel muhakeme becerileri Şekil 9'da verilmiştir.

\section{Nicel oran içeren gerçek yaşam problemi}

1) Gelecekte bir zaman Ayhan 45 yaşında olacaktır. O zaman Ayhan'ın yaşı kızı Feyza'nın 3 katı olacaktır. Feyza şu anda 11 yaşında olduğuna göre Ayhan kaç yaşındadır?

2) A musluğu bir havuzu 60 dakikada, B musluğu ise aynı kapasiteye (hacme) sahip başka bir havuzu 80 dakikada doldurabilmektedir. B musluğu A musluğundan 15 dakika önce açıldığına göre kaç dakika sonra iki havuzdaki su miktarları eşit seviyede olur?

Şekil 8. Nicel oran içeren gerçek yaşam problemi

Şekil 9'da görüldüğü gibi, iki öğrenci de sadece basit karmaşık düzeyde verilen problemi çözülebilmiş, yüksek karmaşık düzeydeki problemin çözümünde başarılı olamamışlardır. Basit karmaşık düzeydeki probleme başlarken Atakan ve Emel problemi kendi cümleleriyle ifade etmişler, verilen ve istenileni belirlemişlerdir. Öğrenciler bu problem durumunda dört niceliğinde (babanın ve kızın şimdiki yaşları, babanın ve kızın gelecekteki yaşları) farkında olmuştur. Ancak iki öğrenci de zamansal ilişki, nicel fark ve nicel oran ilişkilerini tam olarak ifade etmeden doğrudan sayılara odaklanmış ve çözüme geçmişlerdir. Bu bağlamda plan yapma ve uygulama aşamasında Atakan ve Emel muhakeme yapma stratejisini kullanmışlar ve bu süreçte üç adımda aritmetik işlemler gerçekleştirmişlerdir. Çözümde önce kızın gelecekteki yaşını belirlemişler, sonra şimdiki ve gelecekteki yaşlar arasındaki farkı bulmuşlar, son olarak da bu farkı babanın yaşından çıkarmışlardır. Yani problemde kullanılacak üç sayıyı $(45,3,11)$ ve doğru aritmetik işlemi (bölme, çıkarma) seçerek doğru çözüme ulaşmışlardır. En son değerlendirme aşamasında çözümün doğruluğunu kontrol etmişlerdir. Emine'nin çözümü örnek olarak sunulmuştur. Atakan ise ayrıca "... 11' e kaç eklersem 45'in katı olur" şeklindeki muhakemesiyle bu problem durumu için ikinci bir çözüm yolu önermiştir.

İkinci probleme başlarken iki öğrencide problemi kendi cümleleriyle ifade etmiş, verilen ve istenilenleri belirlemiştir. Ancak öğrenciler problem durumunda nicelikler (A ve B musluklarının havuzu doldurma süreleri, B musluğu ile A musluğunun havuzu doldurmaya başlama zamanları ve iki havuzdaki su miktarlarının eşit olma zamanı) ve aralarındaki nicel ilişkiler (iki musluğun doldurma oranları ve süreleri) üzerine muhakeme yapamamışlardır. Diğer bir değişle havuzdaki su miktarları arasındaki farkın doldurma oranları ve süreleri farkı olan bir hızda kapanacağına ilişkin bilgiyi yorumlayamamışlardır. Dolayısıyla plan yapma ve uygulama aşamasında deneme yanılma stratejisini kullanmışlar ve anlamsız aritmetik işlemler gerçekleştirmişlerdir. Örneğin Atakan başlangıçta muslukların havuzları doldurma oranları ve süreleri arasındaki ilişkiyi hatalı yorumladığı için problemin yanıtına ulaşamamıştır. 


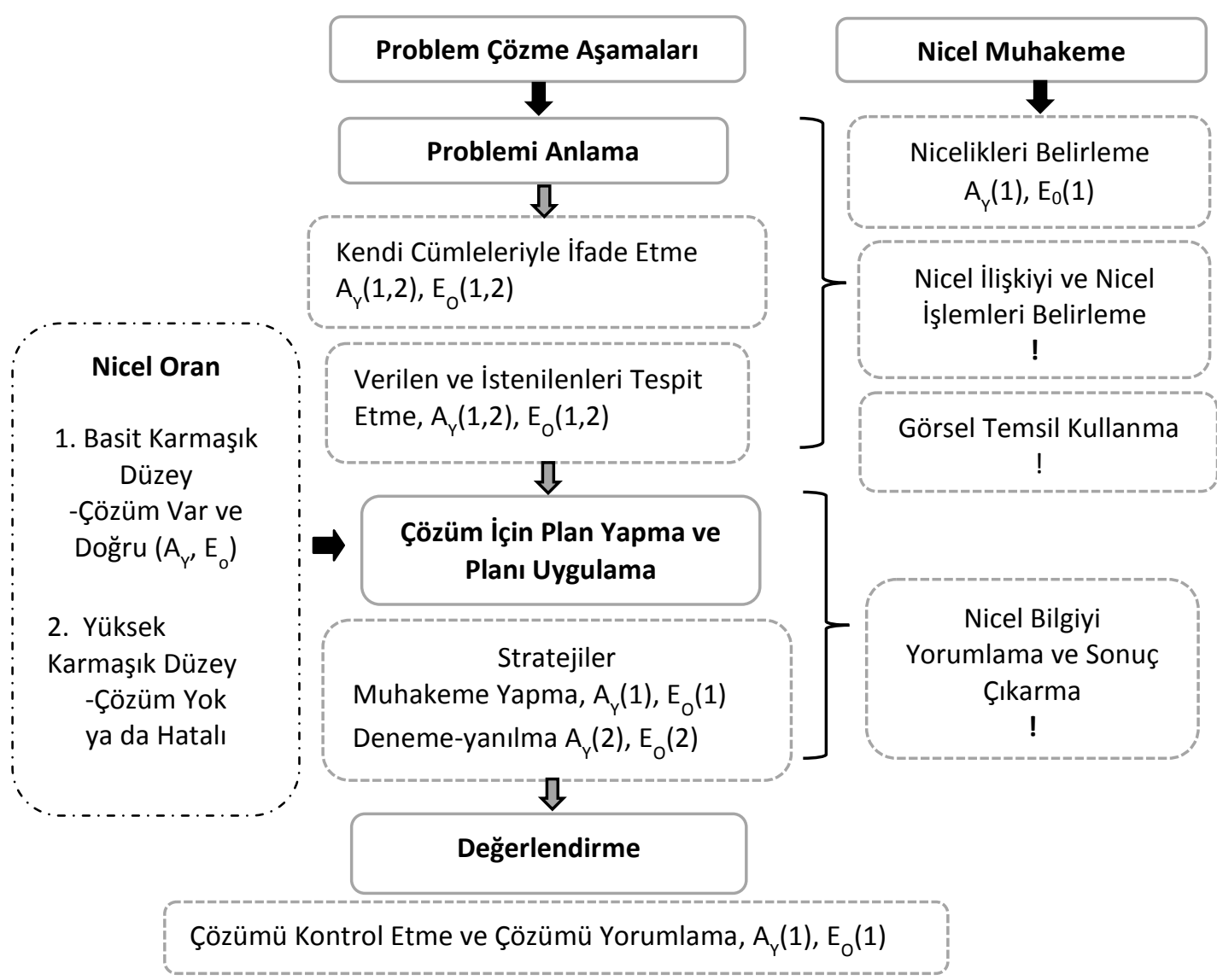

Şekil 9.Nicel oran içeren problemi çözme sürecinde öğrencilerin çözüm süreçleri ve nicel muhakeme becerileri

Tüm problem durumları dikkate alındığında öğrencilerin problemlerde nicelikler ve nicelikler arası ilişkiden ziyade daha çok sayılara ve sayısal ilişkilere odaklandıkları ve genel olarak çözümünde zorlandıkları problemlerde deneme yanılma stratejisini kullandıkları görülmüştür. Aynı zamanda genel olarak basit karmaşık düzeyde verilen problem durumlarını çözebildikleri, karmaşıklık düzeyi artıkça problemleri çözmede zorlandıkları da gözlenmiştir. Öğrenci günlükleri incelendiğinde ise, öğrencilerin genel olarak daha önce bu türde problem durumları ile karşılaşmamalarını zorlanma nedeni olarak ileri sürdükleri görülmüştür.

Öğretim Sonrası İki Öğrencinin Nicel Fark, Karmaşık Toplamsal Durumlar, Farkların Kombinasyonu ve Nicel Oran Türündeki Problemleri Çözme Süreçleri ve Nicel Muhakeme Becerileri

Nicel fark içeren şekil $10^{\prime}$ da sunulan problemleri çözme sürecinde öğrencilerin çözüm performansları, çözüm aşamaları ve nicel muhakeme becerileri Şekil 11'de verilmiştir. 
Tanışlı \& Dur - Çukurova Üniversitesi Eğitim Fakültesi Dergisi, 47(1), 2018, 60-108

\section{Nicel fark içeren gerçek yaşam problemi}

Erkan, Alper ve Necati üç arkadaştır ve birbirleriyle sık sık telefonda görüşmektedir. İçlerinden birisinin kontörünün azalması durumunda diğer iki arkadaş o kişiye kontör göndermektedir. Üç arkadaşın belli bir süre içerisinde birbirlerinden aldıkları kontör miktarı şu şekildedir:

(Not: Erkan, Alper ve Necati bu süre zarfı içerisinde başka hiçbir yerden kontör almamaktadır ve hiç kontör harcamamaktadır.

1) Erkan'a, Alper'den 12, Necati'den 18; Alper'e, Erkan'dan 24, Necati'den 16; Necati'ye, Alper'den 5, Erkan'dan 8 kontör gelmiştir. Verilen bu bilgilere göre Alper'in başlangıçtaki kontör miktarı ile son durumdaki kontör miktarını kıyaslayınız.

2) Erkan'a, Alper'den 16, Necati'den 8; Alper'e, Erkan'dan --- Necati' den 6; Necati'ye, Alper'den 15, Erkan'dan 46 kontör gelmiştir. Bu durumlar sonunda Alper ilk durumuna göre 8 fazla kontöre sahip oluyor. Buna göre Alper'e Erkan'dan kaç kontör gelmiştir?

3) Erkan'a, Alper'den ---, Necati'den ---; Alper'e, Erkan'dan ---, Necati'den ---; Necati'ye, Alper'den ---, Erkan'dan ---, kontör gelmiştir. Yukarıdaki kontör gönderme işlemlerinin tamamlanması durumunda Alper'in ilk durumuna göre 4 eksik kontörü kalacak şekilde boşlukları doldurunuz.

Şekil 10.Nicel fark içeren gerçek yaşam problemi

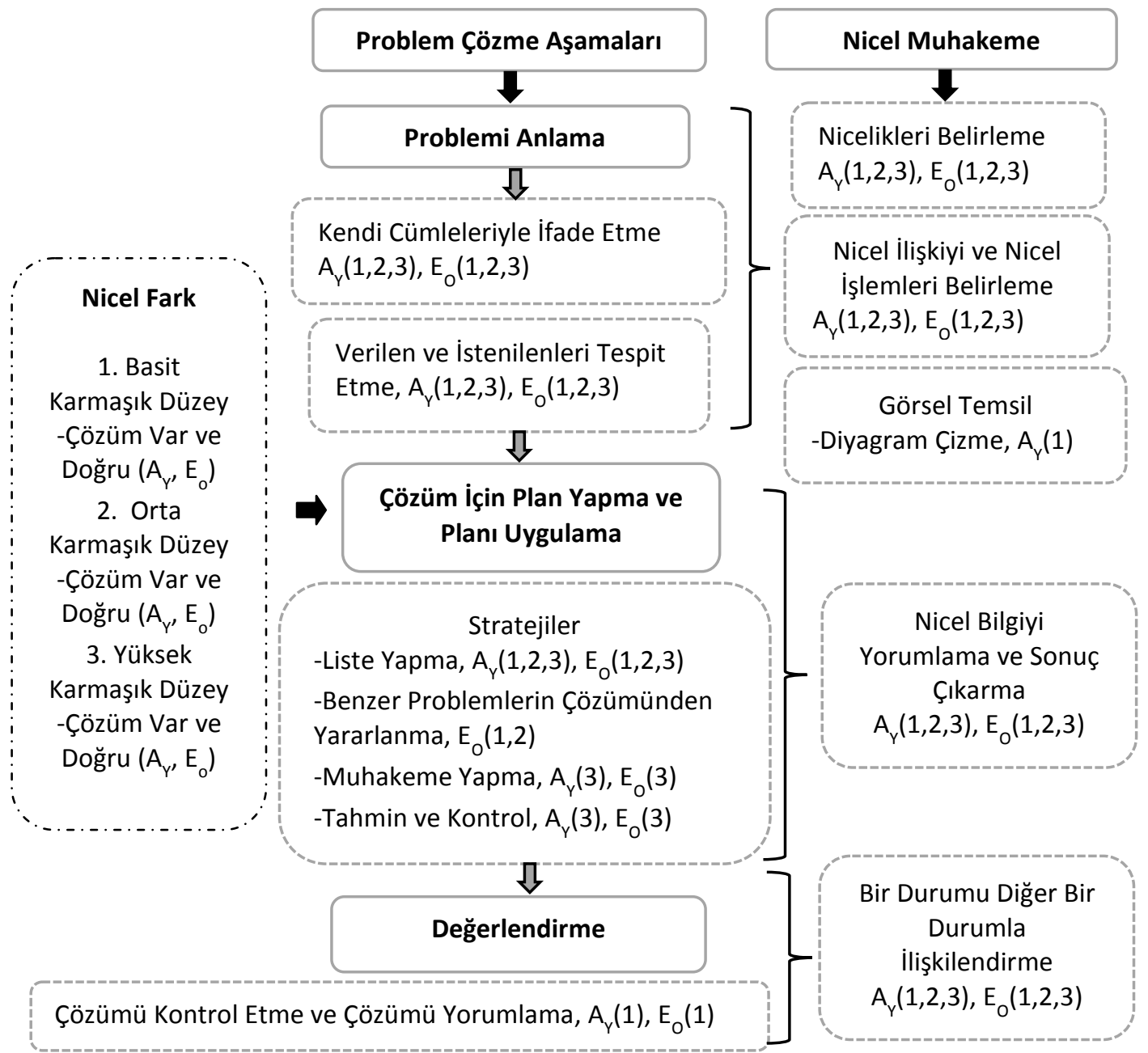

Şekil 11. Nicel fark içeren problemi çözme sürecinde öğrencilerin çözüm süreçleri ve nicel muhakeme beceriler 
Tanışlı \& Dur - Çukurova Üniversitesi Eğitim Fakültesi Dergisi, 47(1), 2018, 60-108

Şekil 11'de görüldüğü gibi, nicel fark içeren problemlerin çözümüne başlarken Atakan ve Emel üç problemi de çözülebilmişlerdir. Atakan ve Emel problemleri kendi cümleleriyle ifade ederek, verilen ve istenilenleri belirlemişlerdir. Bu süreçte ise problemde "gönderilen kontör" ve "gelen kontör " olarak niceliklerin farkında olmuş ve bu niceliklerin değerlerini gelen kontörler için artı, gönderilen kontörler için eksi işaretleri ile temsil etmişlerdir. Ayrıca "gönderilen ve gelen kontörler arasındaki toplamsal farka" ve "başlangıçta ve sonda kontör miktarlarının nasıl değiştiğine" ilişkin nicel ilişkiyi de belirlemişlerdir. Bu aşamada Atakan belirlediği nicel ilişkileri diyagram çizerek göstermiştir.

Nicelikler ve nicelikler arası ilişkinin kavramsallaştırılması iki öğrencinin çözüm süreçlerine de yansımış ve plan yapma ve uygulama aşamasında liste yapma, benzer problemlerin çözümünden yararlanma (daha basit benzer bir problemle ilişkilendirerek çözme), muhakeme yapma ile tahmin ve kontrol (problemin yanıtı ile ilgili tahmin yürütme ve yapılan tahminin yanıt olup olmadığına bakma) stratejilerini kullanmışlardır. Liste yapma stratejisi üç problemde de Atakan ve Emel tarafından doğru kullanılmış ve nicel yöntemle doğru çözüme ulaşılmıştır. Değerlendirme aşamasında ise sonucun doğruluğu kontrol edilmiş ve yorumlanmıştır. Emel'in çözümü aşağıda örnek olarak sunulmuştur.

Bu çözümünü Emel “Önce ben zararı buldum. 16+15=31 zarar, 6 kar. 31-6=25 zarar. Önce 25’i kapatacak sonra da 8 fazlaya geçmesi için 25+8=33 alması lazım" şeklinde keşfettiği nicel bilgiyi yorumlayarak sonuca ulaşmıştır. Görüldüğü gibi Emel, problemin çözümünde Atakan da benzer şekilde kar zarar problemlerin çözümünden yararlanmıştır. Atakan ise problemin başında çizdiği diyagram üzerinden aşağıda Şekil 12'de verildiği gibi problemi çözmüştür.

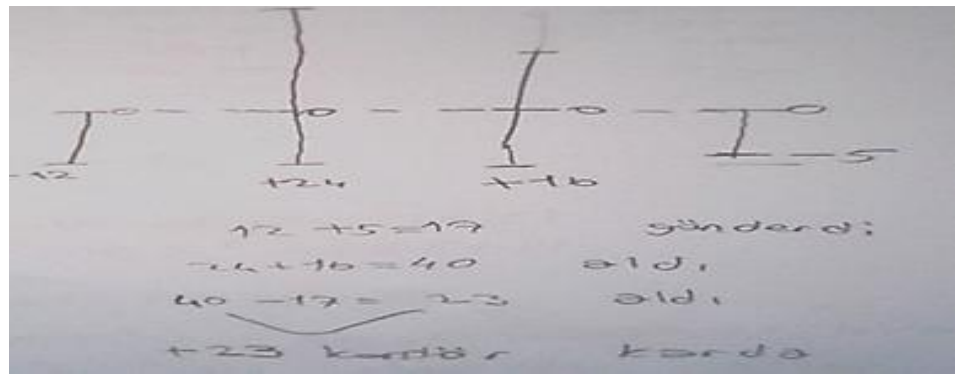

Şekil 12. Atakan'ın çözümü

Atakan ayrıca “Necati ve Erkan'ın bir önemi yok. O yüzden sadece Alper’i çizdim. İlk çözümümde diğer kişileri yazamayabilirdim. Önemli olan kişi Alper'dir. Necati ve Erkan'ın sadece Alper'e gönderdikleri ve Alper'den kontör aldıkları durumlar önemlidir. Necati ve Alper'in birbirlerine gönderdikleri ve birbirlerinden aldıkları kontörlerin önemi yoktur" şeklinde nicel bilgiyi yorumlayıp buna göre bir sonuca ulaşmıştır. Değerlendirme aşamasında ise öğrenciler problemin başında nicelikleri, nicel ilişkileri ve işlemleri belirledikleri için sırasıyla problem durumlarını birbiriyle ilişkilendirerek sonuca ulaşmışlardır.

Şekil 11'de görüldüğü gibi, ikinci ve üçüncü problemlerin çözümünde ise Atakan ve Emel muhakeme yapma ile tahmin ve kontrol stratejilerini kullanılmışlardır. Örneğin üçüncü problemin çözümünde Atakan;

$A_{Y}$ : Erkan ve Necati'nin birbirlerine gönderdikleri kontör miktarları bizi ilgilendirmiyor. Onların birbirlerine gönderdikleri kontörlere istediğimiz sayıları yazabiliriz. Alper'in ilk 3 durumunu yazarım sonra da son durumu istenilene göre bulurum. Sağlamasını da yapınca doğru çıktı.

Ar: Peki buradaki boşluklara hangi sayılar gelebilir?

$\mathbf{A}_{Y}$ : Boşluklara bir sürü sayı gelebilir. Yeter ki Alper ilk duruma göre 4 zararda olsun. Mesela; Alper 100 vermiştir 96 almıştır 4 zararda olur ya da 2000 vermiştir 1996 almıştır 4 zararda olur.

Ar: Boşluklara gelebilen sayılar arasında nasıl bir ilişki vardır?

$\mathbf{A}_{\mathbf{Y}}$ : Alper'in 4 kontör zararda olması şartıyla her sayı gelir. 
Tanışlı \& Dur - Çukurova Üniversitesi Eğitim Fakültesi Dergisi, 47(1), 2018, 60-108

şeklinde bir açıklamada bulunmuştur. Diyalogdan da görüldüğü gibi, öğrencinin problemde Alper'in durumuna odaklandığı ve nicel muhakeme ile (Alper'in ilk durumu ile son durumu arasındaki ilişkiyi) nicel ilişkiyi keşfettiği söylenebilir. Aynı zamanda keşfettiği nicel bilgiyi tahmin ve kontrol stratejisi ile yorumladığı ve bir sonuca (4 eksik olacak şekilde boşluklara her sayı gelebileceği) ulaştığı da görülmektedir. Değerlendirme aşamasında ise iki öğrenci de sonuçlarının doğruluğunu test etmişlerdir.

Şekil 13'te verilen karmaşık toplamsal durum içeren problemleri çözme sürecinde öğrencilerin çözüm performansları, çözüm aşamaları ve nicel muhakeme becerileri Şekil 14'de verilmiştir.

\section{Karmaşık toplamsal durum içeren gerçek yaşam problemi}

iki grup arasında yapılan bir bilgi yarışmasında Emine ile Gülşen birinci grupta ve rakipleri olan Hakan ile Ahmet ise ikinci grupta yer almaktadır. 100 soru üzerinden yapılan bu bilgi yarışmasına ilişkin bilgiler aşağıda verilmiştir.

1) Hakan ile Ahmet'in doğru cevap verdikleri toplam soru sayısı 94 tür. Emine'nin verdiği doğru cevap sayısı, Ahmet'in verdiği doğru cevap sayısından 2 eksik, Gülşen'in verdiği doğru cevap sayısı ise Hakan'ın verdiği doğru cevap sayısından 6 fazladır. Ahmet'in doğru cevap verdiği soru sayısı 42 olduğuna göre, Emine ve Gülşen'in doğru cevap verdikleri toplam soru sayısı kaçtır? Yarışmayı hangi grup kazanmıştır?

2) Hakan ile Ahmet'in doğru cevap verdikleri toplam soru sayısı 94 tür. Emine ile Gülşen'in doğru cevap verdikleri toplam soru sayısı 98'dir. Emine'nin verdiği doğru cevap sayısı, Ahmet'in verdiği doğru cevap sayısından 2 eksik; Gülşen'in verdiği doğru cevap sayısı ise Hakan'ın verdiği doğru cevap sayısından 6 fazladır. Gülşen'in doğru cevap verdiği soru sayısı -$\therefore$ dır. Problemde verilen durumların sağlanabilmesi için boşluğa hangi sayı ya da sayılar gelebilir?

3) Hakan ile Ahmet'in doğru cevap verdikleri toplam soru sayısı 94 tür. Emine ile Gülşen'in doğru cevap verdikleri toplam soru sayısı 96'dır. Emine'nin verdiği doğru cevap sayısı, Ahmet'in verdiği doğru cevap sayısından 2 eksik; Gülşen'in verdiği doğru cevap sayısı ise Hakan'ın verdiği doğru cevap sayısından 6 fazladır. Gülşen'in doğru cevap verdiği soru sayısı -$\therefore$ dır. Problemde verilen durumların sağlanabilmesi için boşluğa hangi sayı ya da sayılar gelebilir?

Şekil 13. Karmaşık toplamsal durum içeren gerçek yaşam problemi

Şekil 14'te görüldüğü gibi, Atakan ve Emelüç problemi de çözülebilmişlerdir. Problemlerin çözümüne başlarken Atakan ve Emel problemleri kendi cümleleriyle ifade etmiş, verilenleri ve istenenleri belirlemişlerdir. Bu süreçte öğrencilerden “Ahmet ve Hakan ile Emine ve Gülşen'in toplam doğru cevap sayıları", "Emine ve Ahmet ile Gülşen ve Hakan'ın doğru cevap sayıları arasındaki fark" olarak niceliklerin farkında olmaları beklenmektedir. Aynı zamanda bu nicelikler arasındaki nicel ilişkiyi yani "Ahmet ile Hakan ve Emine ile Gülşen'in toplam doğru yanıt sayıları arasındaki farkı" belirleyebilmeleri de önemlidir. Bu bağlamda Atakan tüm sorularda bu durumu göstermiş, Emel ise basit karmaşık düzeydeki problemde ön klinik görüşmede yaptığı gibi, öncelikle sayılara ve bilinmeyenlere odaklanmış eşitlik yazma stratejisini kullanarak çözümü gerçekleştirmiştir. Ancak güçlük derecesi artan ikinci ve üçüncü problemlerde nicel işlemlere yönelmiştir.

Problemi anlama aşamasında ayrıca Atakan tüm problemlerde, Emel ise ikinci ve üçüncü problemlerde belirledikleri nicelikler ve aralarındaki ilişkileri diyagram çizerek göstermişlerdir. Plan yapma ve planı uygulama aşamasında öğrenciler muhakeme yapma ile tahmin ve kontrol stratejilerini ve Emel ayrıca yukarıda bahsedildiği gibi birinci problemde eşitlik yazma stratejisini kullanmıştır. 
Tanışlı \& Dur - Çukurova Üniversitesi Eğitim Fakültesi Dergisi, 47(1), 2018, 60-108

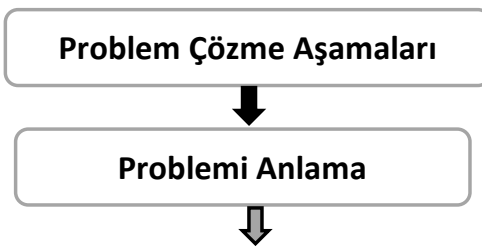

Kendi Cümleleriyle ifade Etme

$A_{Y}(1,2,3), E_{O}(1,2,3)$

Toplamsal

Durumlar

1. Basit Karmaşık Düzey -Çözüm Var ve Doğru $\left(A_{Y}, E_{0}\right)$

2. Orta Karmaşık Düzey -Çözüm Var ve Doğru $\left(A_{Y}, E_{0}\right)$

3. Yüksek Karmaşık Düzey -Çözüm Var ve Doğru $\left(A_{\gamma}, E_{0}\right)$
Verilen ve İstenilenleri Tespit

Etme, $A_{Y}(1,2,3), E_{O}(1,2,3)$
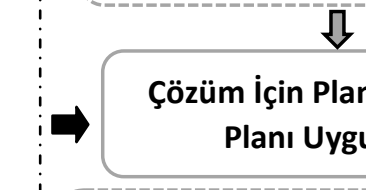

Çözüm İçin Plan Yapma ve Planı Uygulama

\section{Stratejiler}

-Eşitlik Yazma, $E_{0}(1)$

-Muhakeme Yapma, $A_{\gamma}(1,2,3), E_{o}(2,3)$

-Tahmin ve Kontrol, $A_{\gamma}(2,3), E_{0}(2,3)$
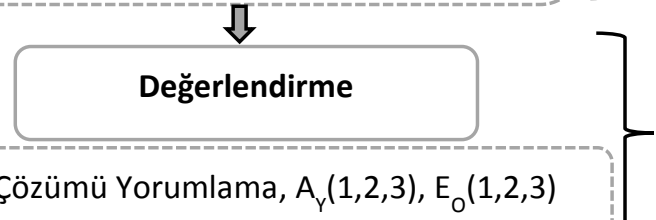

Nicel Muhakeme

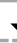

Nicelikleri Belirleme

$A_{Y}(1,2,3), E_{0}(2,3)$

Nicel ilişkiyi ve Nicel

İşlemleri Belirleme

$A_{Y}(1,2,3), E_{0}(2,3)$

Görsel Temsil

-Diyagram Çizme,

$A_{Y}(1,2,3), E_{O}(2,3)$

Nicel Bilgiyi

Yorumlama ve Sonuç Çıkarma

$A_{Y}(1,2,3), E_{0}(1,2,3)$

Bir Durumu Diğer Bir

Durumla

ilişkilendirme

$A_{\gamma}(1,2,3), E_{0}(1,2,3)$

Şekil 14. Karmaşık toplamsal durumlar içeren problemi çözme sürecinde öğrencilerin çözüm süreçleri ve nicel muhakeme becerileri

Emel'in problemi anlama aşamasında çizmiş olduğu diyagram üzerinden ikinci problemin çözümü ve açıklamaları Şekil 15'te sunulmuştur.

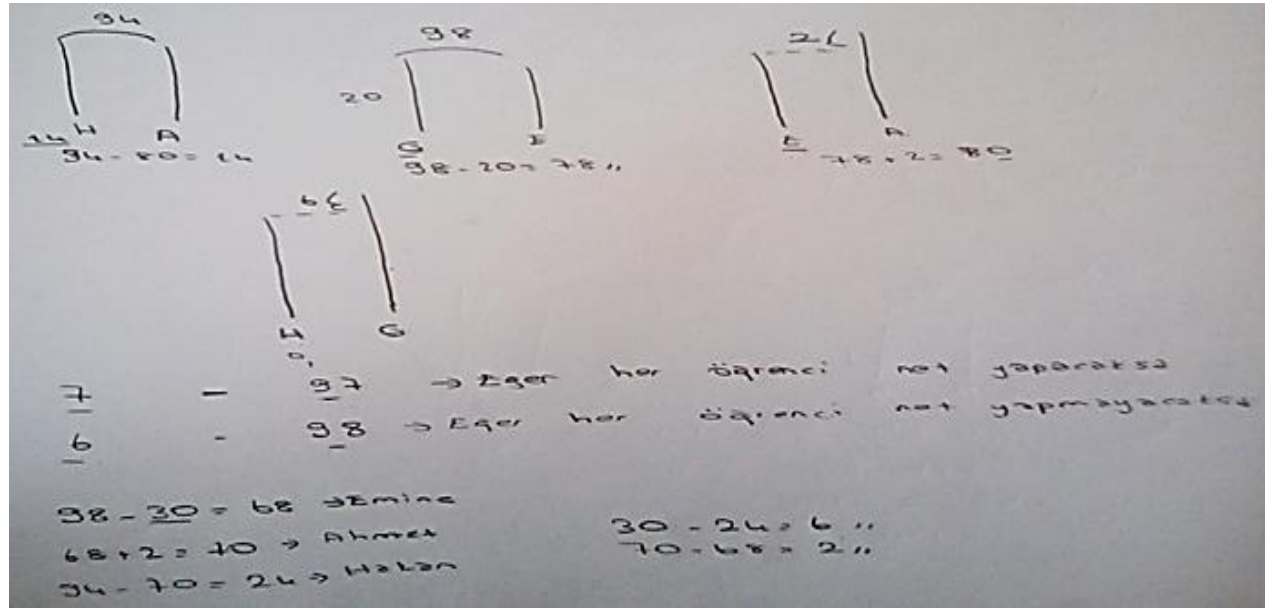

Şekil 15. Emel'in çözümü 
$\mathbf{E}_{\mathrm{o}}$ : Eğer her öğrenci en az 1 net yapacaksa Gülşen en az 7 olur, Hakan'a 1 kalması için. En yüksekte; Emine'ye 1 kalması için 97 olur. Her öğrenci 1 net yapacak diye bir kaide yoksa Gülşen'in doğru sayısı 6 ile 98 arasında olur. Çünkü Gülşen Hakan'dan 6 fazla yoksa Hakan eksi olur. Emine ve Gülşen'in doğru sayıları toplamı 98. Gülşen 98 yaparsa Emine en az 0 olur yoksa Emine eksiye düşer.

Şekil 15'ten ve diyalogdan anlaşılacağı gibi, Emel'in nicelikleri belirlediği, nicel ilişkiyi keşfettiği (toplam doğru yanıt sayıları arasındaki toplamsal fark) ve elde ettiği nicel bilgileri yorumlayarak ikinci problemde en az ve en çok verilebilecek doğru yanıt sayısı için tahmin ve kontrol stratejisi ile bir aralık belirleyebildiği görülmektedir. Üçüncü problem durumunun çözümünde ise Atakan çizdiği diyagram üzerinden,

$\mathbf{A}_{\mathbf{Y}}$ : Şimdi şöyle bir şey var (Çubukları işaret ederek) Hakan burada 6 kaybetmiş Ahmet ise +2 ile yenmiş. Hakan ile Ahmet'in zararları 4 olduğu için 98 ile 94 arası 4 olmalı. 96-94=2 olduğu için sağlamaz.

şeklinde açıklamada bulunmuştur. Atakan'da benzer şekilde nicelikler ve nicelikler arası ilişkileri belirlemiş ve açıklamalarında da görüldüğü gibi, nicel bilgiyi verilen toplam doğru yanıt sayıları (94 ile 96) arasındaki fark ile toplamsal farkın $(-2+6=4)$ eşit olmadığını ifade ederek doğru yanıt sayısının bulunamayacağı muhakemesini yaparak yorumlayabilmiştir. Öte yandan öğrencinin aynı zamanda verilere dayalı tahmin yaptığı ve tahminini test ettiği de dikkati çekmektedir. Değerlendirme aşamasında ise iki öğrenci de buldukları sonuçların doğruluklarını kontrol etmişlerdir. Bu süreçte birbiriyle ilişkili olan ve güçlük dereceleri artan üç problem durumunu da birbiriyle ilişkilendirebilmişlerdir.

Şekil 16'da verilen farkların kombinasyonunu içeren problemleri çözme sürecinde öğrencilerin çözüm performansları, çözüm aşamaları ve nicel muhakeme becerileri Şekil 17'de verilmiştir.

Farkların kombinasyonunu içeren gerçek yaşam problemi

Nisa ve Elif'in sırasıyla Alparslan ve Fatih isimli iki kardeşi vardır. Bir gün Nisa ve Elif bir yarışma düzenlerler ve bu yarışmada kim diğerine göre kendi erkek kardeşinden daha fazla sayıda düşürmeden dizinde top sektirirse o kişi galip gelecektir. Yapılan yarışma sonucunda Nisa'nın 8 farkla yarışmayı kaybettiği görülür.

1) Bu yarışmada düşürmeden dizinde; Nisa: 32 kez, Elif: 26 kez, Alparslan: 19 kez top sektirebildiğine göre, Fatih'in kaç kez top sektirebildiğini bulunuz.

2) Bu yarışmada düşürmeden dizinde, Nisa: 32 kez, Alparslan: 19 kez, Elif: --- kez, Fatih: --kez top sektirebilmiştir. İstenen şart sağlanacak şekilde boşlukları uygun sayılarla doldurunuz.

3) Bu yarışmada düşürmeden dizinde, Nisa: --- kez, Alparslan: --- kez, Elif: --- kez, Fatih: --kez top sektirebilmiştir. İstenen şart sağlanacak şekilde boşlukları uygun sayılarla doldurunuz.

Şekil 16. Farkların kombinasyonunu içeren gerçek yaşam problemi

Şekil 17'de görüldüğü gibi, Atakan ve Emelüçproblemi de çözebilmişlerdir. Problemlerin çözümüne başlarken iki öğrenci de problemleri kendi cümleleriyle ifade etmiş, verilenleri ve istenenleri belirlemişlerdir. Problem durumlarında öğrencilerin öncelikle yedi niceliğin (yani Nisa'nın ve kardeşi Alparslan'ın, Elif'in ve kardeşi Fatih'in skorları, sonra iki nicelikten elde edilen diğer nicelikler Nisa ve Alparslan'ın skorları arasındaki fark, Elif ve kardeşi Fatih'in skorları arasındaki fark, son olarak da farkın farkı olarak oluşan yeni nicelik Nisa'nın iddiası) farkında olmaları beklenmektedir. Bu süreçte öğrencilerin nicel muhakeme bağlamında öncelikle iki farkın karşılaştırılmasını yani "kardeşler arası top sektirme skoru" ile "iki arkadaş arasında ortaya konulan skorun" karşılaştırılmasını ve "farkların farkı" nicel ilişkisini keşfetmeleri önemlidir. Emel ve Atakan ise tüm problemlerde bu durumu fark etmiş ve keşfettikleri ilişkileri de diyagram çizerek göstermişlerdir. 


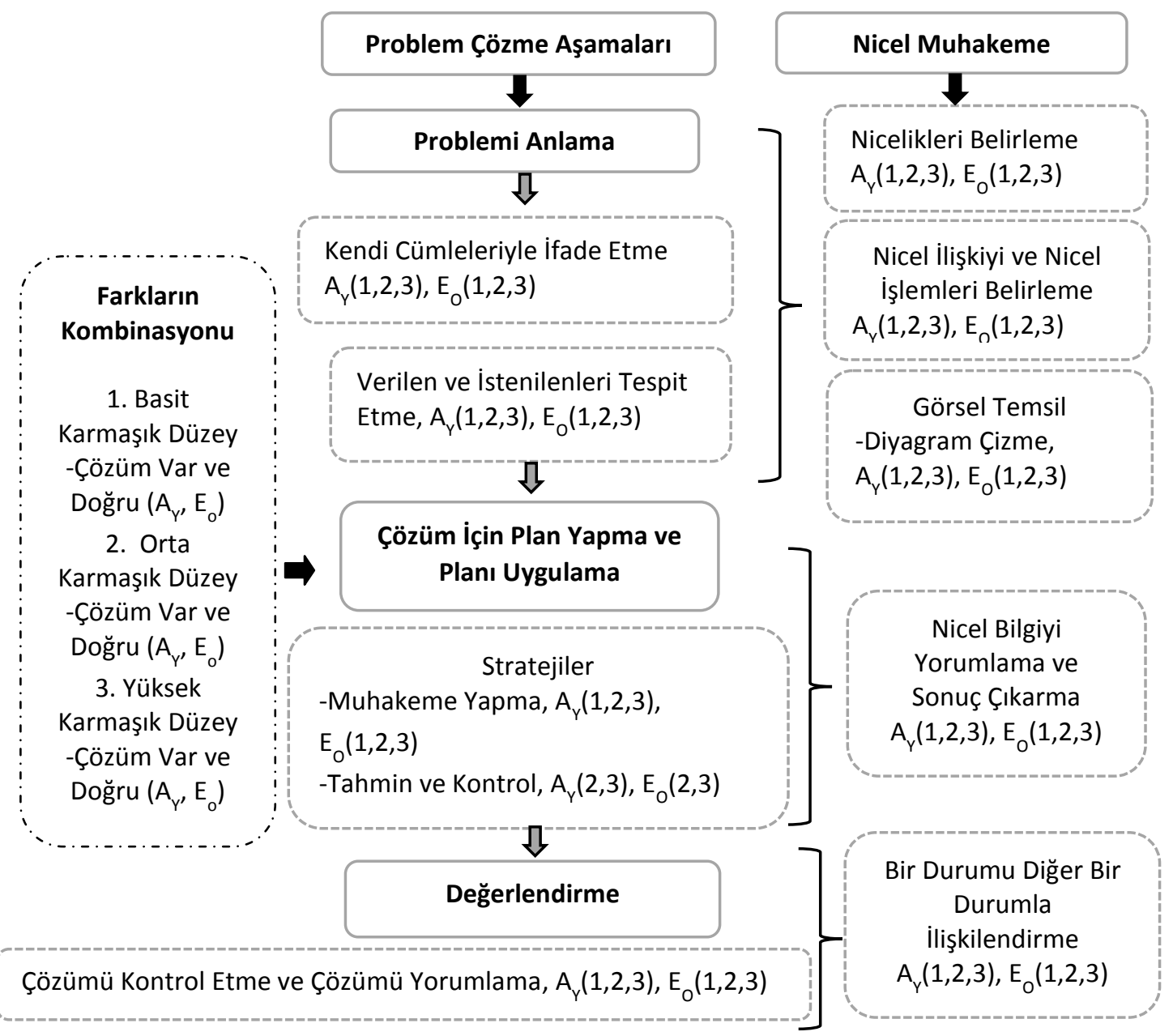

Şekil 17. Farkların kombinasyonunu içeren problemi çözme sürecinde öğrencilerin çözüm süreçleri ve nicel muhakeme becerileri

Plan yapma ve planı uygulama sürecinde Atakan ve Emel muhakeme yapma ile tahmin ve kontrol stratejisini kullanmıştır. Problemi anlama aşamasında çizmiş olduğu diyagram üzerinden Emel muhakeme yapma stratejisini kullanarak birinci problemi Şekil 18'deki gibi çözmüştür.

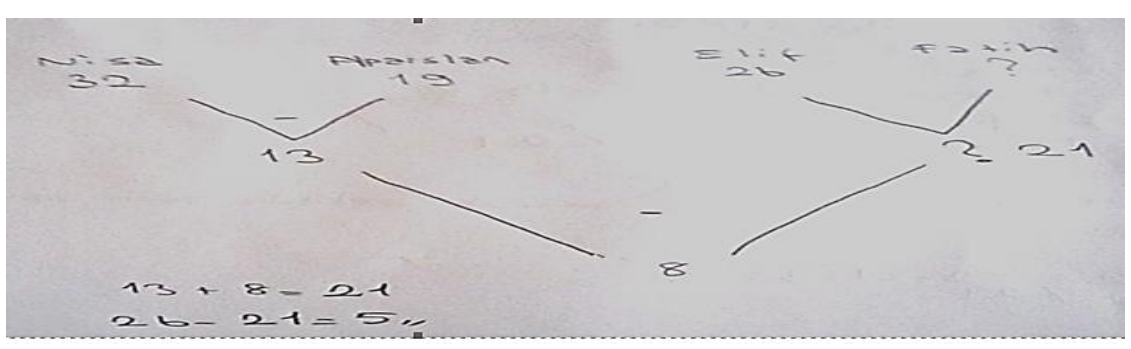

Şekil 18. Emel'in Çözümü

Şekilde $18^{\prime}$ de görüldüğü gibi, Emel kardeşlerin top sektirme sayıları arasındaki farkların farkından yani iki nicelikten elde edilen yeni nicelikler ve bunların farkından yola çıkarak nicel işlemle Fatih'in kaç kez top sektirdiğini bulmuştur. 
Aynı problemi Atakan'da çizdiği diyagram üzerinden muhakeme yapma stratejisini kullanılarak Şekil 19 'daki gibi çözmüştür.

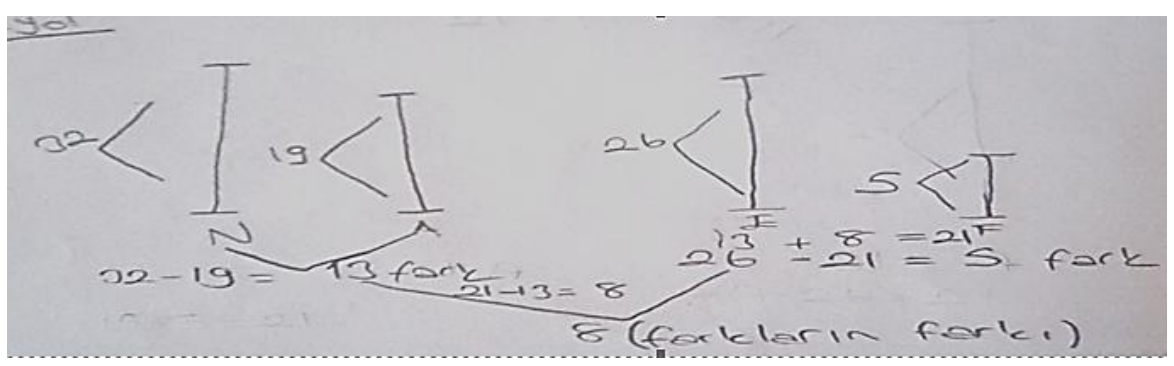

Şekil 19. Atakan'ın çözümü

İkinci ve üçüncü problem durumlarında ise muhakeme yapma ile tahmin ve kontrol stratejisi kullanılmıştır. Örneğin Emel üçüncü probleminin çözümünü,

$E_{0}$ : Nisa'ya 29 Alparslan'a 17 verdim. Aradaki fark 12. Elif yarışmayı 8 farkla kazandığı için önce 12 farkı kapatmalı sonra 8 farkla da kazanmalı. Elif'e 34 Fatih'e 14 verdim.

$\mathbf{A}_{\mathrm{R}}$ : Boşluklara başka sayılar da gelebilir mi?

$E_{0}$ : Gelir. Bu sefer Nisa 42 olsun.

$A_{R}$ : Elif ve Nisa'nın doğru sayıları eşit olabilir mi?

$\mathbf{E}_{\mathrm{o}}$ : Olur. Çünkü burada en çok yapan diye değil kardeşine en çok fark atan kimdir diye soruyor. Benim yaptığımda Alparslan'ın yaptıkları fazla, Fatih'in ki de biraz az olmalı ki Elif kazanabilsin.

$\mathbf{A}_{R}$ : Boşluklara gelebilen sayılar arasında bir ilişki var mıdır?

$\mathbf{E}_{\mathrm{o}}$ : Elif'in kardeşine attığı farkın Nisa'nın kardeşine attığı farktan 8 fazla olması ve Nisa ile Alparslan kardeşlerin Elif ve Fatih kardeşlerine attığı farkın 8 eksik olma şartıyla tüm sayılar gelebilir.

şeklinde açıklamıştır.

Benzer şekilde ikinci problemde Atakan kardeşlerin top sektirme sayıları arasındaki farkların farkından yararlanarak ve iki kardeşin top sektirme sayıları arasındaki 21 sabit farkı göz önüne alarak Elif ve Fatih'in top sektirme sayılarına ilişkin “Elif'in ve Fatih'in aralarındaki fark 21 olarak sağlayan her sayı gelebilir" gibi bir yorumda bulunmuştur. Tüm bu süreçlerde iki öğrenci de nicelikler ve nicelikler arasındaki ilişkiyi kavramsallaştırmış ve nicel bilgileri yorumlayabilmiştir. Değerlendirme aşamasında ise iki öğrencide sonuçların doğruluğunu gösterebilmiş ve üç problem durumunu birbirleriyle ilişkilendirmişlerdir.

Şekil 20'de verilen nicel oran içeren problemleri çözme sürecinde öğrencilerin çözüm performansları, çözüm aşamaları ve nicel muhakeme becerileri Şekil 21'de verilmiştir.

Nicel oran içeren gerçek yaşam problemi

1) A ve B bidonlarında başlangıçta birbirlerinden farklı miktarlarda su vardır. Bu bidonları tamamen doldurmak için eşit su akıtma kapasitesine sahip birer tane musluk açılıyor. Bidon ve musluklarla ilgili olarak şu bilgiler veriliyor. Bir süre sonra $\mathrm{A}$ bidonundaki su miktarı 36 litredir. Bu durumda A bidonundaki su miktarı B bidonundaki su miktarının 4 katıdır. B bidonunda şu anda 3 litre su bulunduğuna göre A bidonunda kaç litre su vardır?

2) Veysel bir apartmandaki bir daireyi tek başına 12 günde, Hürriyet ise bu apartmandaki (aynı biçim ve ölçülerdeki) başka bir daireyi tek başına 15 günde boyayabilmektedir. Hürriyet; Veysel'den 2 gün önce kendi dairesini boyamaya başladığına göre kaç gün sonra ikisinin de dairelerinin boyanmış bölümleri eşit ölçüde olur?

Şekil 20. Nicel oran içeren gerçek yaşam problemi 


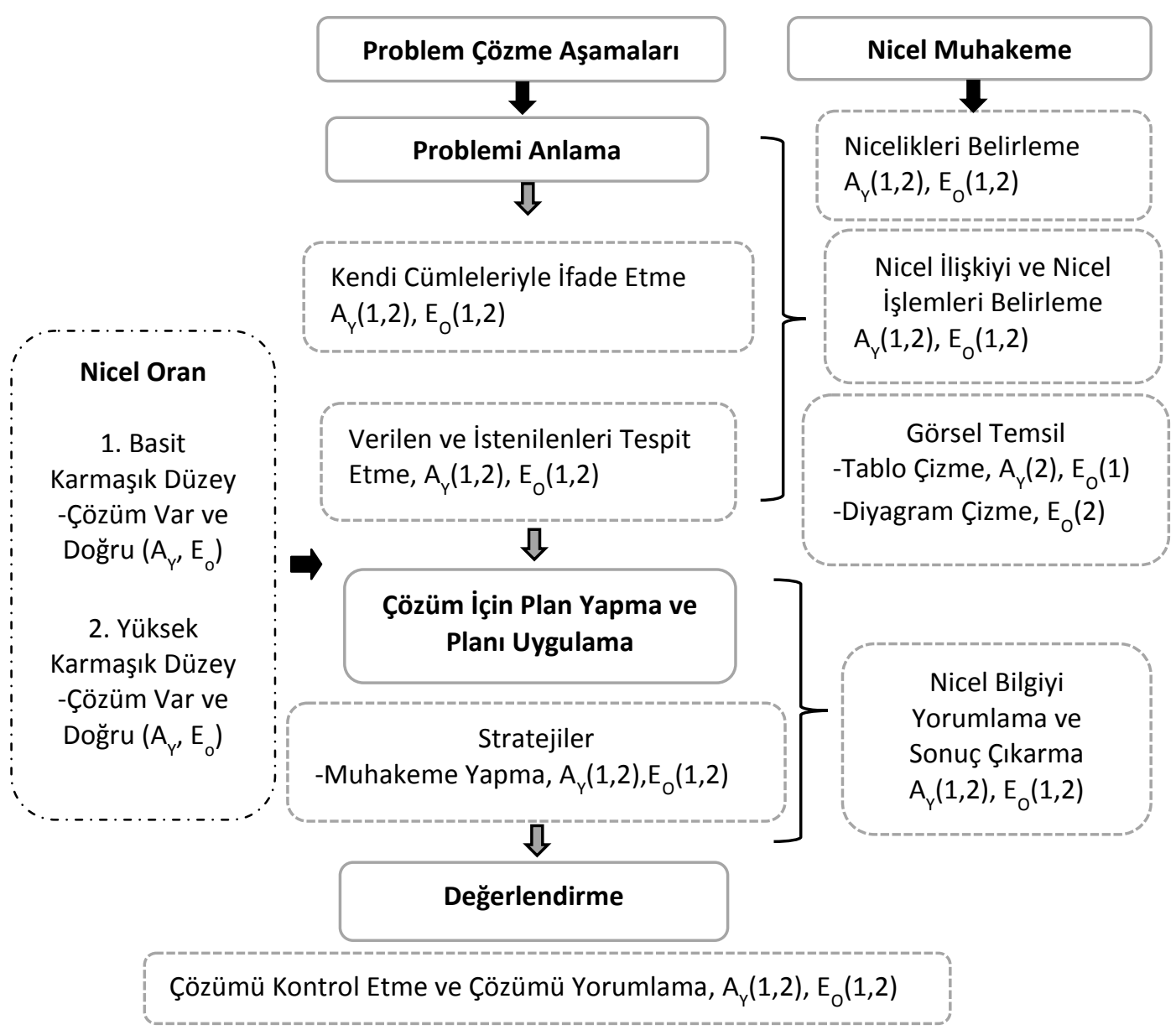

Şekil 21. Nicel oran içeren problemi çözme sürecinde öğrencilerin çözüm süreçleri ve nicel muhakeme becerileri

Şekil 21'de görüldüğü gibi, Atakan ve Emeliki problemi de başarıyla çözmüşlerdir. Problemlere başlarken Atakan ve Emel problemi kendi cümleleriyle ifade etmişler, verilen ve istenileni belirlemişlerdir. Birinci problemde öğrenciler dört niceliğinde (A ve $B$ bidonunda şimdiki mevcut su miktarı ile A ve B bidonunda bir zaman sonraki su miktarı) farkında olmuştur. Aynı zamanda "gelecekte bir noktada A bidonundaki su miktarının B bidonundaki su miktarıın dört katı olacağı" şeklindeki çarpımsal ilişkiyi (nicel oran) ve "Gelecekte ve şimdiki zamanda B bidonundaki su miktarları arasındaki fark ile gelecekte ve şimdiki zamanda A bidonundaki su miktarları arasındaki farka eşit olması" şeklindeki toplamsal ilişkiyi (nicel fark) keşfetmişlerdir. Bu süreçte Emel nicelikleri ve nicelikler arasındaki ilişkileri tablo üzerinde göstermiştir.

Plan yapma ve planı uygulama aşamasında ise Atakan ve Emel iki problemde muhakeme yapma stratejisini kullanmışlardır. Örneğin Emel birinci problemde çizdiği tablo üzerinden çözümünü "O zaman A, B'nin 4 katı olacağı için 36:4=9 litre B bidonunun bir süre sonraki durumudur. Sonra 9, şimdi 3 ise 9$3=6$ litre su dolmuş. 36-6=30 litre A musluğu" şeklindeki muhakemesiyle açıklamıştır.

Ikinci problemde ise öğrenciler iki nicelik olarak "Veysel ve Hürriyet'in boyama hızlarını" ve "Veysel'in Hürriyet'ten daha hızlı" olduğunu düşünmüşler ve niceliklerin birbirlerine göre değiş̧imlerini göz önüne alarak, boyama hızlarını karşılaştırmış ve nicelikler arası çarpımsal ilişkiyi keşfetmişlerdir. Bu süreci Emel diyagram, Atakan ise tablo çizerek göstermiştir. 
Tanışlı \& Dur - Çukurova Üniversitesi Eğitim Fakültesi Dergisi, 47(1), 2018, 60-108

Plan yapma ve planı uygulama aşamasında ise iki öğrenci de muhakeme yapma stratejisini kullanmışlardır. Örneğin Emel problemi çizdiği diyagram üzerinden çözümünü "Veysel Hürriyet'ten daha hızlı. Veysel'in Hürriyet'e zaman oranı 4/5. Hız oranı da bunun tam tersi olacak 5/4. Hürriyet 4/4 hızla 2 gün önce başlıyorsa Veysel $1 / 4$ lük hızla bu farkı kapatacak. Veysel yaparken Hürriyet de yaptığı için Hürriyet 4/4 hızla Veysel 5/4 hızla aradaki fark $1 / 4$ olduğu için Veysel 1/4 hızla çalışıyor gibi görünür." şeklinde muhakemesiyle açıklama yapmıştır.

Atakan ise problemi Şekil 22'deki gibi, çizdiği tablo üzerinden çözmüş ve çözümünü de "Veysel $1 / 5$ daha kısa sürede boyar. Hızları zamanın tam tersi olması gerekir. Çünkü Veysel süreyi daha iyi kullanıyor. Aynı paydada yazdığımız için Hürriyet'in hızı 4/4 Veysel'in hızı 5/4 olur. Aralarında 1/4'lük bir fark var. Hürriyet 4/4 lük hızıyla 2 gün önce başlamış. Her bir 1/4 lük kısma 2 dersem 4/4 lük kısım 8 günde tamamlanır"şeklinde açıklamıştır.

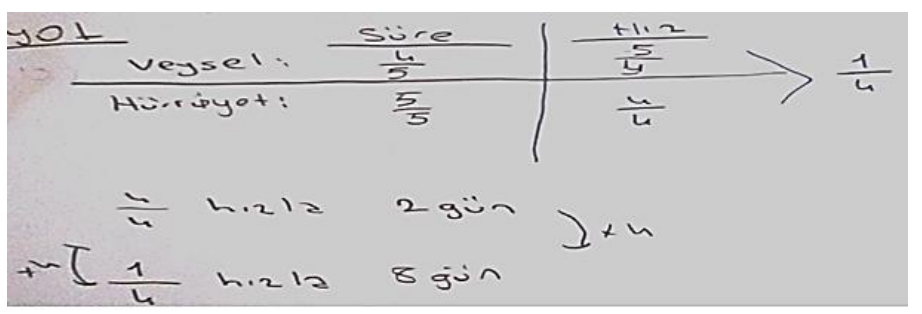

Şekil 22. Atakan'ın çözümü

Değerlendirme aşamasında ise iki öğrenci sonuçların doğruluğunu kontrol etmiş ve çözümü yorumlamışlardır.

\section{Tartışma ve Sonuç}

Ortaokul altıncı sınıf öğrencileri üzerinde gerçekleştirilen ancak iki odak öğrencinin klinik görüşmelerinin ortaya konulduğu bu araştırma ile nicel muhakeme gelişiminin problem çözme becerisindeki rolü belirlenmeye çalışılmıştır. Araştırmanın sonunda ise iki önemli durum ortaya çıkmıştır. Birincisi Thompson (1993)'nın iddiası ve bazı araştırmalarda da gözlendiği gibi (Ellis, 2007; Moore, 2010; Smith \& Thompson, 2007;) nicel muhakemenin gelişimi üzerine yapılacak bir öğretimle öğrencilerinin bu becerilerinin gelişebildiği diğeri ise bu gelişimle birlikte problem çözme becerilerinin gelişiminin de sağlanabildiğidir (Moore, Carlson ve Oehrtman, 2009; Moore ve Carlson, 2012). Öğretim öncesi ve sonrası öğrencilerin ortaya koydukları zihinsel eylemler karşılaştırıldığında bu gelişimin sağlandığını ortaya koyan pek çok delile rastlanmaktadır. Araştırmada öğrencilere dört farklı türde ve her türe ait üç karmaşıklık düzeyinde gerçek yaşam problemleri sunulmuştur. Öğretim öncesi her problem türünden genellikle basit karmaşık düzeye sahip problemler çözülebilmiş, orta ve yüksek karmaşıklık düzeyindeki problemlerin çözümünde zorlanılmıştır. Çözümü yapılan problemlerde "yanıt" genelde aritmetik ya da cebirsel hesaplamaların sonucu ile bulunabildiği için öğrenciler bu problemlerde zorlanmamışlardır. Çözümlerinde ise genelde problemde kullanılacak sayılara odaklanmışlar ve gerekli aritmetik işlemleri seçerek daha çok sınırlı stratejiler kullanmışlardır. Ancak aynı problem nicel ilişkiler yönünden değerlendirilmesi, diğer bir değişle sayılar ikinci plana atılıp önce niceliklere ve onlar arasındaki ilişkilere odaklanılması gereken bir duruma getirildiğinde ise öğrenciler bilişsel güçlük yaşamışlardır (Thompson, 1993). Matematikte anlam ve amaç kaybolduktan sonra öğrenciler için anlamsız düşünme tarzları ortaya çıktığı için (Smith \& Thompson, 2007) öğrenciler de bu karmaşıklık durumuyla başa çıkamamışlar çoğunlukla deneme yanılma stratejisini kullanmışlar ve kimi zamanda anlamsız işlemler gerçekleştirmiştir. Sowder (1988) öğrencilerin problem durumlarında niceliklere ve ilişkilere dikkat etmediklerinde çözümlerinde sayıların ve işlemlerin seçimi ile ilgili temelsiz, anlamsız tartışmalara girdiklerini ifade etmektedir. Dolayısıyla araştırmada da öğrencilerin ortaya koydukları bu durum problemlere ilişkin sayısal olmayan çıkarımda bulunamadıklarının diğer bir değişle, niceliklerin farkında olmadıklarının ve nicel ilişkilere ilişkin çıkarımda bulunamadıklarının bir göstergesi olmuştur (Thompson, 1993). Bu sonuç bazı araştırma bulgularıyla da paralellik göstermektedir (Kabael \& Akın, 2016). Bu noktada öğrencilerin genellikle tek tip sonuca götüren problem durumlarıyla daha fazla karşılaşmaları 
onların bu tür problemlerde zorlanmalarının bir diğer nedeni olabileceği söylenebilir. Nitekim öğrencilerin günlüklerine yazdıkları ifadelerden bu durum göze çarpmaktadır. Örneğin Atakan verilen problemi çözerken zorlandığını ve bu tür bir problem ile daha önce karşılaşmadığını Şekil 25'teki gibi açıklamıştır.

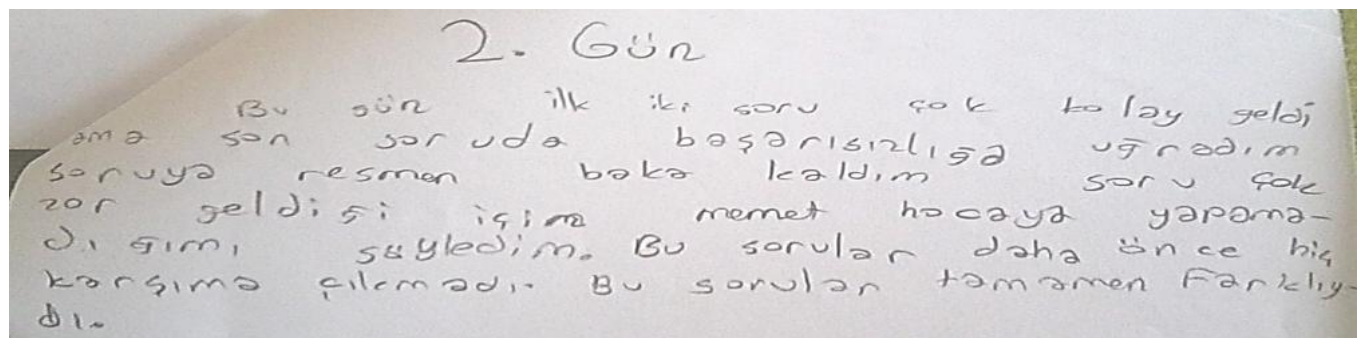

Şekil 25. Atakan'ın günlüğü

Öğretim süreci sonunda yapılan görüşmelerle öğrencilerde gözlenen değişimler, nicelikler ve nicelikler arası ilişkiler üzerine düşünme yaklaşımının problem çözme sürecinin odağı olabileceği düşüncesini doğurmuştur. Çünkü nicel muhakemenin gelişimine odaklı yapılan öğretimler öğrencilerin problem çözme becerilerinde büyük bir değişim yaratmıştır. Öncelikle her düzey problem birden fazla yolla ve uygun stratejiler kullanılarak başarıyla çözülmüştür. En önemli gelişme ise özellikle görsel temsil (diyagram) kullanımda gerçekleşmiştir. Pek çok çalışmada da vurgulandığı gibi (Diezmann, \& English, 2001; Jonassen, 2003; Smith \& Thompson, 2007; Thompson, 2011), problemi anlama ve çözme aşamasında kullanılan görsel temsiller nicelikleri ve nicel ilişkileri göstermede önemli araçlardır. Araştırmada öğretim sürecinde kullanılan bu araçlar öğrencilerin problemlerde verilen bilgiler arasından niceliklere odaklanmalarını ve nicel ilişkileri yorumlamalarını aynı zamanda Koedinger ve Nathan (2004)'ın da ifade ettikleri gibi farklı çözümler gerçekleştirmelerini sağlamış ve bunun delili son görüşmelerde gözlenmiştir. Öğretim öncesi öğrencilerin problem çözümlerinde görsel temsil kullanmamaları Bednarz, Radford, Janvier ve Lepage'in (1992) çalışmalarında belirttikleri “aritmetikten cebire geçişteki bütün güçlükler problemlerin temsilsel olarak yapılandırılamamasından kaynaklanmaktadıı" düşüncesini desteklemektedir. Benzer şekilde Smith ve Thompson (2007)'da öğrencilerin bir problem durumunu tanımlarken kullandıkları sözel ifadeler açıklığını kaybettiğinde bu tanımlamalarını diyagramlarla daha rahat ifade ettiklerini belirtmişlerdir. Öğrencilerin problem çözümlerinde başarılı olmalarının altında yatan nedenin Smith ve Thompson (2007)'da iddia ettiği gibi, nicel muhakeme becerilerinin gelişmesi olduğunu söyleyebiliriz. Çünkü bu süreçte öğrenciler problem durumlarında sayısal bilgiden bağımsız olarak nicelikler ve nicelikler arası ilişkilere odaklandıkları için problemleri daha iyi anlamlandırmışlardır. Aynı zamanda nicel işlemler ile aritmetik işlemleri ayırt edebilmişlerdir. Bu sonuç Kabael ve Akın (2016) tarafından yapılan çalışmada da, nicel muhakeme becerilerini etkili şekilde kullanan öğrencilerin problemleri daha iyi anlamlandırıp kısa zamanda çözebilmeleri ve nicel muhakeme becerisi yardımıyla cebirsel stratejileri etkili bir şekilde kullanabilmeleri, problem çözme sürecinde daha esnek yaklaşımlar ve zaman tasarrufu yapabilmeleri sonucuyla paralellik göstermektedir.

Araştırma sonuçları öğretim planlanırken ele alınan karmaşık problem durumlarının nicel muhakeme gelişiminde fark yarattığını göstermiştir. Dolayısıyla öğrencileri sayılardan bağımsız düşünmeye sevk eden nicel ilişkiler yönünden zengin problem durumlarıyla karşılaştırmak önemlidir. Sonuçtan ziyade düşünme sürecinin önemi göz önüne alındığında öğrencilerin düşüncelerini rahatça ifade edebilecekleri bir sınıf ortamı sağlanmalı ve öğrencilerin "burada ne oluyor?" tartışmasını yapmasına olanak tanınmalıdır. Problem çözümlerinde anahtar kelimelerden (daha fazla, kat vb.) önce problemde öğrencilerin niceliklere odaklanmaları ve niceliği, nicel ilişkileri tanımlamaları sağlanmalıdır. Bu süreçte öğrenciler diyagram, tablo, şekil gibi görsel temsil kullanmaya teşvik edilmelidir. Ortaokul altıncı sınıf öğrencileri üzerinde gerçekleştirilen bu çalışma daha farklı tasarımlarla ilkokul, lise ya da öğretmen adayları üzerinde de gerçekleştirilerek alana farklı yönlerden önemli katkılar getirilebilir. Ayrıca ders 
Tanışlı \& Dur - Çukurova Üniversitesi Eğitim Fakültesi Dergisi, 47(1), 2018, 60-108

kitaplarının öğrenme ve öğretme sürecindeki rolü dikkate alındığında ders kitaplarının nicel muhakeme becerisini destekleyip desteklemediğine ilişkin araştırma da yapılabilir. 
Tanışlı \& Dur - Çukurova Üniversitesi Eğitim Fakültesi Dergisi, 47(1), 2018, 60-108

\section{References}

Bayazıt, i. (2013). An investigation of problem solving approaches, strategies, and models used by the 7th and 8th grade students when solving real-world problems. Educational Sciences: Theory \& Practice, 13(3), 1903-1927.

Bednarz, N., Radford, L., Janvier, B. \& Lepage, A. (1992). Arithmetic and algebraic thinking in problemsolving. In W. Geeslin \& Graham (Eds.), Proceedings of the 16th conference of the International Group for the Psychology of Mathematics Education (Vol. 1, pp. 65-72). Durham, New Hampshire: program Committee.

Blanton, M. L. (2008). Algebra and the elementary classroom: Transforming thinking, transforming practice. Heinemann, $\mathrm{NH}$.

Cai, J., Ng, S. F., \& Moyer, J. C. (2011). Developing students' algebraic thinking in earlier grades: Lessons from China and Singapore. In J. Cai ve E. Knuth (Eds.), Early algebraization: A global dialogue from multiple perspectives. (pp. 25-41). Springer Berlin Heidelberg.

Çelik, D. \& Güler, M. (2003). Examination of Realistic Problem Solving Skills of Sixth Grade Students. Dicle University. Dicle University Ziya Gökalp Education Faculty Journal, 20, 180-195.

Common Core State Standards Initiative. (2010). Common Core State Standards for Mathematics (CCSSM). Washington, DC: National Governors Association Center for Best Practices and theCouncil of Chief State School Officers.

Clement, J. (2000). Analysis of clinical interviews: Foundations and model viability. In A. E. Kelly, \& R. A. Lesh (Eds.), Handbook of research design in mathematics and science education, (pp. 547-589). London: Lawrence Erlbaum Associates, Publishers.

Cobb, P., \& Steffe, L. P. (1983). The constructivist researcher as teacher and model builder. Journal for Research in Mathematics Education, 14(2), 83-94.

Diezmann, C., \& L. English. (2001). Promoting the use of diagrams as tools for thinking. In A.A. Cuoco and F. R. Curcio (Eds.), The role of representation in school mathematics. (pp.77-89). Reston, VA: National Council of Teachers of Mathematics.

Dwyer, C. A., Gallagher, A., Levin, J. \& Morley, M. E. (2003). What is quantitative reasoning? Defining the construct for assessment purposes. Research Report (RR-03-30), Education Testing Service.

Ellis, A. B. (2007). The influence of reasoning with emergent quantities on students' generalizations. Cognition and Instruction, 25(4), 439-478.

Herscovics N. \& Kieran C. (1980). Constructing meaning for the concept of equation. Mathematics Teacher, 80, 572-580.

Jonassen, D. (2003). Using cognitive tools to represent problems. Journal of Research on Technology in Education, 35(3), 362-381.

Kabael, T., \& Akın, A. (2016). Problem solving strategies and quantitative reasoning skills in solving algebraic verbal problems of seventh grade students. Kastamonu Education Journal, 24(2), 875-894.

Kamal, A. \& Ramzi, N. (2000). The role of presentation and response format in understanding, preconceptions and alternative concept in algebra word problems. ERIC Document Reproduction Service No. ED 438174.

Koedinger, K.R., \& Nathan, M.J. (2004). The real story behind story problems: Effects of representations on quantitative reasoning. The Journal of The Learning Sciences, 13(2), 129-164.

Liamputtong, P. (2009).Qualitative research methods, $3^{\text {rd }}$ edition. Melbourne: Oxford University Press. 
Tanışlı \& Dur - Çukurova Üniversitesi Eğitim Fakültesi Dergisi, 47(1), 2018, 60-108

Lochhead, J. (1988). Some Pieces of the Puzzle. In G. Forman \&P. Pufall., Hillsdale (Eds.), In constructivism in the computer age. (pp. 71-82 ). N.J.:Lawrence Erlbaum Associates.

Mayer, R. E., Lewis, A. B., \& Hegarty, M. (1992). Mathematical misunderstandings: Qualitative reasoning about quantitative problems. Advances in Psychology, 91, 137-153.

Ministry of National Education (2017). Mathematics curriculum (Primary and middle schools 1, 2, 3, 4, 5, 6,7 , and 8 classes). Ankara: MEB Publications.

Miles M., \& Huberman, M. (1994). An expanded sourcebook qualitative data analysis. Second Edition. California: Sage Publications.

Moore, K. C., Carlson, M. P., \& Oehrtman, M. (2009). The role of quantitative reasoning in solving applied precalculus problems. Paper presented at the Twelfth Annual Special Interest Group of the Mathematical Association of America on Research in Undergraduate Mathematics Education (SIGMAA on RUME) Conference, Raleigh, NC: North Carolina State University.

Moore, C.K. (2010). The role of quantitative reasoning in precalculus students learning central concepts of trigonometry. Unpublished doctoral dissertion, Arizona State University, ABD.

Moore, K. C., \& Carlson, M. P. (2012). Students' images of problem contexts when solving applied problems. The Journal of Mathematical Behavior, 31(1), 48-59.

National Council of Teachers of Mathematics (2000). Principles and standarts for school mathematics. Reston, Va.: NCTM.

Polya, G. (1945). How to solve it: a new aspect of mathematical method: a new aspect of mathematical method. Princeton university press.

Schoenfeld, A. H. (1985). Mathematical problem solving. Orlando, FL: Academic Press.

Stacey, K., \& MacGregor, M. (1999). Learning the algebraic method of solving problems. The Journal of Mathematical Behavior, 18(2), 149-167.

Smith, J., \& Thompson, P. (2007). Quantitative reasoning and the development of algebraic reasoning. In J. Kaput \& D. Carraher (Eds.), Algebra in the early grades (pp. 95-132). New York, NY: Lawrence Erlbaum Associates.

Sowder, L. (1988). Children's solutions of story problems. Journal of Mathematical Behavior, 7, 227-238.

Şener, Z.T. \& Bulut, N. (2015). The difficulties 8th graders experience in the process of problem solving in mathematics courses. Gazi University Gazi Education Faculty Journal, 35(3), 637-661.

Steffe, L. P. (1991). The constructivist teaching experiment: Illustrations and implications. In E. vonGlasersfeld (Ed.), Radical constructivism in mathematics education (pp. 177-194). Boston,MA: Kluwer Academic Press.

Tambychik, T. \& Meerah, T.S.M. (2010). Students' difficulties in mathematics problem-solving: What do they say?Procedia Social and Behavioral Sciences, 8, 142-151.

Thompson P. W. (1988). Quantitative concepts as a foundation for algebraic reasoning: sufficiency, necessity, and cognitive obstacles. M. Behr, C. Lacampagne \& M. Wheeler (Eds.), Proceedings of the Annual Conference of the International Group for the Psychology of Mathematics Education, 163170.

Thompson P. W. (1993). Quantitative reasoning, complexity, and additive structures. Educational Studies in Mathematics, 25 (3), 165-208.

Thompson P. W. (2011). Quantitative reasoning and mathematical modeling. L. L. Hatfield, S. Chamberlain \& S. Belbase (Eds.), New Perspectives and Directions for Collabrative Research in Mathematics Education.(pp. 33-57). Laramie, WY: University of Wyoming. 
Tanışlı \& Dur - Çukurova Üniversitesi Eğitim Fakültesi Dergisi, 47(1), 2018, 60-108

Türnüklü, E.B. \& Yeşildere, S. (2005). Problem, problem solving and critical thinking. Gazi University Gazi Education Faculty Journal, 25(3), 107-123.

Yıldırım, A. \& Simsek, H. (2011). Qualitative research methods in the social sciences. Ankara: Seckin Publisher.

Verschaffel, L., De Corte, E., \& Vierstraete, H. (1999). Upper elementary school pupils' difficulties in modeling and solving nonstandard additive word problems involving ordinal numbers. Journal for Research in Mathematics Education, 265-285.

Verschaffel, L., De Corte, E., Lasure, S., Vaerenbergh, G. V., Bogaerts, H., ve Ratinckx, E. (1999). Learning to solve mathematical application problems: a design experiment with fifth graders. Mathematical Thinking and Learning, 1(3), 195-229.

Van Amerom, B. (2002). Reinvention of early algebra: developmental research on the transition from arithmetic to algebra, Unpublished doctoral dissertion, University of Utrecht, The Netherlands.

Van De Walle,. J.,A., Karp, K. S., Bay-Williams, J.M. (2016). Elementary and middle school mathematics. Teaching developmentally. (Trans. Edit. Soner Durmuş), 7th Printing Translation. Nobel Publisher, Ankara. 